Prepared in cooperation with Colorado Springs City Engineering

\title{
Characterization of Water Quality and Suspended Sediment during Cold-Season Flows, Warm-Season Flows, and Stormflows in the Fountain and Monument Creek Watersheds, Colorado, 2007-2015
}

Scientific lnvestigations Report 2017-5084, 
Cover. Monument Creek near Pikeview Reservoir at Colorado Springs, Colo. (Photograph by Holly Fransua, U.S. Geological Survey). 


\section{Characterization of Water Quality and Suspended Sediment during Cold- Season Flows, Warm-Season Flows, and Stormflows in the Fountain and Monument Creek Watersheds, Colorado, 2007-2015}

By Lisa D. Miller and Robert W. Stogner, Sr.

Prepared in cooperation with Colorado Springs City Engineering

Scientific Investigations Report 2017-5084 


\title{
U.S. Department of the Interior \\ RYAN K. ZINKE, Secretary
}

\section{U.S. Geological Survey William H. Werkheiser, Acting Director}

\author{
U.S. Geological Survey, Reston, Virginia: 2017
}

For more information on the USGS - the Federal source for science about the Earth, its natural and living resources, natural hazards, and the environment-visit https://www.usgs.gov or call 1-888-ASK-USGS.

For an overview of USGS information products, including maps, imagery, and publications,

visit https://store.usgs.gov/.

Any use of trade, firm, or product names is for descriptive purposes only and does not imply endorsement by the U.S. Government.

Although this information product, for the most part, is in the public domain, it also may contain copyrighted materials as noted in the text. Permission to reproduce copyrighted items must be secured from the copyright owner.

Suggested citation:

Miller, L.D., and Stogner, R.W., Sr., 2017, Characterization of water quality and suspended sediment during cold-season flows, warm-season flows, and stormflows in the Fountain and Monument Creek Watersheds, Colorado, 2007-2015: U.S. Geological Survey Scientific Investigations Report 2017-5084, 47 p., https://doi.org/10.3133/sir20175084.

ISSN 2328-0328 (online) 


\section{Acknowledgments}

The authors appreciate the efforts of those who assisted in the collection of these data with thanks to Colorado Springs City Engineering staff for help with planning and support for the monitoring program.

\section{Contents}

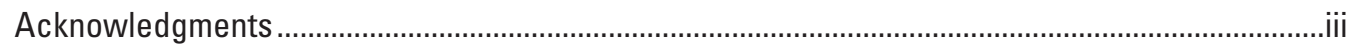

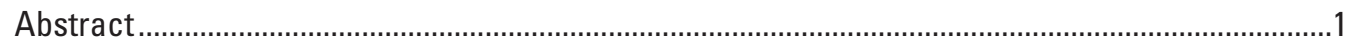

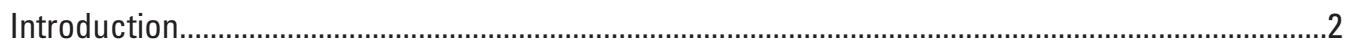

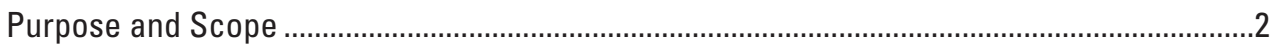

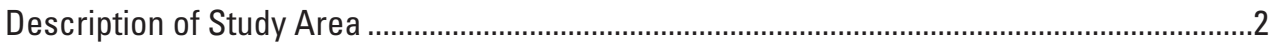

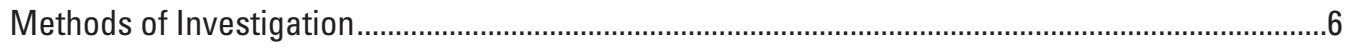

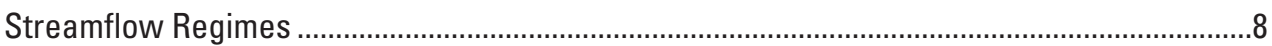

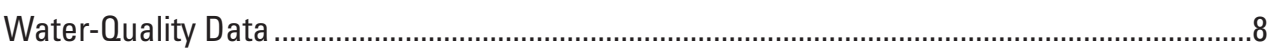

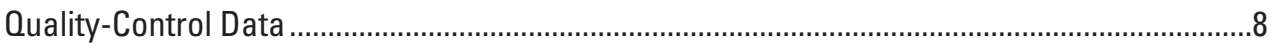

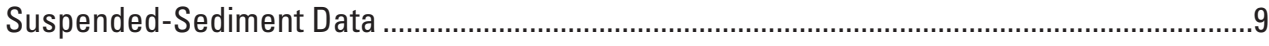

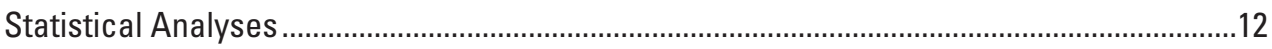

Water Quality and Suspended Sediment in the Fountain and Monument Creek Watersheds.......12

Upper Fountain Creek Watershed.....................................................................................13

Specific Conductance, pH, and Dissolved Oxygen .....................................................13

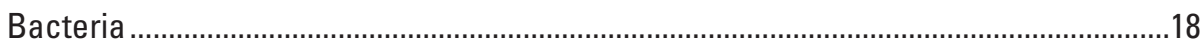

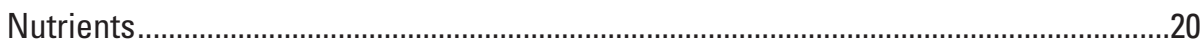

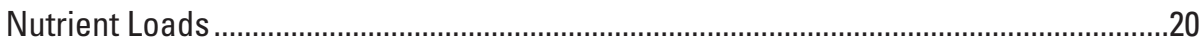

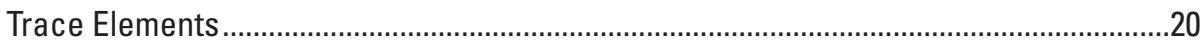

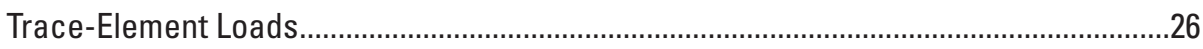

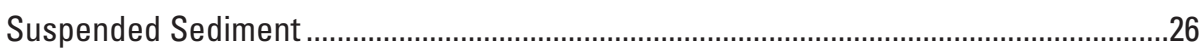

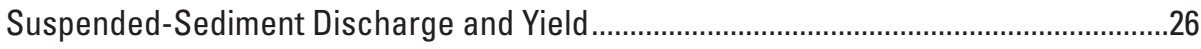

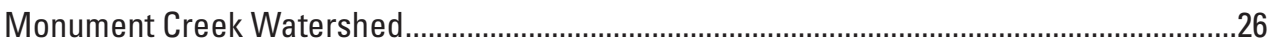

Specific Conductance, pH, and Dissolved Oxygen ...................................................36

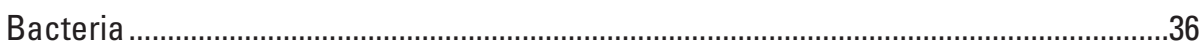

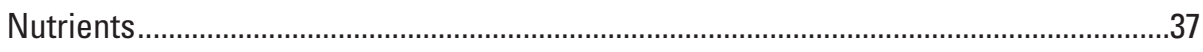

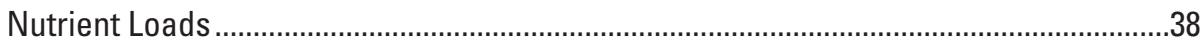

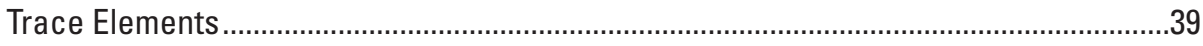

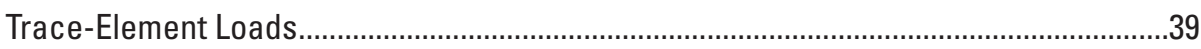

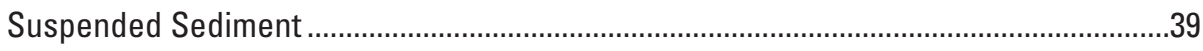

Suspended-Sediment Discharge and Yield.....................................................................

Lower Fountain Creek Watershed ..................................................................................... 40

Specific Conductance, $\mathrm{pH}$, and Dissolved Oxygen .......................................................40

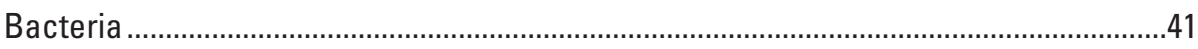

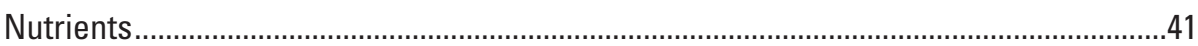


Nutrient Loads.

Trace Elements

Trace-Element Loads........................................................................................................ 42

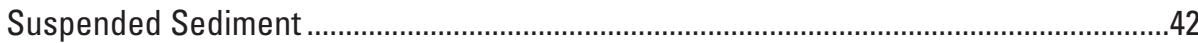

Suspended-Sediment Discharge and Yield....................................................................4

Summary

References Cited 46

\section{Figures}

1. Map showing location of study area and sampling sites for the Fountain and Monument Creek watersheds, Colorado....

2-12. Graphs showing:

2. Annual precipitation at the Colorado Springs Weather Service Office Colorado; $A, 1949$ through 2015 and $B, 2007$ through 2015

3. Annual hydrograph for site 07105800 , Fountain Creek at Security, depicting flow regimes

4. Variations in sampled streamflow at $A$, main-stem sites and $B$, tributary sites for cold-season flow, warm-season flow, and stormflow in Fountain and Monument Creek watersheds, Colorado, 2007 through 2015

5. Variations in specific conductance at $A$, main-stem sites and $B$, tributary sites for cold-season flow, warm-season flow, and stormflow in Fountain and Monument Creek watersheds, Colorado, 2007 through 2015

6. Variations in Escherichia coli (E. coli) for cold-season flow, warm-season flow, and stormflow at sites in Fountain and Monument Creek watersheds, Colorado, 2007 through 2015

7. Variations in $A$, dissolved ammonia, $B$, nitrate plus nitrite, and $C$, total phosphorus concentrations at sites for cold-season flow, warm-season flow, and stormflow in the Fountain and Monument Creek watersheds, Colorado, 2007 through 2015.

8. Variations in $A$, dissolved ammonia, $B$, dissolved nitrate plus nitrite, and $C$, total phosphorus loads at sites for cold-season flow, warm-season flow, and stormflow in the Fountain and Monument Creek watersheds, Colorado, 2007 through 2015.

9. Variations in $A$, total arsenic, $B$, dissolved boron, $C$, dissolved copper, $D$, total copper, $E$, total lead, and $F$, total manganese concentrations at sites for cold-season flow, warm-season flow, and stormflow in the Fountain and Monument Creek watersheds, Colorado, 2007 through 2015.

10. Variations in $A$, total nickel, $B$, dissolved selenium, $C$, total selenium, $D$, dissolved zinc, and $E$, total zinc concentrations at sites for cold-season flow, warm-season flow, and stormflow in the Fountain and Monument Creek watersheds, Colorado, 2007 through 2015

11. Variations in $A$, total arsenic, $B$, dissolved boron, $C$, dissolved copper, $D$, total copper, E, total lead, and F, total manganese loads at sites for cold-season flow, warm-season flow, and stormflow in the Fountain and Monument Creek watersheds, Colorado, 2007 through 2015

12. Variations in $A$, total nickel, $B$, dissolved selenium, $C$, total selenium, $D$, dissolved zinc, and $E$, total zinc loads at sites for cold-season flow, warm-season flow, and stormflow in the Fountain and Monument Creek watersheds, Colorado, 2007 through 2015 


\section{Tables}

1. Selected surface-water sites in the Fountain and Monument Creek watersheds, Colorado, and water-quality constituents, suspended-sediment and biological parameters measured or analyzed, 2007 through 2015 ...................................................

2. Population totals for El Paso County and Colorado Springs, Colorado, 1870-2015 ..........6

3. Field blank values, Fountain Creek watershed, Colorado, 2007-2015 ............................10

4. Minimum, median, and maximum values for selected field parameters and discharge at sites in the Fountain Creek watershed, Colorado, 2007 through 2015........14

5. Minimum, median, and maximum Escherichia coli and suspended-sediment concentrations in cold-season flow, warm-season flow, and stormflow samples at selected sites in the Fountain Creek watershed, Colorado, 2007-2015.

6. Instantaneous flow and Escherichia coli concentrations at dry weather sites in the Fountain Creek watershed, Colorado, during 2015

7. Minimum, median, and maximum concentrations for ammonia, nitrate plus nitrite, and phosphorus at sites in the Fountain Creek watershed, Colorado, 2007-2015...........22

8. Minimum, median, and maximum concentrations for selected trace elements at sites in the Fountain Creek watershed, Colorado, 2007-2015

9. Median suspended-sediment concentrations during cold-season flow, warm-season flow, and stormflow in the Fountain and Monument Creek watersheds, Colorado, and $p$-values of Mann-Whitney test of significance of spatial variations in suspended-sediment concentrations

10. Median suspended-sediment discharge during cold-season flow, warm-season flow, and stormflow in the Fountain and Monument Creek watersheds, Colorado, and $p$-values of Mann-Whitney test of significance of spatial variations in suspended-sediment discharges.

11. Median suspended-sediment yield during cold-season, warm-season flow, and stormflow in the Fountain and Monument Creek watersheds, Colorado, and $p$-values of Mann-Whitney test of significance of spatial variations in suspended-sediment yields. 


\section{Conversion Factors}

U.S. customary units to International System of Units

\begin{tabular}{|c|c|c|}
\hline Multiply & By & To obtain \\
\hline \multicolumn{3}{|c|}{ Length } \\
\hline foot $(\mathrm{ft})$ & 0.3048 & meter $(\mathrm{m})$ \\
\hline mile (mi) & 1.609 & kilometer $(\mathrm{km})$ \\
\hline \multicolumn{3}{|c|}{ Area } \\
\hline acre & 4,047 & square meter $\left(\mathrm{m}^{2}\right)$ \\
\hline square foot $\left(\mathrm{ft}^{2}\right)$ & 0.09290 & square meter $\left(\mathrm{m}^{2}\right)$ \\
\hline square mile $\left(\mathrm{mi}^{2}\right)$ & 259.0 & hectare (ha) \\
\hline square mile $\left(\mathrm{mi}^{2}\right)$ & 2.590 & square kilometer $\left(\mathrm{km}^{2}\right)$ \\
\hline \multicolumn{3}{|c|}{ Volume } \\
\hline ounce (oz) & 29.5735 & milliliter $(\mathrm{mL})$ \\
\hline gallon (gal) & 3.785 & liter (L) \\
\hline gallon (gal) & 0.003785 & cubic meter $\left(\mathrm{m}^{3}\right)$ \\
\hline cubic foot $\left(\mathrm{ft}^{3}\right)$ & 0.02832 & cubic meter $\left(\mathrm{m}^{3}\right)$ \\
\hline acre-foot (acre-ft) & 1,233 & cubic meter $\left(\mathrm{m}^{3}\right)$ \\
\hline \multicolumn{3}{|c|}{ Flow rate } \\
\hline cubic foot per second $\left(\mathrm{ft}^{3} / \mathrm{s}\right)$ & 0.02832 & cubic meter per second $\left(\mathrm{m}^{3} / \mathrm{s}\right)$ \\
\hline \multicolumn{3}{|c|}{ Mass } \\
\hline pound, avoirdupois (lb) & 0.4536 & kilogram (kg) \\
\hline ton, short $(2,000 \mathrm{lb})$ & 0.9072 & metric ton $(\mathrm{t})$ \\
\hline ton, long $(2,240 \mathrm{lb})$ & 1.016 & metric ton $(\mathrm{t})$ \\
\hline
\end{tabular}

Temperature in degrees Celsius $\left({ }^{\circ} \mathrm{C}\right)$ may be converted to degrees Fahrenheit $\left({ }^{\circ} \mathrm{F}\right)$ as follows:

$$
{ }^{\circ} \mathrm{F}=\left(1.8 \times{ }^{\circ} \mathrm{C}\right)+32 .
$$

Temperature in degrees Fahrenheit $\left({ }^{\circ} \mathrm{F}\right)$ may be converted to degrees Celsius $\left({ }^{\circ} \mathrm{C}\right)$ as follows:

$$
{ }^{\circ} \mathrm{C}=\left({ }^{\circ} \mathrm{F}-32\right) / 1.8 \text {. }
$$

\section{Datum}

Vertical coordinate information is referenced to the North American Vertical Datum of 1988 (NAVD 88).

Horizontal coordinate information is referenced to the North American Datum of 1983 (NAD 83). Altitude, as used in this report, refers to distance above the vertical datum. 


\title{
Supplemental Information
}

Specific conductance is given in microsiemens per centimeter at 25 degrees Celsius $(\mu \mathrm{S} / \mathrm{cm}$ at $\left.25^{\circ} \mathrm{C}\right)$.

Concentrations of chemical constituents in water are given in either milligrams per liter (mg/L) or micrograms per liter $(\mu \mathrm{g} / \mathrm{L})$.

\section{Abbreviation and Acronyms Used in This Report}

\author{
CDPHE Colorado Department of Public Health and Environment \\ $\mathrm{col} / 100 \mathrm{~mL}$ colonies per 100 milliliters \\ EPA U.S. Environmental Protection Agency \\ E. coli Escherichia coli \\ $\mathrm{ft} \quad$ feet \\ $\mathrm{ft}^{3} \quad$ cubic feet per second \\ GCLAS Graphical Constituent Loading Analysis System \\ IQR Interquartile Range \\ $\mathrm{lb} / \mathrm{d} \quad$ pounds per day \\ LRL laboratory reporting level \\ LT-MDL long-term method detection level \\ $\mathrm{mg} / \mathrm{L} \quad$ milligrams per liter \\ $\mu \mathrm{g} / \mathrm{L} \quad$ micrograms per liter \\ $\mu \mathrm{S} / \mathrm{cm} \quad$ microsiemens per centimeter at 25 degrees Celsius \\ $\mathrm{mm} \quad$ millimeter \\ $\mathrm{mL} \quad$ milliliter \\ $\mathrm{mi}^{2} \quad$ square mile \\ NWQL National Water Quality Laboratory \\ NWIS National Water Information System \\ tons/d tons per day \\ tons $/ \mathrm{d} / \mathrm{mi}^{2}$ tons per day per square mile \\ USGS U.S. Geological Survey
}





\title{
Characterization of Water Quality and Suspended Sediment during Cold-Season Flows, Warm-Season Flows, and Stormflows in the Fountain and Monument Creek Watersheds, Colorado, 2007-2015
}

\author{
By Lisa D. Miller and Robert W. Stogner, Sr.
}

\section{Abstract}

From 2007 through 2015, the U.S. Geological Survey, in cooperation with Colorado Springs City Engineering, conducted a study in the Fountain and Monument Creek watersheds, Colorado, to characterize surface-water quality and suspendedsediment conditions for three different streamflow regimes, with an emphasis on characterizing water quality during storm runoff. Data collected during this study were used to evaluate the effects of stormflows and wastewater-treatment effluent discharge on Fountain and Monument Creeks in the Colorado Springs, Colorado, area. Water-quality samples were collected at 2 sites on Upper Fountain Creek, 2 sites on Monument Creek, 3 sites on Lower Fountain Creek, and 13 tributary sites during 3 flow regimes: cold-season flow (November-April), warmseason flow (May-October), and stormflow from 2007 through 2015. During 2015, additional samples were collected and analyzed for Escherichia coli (E. coli) during dry weather conditions at 41 sites, located in $E$. coli impaired stream reaches, to help identify source areas and scope of the impairment.

Concentrations of E. coli, total arsenic, and dissolved copper, selenium, and zinc in surface-water samples were compared to Colorado in-stream standards. Stormflow concentrations of $E$. coli frequently exceeded the recreational use standard of 126 colonies per 100 milliliters at main-stem and tributary sites by more than an order of magnitude. Even though median $E$. coli concentrations in warm-season flow samples were lower than median concentrations in stormflow samples, the water-quality standard for $E$. coli was still exceeded at most main-stem sites and many tributary sites during warm-season flows. Six samples (three warm-season flow and three stormflow samples) collected from Upper Fountain Creek, upstream from the confluence of Monument Creek, and two stormflow samples collected from Lower Fountain Creek, downstream from the confluence with Monument Creek, exceeded the acute water-quality standard for total arsenic of 50 micrograms per liter. All concentrations of dissolved copper, selenium, and zinc measured in samples were below the water-quality standard.
Concentrations of dissolved nitrate plus nitrite generally increased from upstream to downstream during all flow periods. The largest downstream increase in dissolved nitrate plus nitrite concentration was measured between sites 07103970 and 07104905 on Monument Creek. All but one tributary that drain into Monument Creek between the two sites had higher median nitrate plus nitrite concentrations than the nearest upstream site on Monument Creek, site 07103970 (MoCr_Woodmen). Increases in the concentration of dissolved nitrate plus nitrite were also evident below wastewater treatment plants located on Fountain Creek.

Most stormflow concentrations of dissolved trace elements were smaller than concentrations from cold-season flow or warm-season samples. However, median concentrations of total arsenic, lead, manganese, nickel, and zinc generally were much larger during periods of stormflow than during cold-season flow or warm-season flow. Median concentrations of total arsenic, total copper, total lead, dissolved and total manganese, total nickel, dissolved and total selenium, and dissolved and total zinc concentrations increased from 1.5 to 28.5 times from site 07103700 (FoCr_Manitou) to 07103707 (FoCr_8th) during cold-season and warm-season flows, indicating a large source of trace elements between these two sites. Both of these sites are located on Fountain Creek, upstream from the confluence with Monument Creek.

Median suspended-sediment concentrations and median suspended-sediment loads increased in the downstream direction during all streamflow regimes between Monument Creek sites 07103970 (MoCr_Woodmen) and 07104905 (MoCr_Bijou); however, statistically significant increases ( $p$-value less than 0.05 ) were only present during warm-season flow and stormflow. Significant increases in median suspendedsediment concentrations were measured during cold-season flow and warm-season flow between Upper Fountain Creek site 07103707 (FoCr_8th) and Lower Fountain Creek site 07105500 (FoCr_Nevada) because of inflows from Monument Creek with higher suspended-sediment concentrations. Median suspendedsediment concentrations between sites 07104905 (MoCr_Bijou) and 07105500 (FoCr_Nevada) increased significantly during 
warm-season flow but showed no significant differences during cold-season flow and stormflow. Significant decreases in median suspended-sediment concentrations were measured between sites 07105500 (FoCr_Nevada) and 07105530 (FoCr_Janitell) during all flow regimes.

Suspended-sediment concentrations, discharges, and yields associated with stormflow were significantly larger than those associated with warm-season flow. Although large spatial variations in suspended-sediment yields occurred during warm-season flows, the suspended-sediment yields associated with stormflow were as much as 1,000 times larger than the suspended-sediment yields that occurred during warm-season flow.

\section{Introduction}

Fountain Creek is a tributary of the Arkansas River, draining a 926-square mile $\left(\mathrm{mi}^{2}\right)$ area that includes portions of El Paso, Teller, and Pueblo Counties in Colorado. Monument Creek is a major tributary to Fountain Creek, draining $235 \mathrm{mi}^{2}$. The population of the metropolitan area in and around Colorado Springs within the Fountain Creek watershed increased rapidly between 1940 and 2015 (Colorado Department of Local Affairs, $2017 \mathrm{a}, \mathrm{b}, \mathrm{c})$. Considerable changes in land use and water use have occurred during this time. Land use has changed from rangeland and forest use to urban and municipal use in many areas. Groundwater and surface-water withdrawals within the Fountain Creek watershed have also increased, and water is imported from outside of the watershed to meet the needs of the growing population. As the population has increased, the volume of treated municipal wastewater return flows discharged to Fountain and Monument Creeks has increased, and the number of onsite wastewater treatment systems has increased. In 2017, El Paso County Public Health estimated that there are about 30,000 onsite wastewater treatment systems operating in El Paso County (El Paso County Public Health, 2017). Waterquality information is needed to evaluate stream health related to changes in land use and water use and to meet regulatory requirements for storm water discharge within the Fountain Creek watershed.

From 2007 through 2015, the U.S. Geological Survey, in cooperation with Colorado Springs City Engineering, conducted a study within the Fountain and Monument Creek watersheds (fig. 1; table 1) to characterize surface-waterquality and suspended-sediment conditions in the watershed for three different streamflow regimes, with an emphasis on characterizing water quality during storm runoff. The scope of the study also included evaluating spatial differences in water quality and suspended sediment, and to the extent possible, evaluating the effects of wastewater-treatment plant operations on water quality and suspended sediment.

\section{Purpose and Scope}

The purpose of this report is to characterize water quality and suspended sediment during three streamflow regimes, cold-season flows, warm-season flows, and stormflows within the Fountain and Monument Creek watersheds using data collected from 2007 through 2015. To characterize waterquality and suspended-sediment conditions in this report: (1) values of onsite measurements of specific conductance, $\mathrm{pH}$, and dissolved oxygen and concentrations of Escherichia coli (E. coli), dissolved nitrate plus nitrite, total phosphorus, ammonia, selected trace elements, and suspended sediment were compared spatially and in relation to streamflow conditions, (2) concentrations of selected constituents were compared to Colorado in-stream water-quality standards, and (3) water-quality loads were estimated and compared for selected constituents during warm-season flow and stormflow.

\section{Description of Study Area}

The study area drains about $500 \mathrm{mi}^{2}$ and encompasses most of the urbanized area within the Fountain and Monument Creek watersheds. Elevations in the study area range from 14,109 feet (ft) at the summit of Pikes Peak to 5,460 ft at the southern end of the study area. There are two major physiographic regions in the study area - the Front Range of the Southern Rocky Mountains and the Colorado Piedmont (Hansen and Crosby, 1982). The Front Range, which comprises about the western one-third of the study area, is underlain by granite. Soils in this area are well drained and lie on steep slopes (Larsen, 1981; von Guerard, 1989a). The Colorado Piedmont, which comprises the remaining eastern two-thirds of the area, abuts the base of the Rampart Range. Underlying the northern part of the Colorado Piedmont in the study area is the Denver Basin, a structural basin containing principal aquifers composed of sandstone, shale, and alluvial and wind lain deposits. Soils in this area generally are sandy and well drained with gentler slopes than in the Front Range (Larsen, 1981; von Guerard, 1989a). Underlying the southern part of the Colorado Piedmont in the study area is an outcrop of the Pierre Shale. The Pierre Shale is the confining unit separating the aquifers of the Denver Basin from the Niobrara Formation, part of the Dakota-Cheyenne Aquifer (Colorado Geological Survey, 2003). The soils and geology on the Colorado Piedmont are readily erodible, especially relative to the granitic rocks on the west side of the study area. More details of the soils and geology of the study area are contained in Larsen (1981), von Guerard (1989a), and Colorado Geological Survey (2003).

The population of El Paso County, which includes Colorado Springs, increased from about 75,000 people in 1950 to about 310,000 in 1980, and to about 515,000 in 2000 (table 2). The 2015 population was estimated to be about 675,000 . The rate of growth was about 8,000 people per year between 1950 and 1990. Between 1990 and 2000, the rate of growth increased to about 11,000 people per year. In recent 

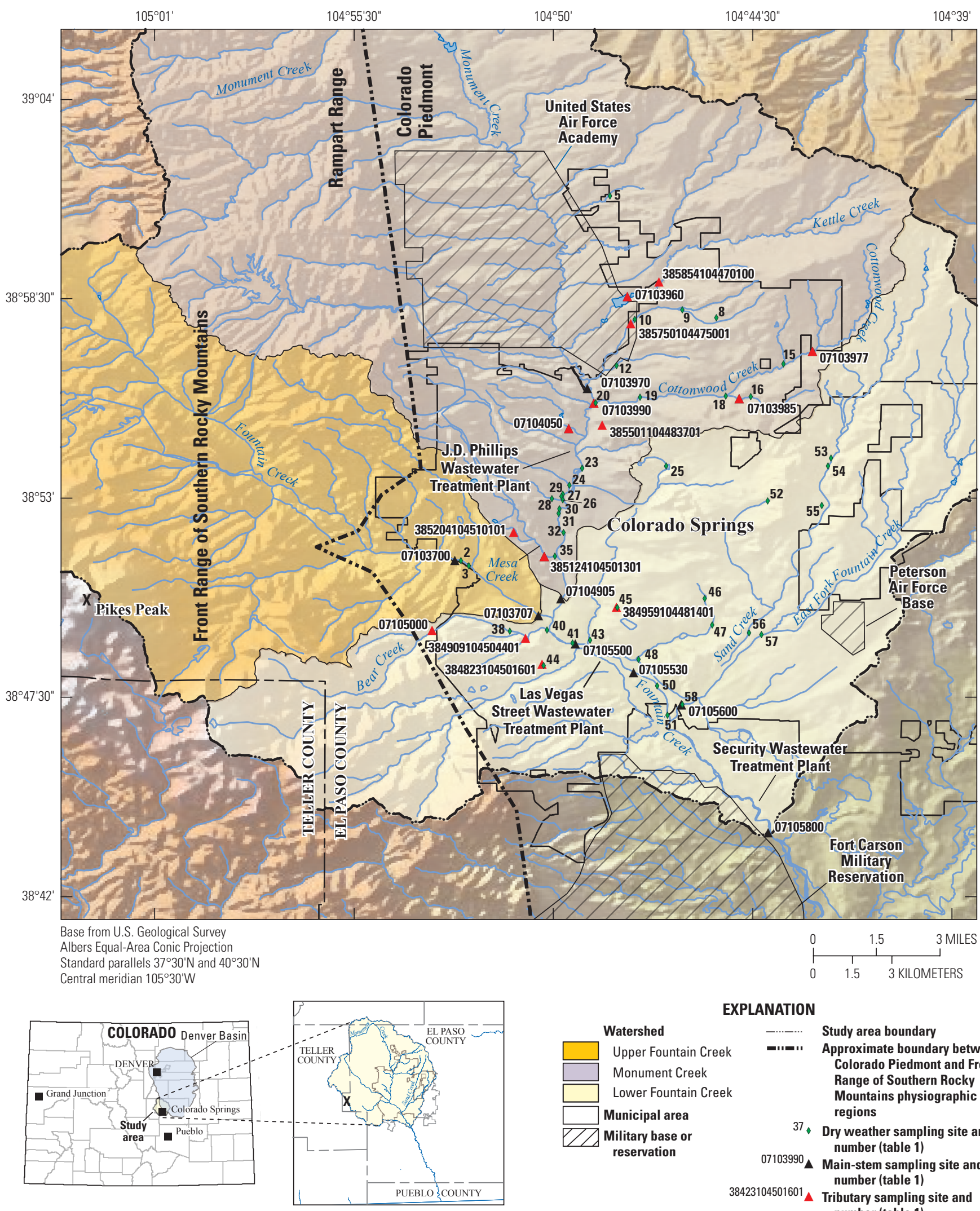

EXPLANATION

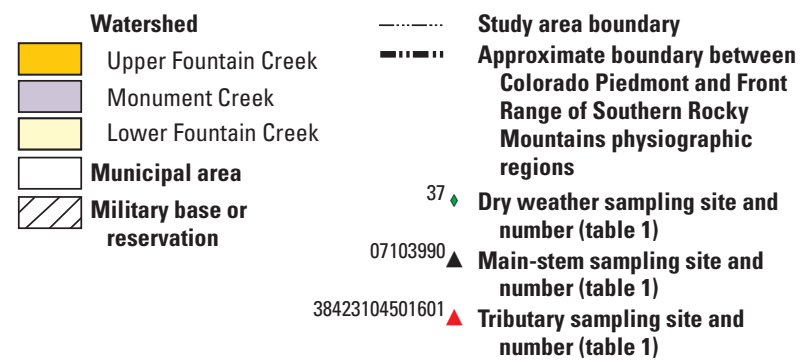

Figure 1. Location of study area and sampling sites for the Fountain and Monument Creek watersheds, Colorado. 
Table 1. Selected surface-water sites in the Fountain and Monument Creek watersheds, Colorado, and water-quality constituents, suspended-sediment and biological parameters measured or analyzed 2007 through 2015.

[WQ, water quality; E. coli, Escherichia coli; --, no value; USGS, U.S. Geological Survey]

\begin{tabular}{|c|c|c|c|c|c|c|c|c|c|c|}
\hline \multirow[b]{2}{*}{$\begin{array}{c}\text { USGS } \\
\text { site number }\end{array}$} & \multirow[b]{2}{*}{$\begin{array}{l}\text { Abbreviated } \\
\text { name }\end{array}$} & \multirow[b]{2}{*}{ USGS site name } & \multirow[b]{2}{*}{ Site type } & \multirow{2}{*}{$\begin{array}{c}\text { Dry } \\
\text { weather } \\
\text { site } \\
\text { number }\end{array}$} & \multirow[b]{2}{*}{ Network } & \multirow[b]{2}{*}{$\begin{array}{l}\text { Period } \\
\text { of data } \\
\text { collection }\end{array}$} & \multicolumn{3}{|c|}{ Water-quality constituents } & \multirow[b]{2}{*}{$\begin{array}{l}\text { Sedi- } \\
\text { ment }\end{array}$} \\
\hline & & & & & & & $\begin{array}{c}\text { Bacteria, } \\
\text { E. coli }\end{array}$ & $\begin{array}{c}\text { Nutri- } \\
\text { ents }\end{array}$ & $\begin{array}{c}\text { Trace } \\
\text { elements }\end{array}$ & \\
\hline \multicolumn{11}{|c|}{ Upper Fountain Creek } \\
\hline 07103700 & FoCr_Manitou & Fountain Creek near Colorado Springs, Colo. & Main stem & & WQ & $2007-2015$ & $\mathrm{X}$ & $\mathrm{X}$ & $\mathrm{X}$ & $\mathrm{X}$ \\
\hline 385116104523301 & & Fountain Creek at South 32nd Street near Colorado Springs (culvert) & Tributary & 2 & E. coli & 2015 & $\mathrm{X}$ & & & \\
\hline 385108104522001 & & Camp Creek at South 31st Street near Colorado Springs & Tributary & 3 & E. coli & 2015 & $\mathrm{X}$ & & & \\
\hline 07103707 & FoCr_8th & Fountain Creek below 8th Street, at Colorado Springs, Colo. & Main stem & & WQ & $2007-2015$ & $\mathrm{X}$ & $\mathrm{X}$ & $\mathrm{X}$ & $\mathrm{X}$ \\
\hline \multicolumn{11}{|c|}{ Monument Creek } \\
\hline 390121104482601 & & Monument Creek tributary near Diamond Rim Drive near Colorado Springs & Tributary & 5 & E. coli & 2015 & $\mathrm{X}$ & & & \\
\hline 385854104470100 & upper_Ke & Kettle Creek above Old Ranch Road near Colorado Springs, Colo. & Tributary & & WQ & $2007-2008$ & $\mathrm{X}$ & $\mathrm{X}$ & & \\
\hline 07103960 & lower_Ke & Kettle Creek above U.S. Air Force Academy, Colo. & Tributary & & WQ & 2007-2015 & $\mathrm{X}$ & $\mathrm{X}$ & $\mathrm{X}$ & $\mathrm{X}$ \\
\hline 385759104453001 & & Pine Creek drain at North Union Boulevard North Park at Colorado Springs & Tributary & 8 & E. coli & 2015 & $\mathrm{X}$ & & & \\
\hline 385812104462601 & & Pine Creek drain at Pine Creek Golf Club at Colorado Springs & Tributary & 9 & E. coli & 2015 & $\mathrm{X}$ & & & \\
\hline 385756104474501 & & Pine Creek drain Briargate Parkway at Colorado Springs (culvert) & Tributary & 10 & E. coli & 2015 & $\mathrm{X}$ & & & \\
\hline 385750104475001 & & Pine Creek above Highway 83 at Colorado Springs, Colo. & Tributary & & WQ & $2007-2008$ & $\mathrm{X}$ & $\mathrm{X}$ & & \\
\hline 385640104481501 & & South Pine Creek (culvert 2 aqueduct) at Goddard Street at Colorado Springs & Tributary & 12 & E. coli & 2015 & $\mathrm{X}$ & & & \\
\hline 07103970 & MoCr_Woodmen & Monument Creek above Woodmen Road at Colorado Springs, Colo. & Main stem & & WQ & 2007-2015 & $\mathrm{X}$ & $\mathrm{X}$ & $\mathrm{X}$ & $\mathrm{X}^{1}$ \\
\hline 07103977 & & Cottonwood Creek at Cowpoke Road at Colorado Springs, Colo. & Tributary & & WQ & 2007-2008 & $\mathrm{X}$ & $\mathrm{X}$ & & \\
\hline 385642104433901 & & Cottonwood Creek tributary at Potomac Drive at Colorado Springs & Tributary & 15 & E. coli & 2015 & $\mathrm{X}$ & & & \\
\hline 385548104443301 & & Cottonwood Creek drain at Austin Bluffs Parkway, Colorado Springs & Tributary & 16 & E. coli & 2015 & $\mathrm{X}$ & & & \\
\hline 07103985 & & Cottonwood Creek tributary above Rangewood Drive at Colorado Springs, Colo. & Tributary & & WQ & 2007-2008 & $\mathrm{X}$ & $\mathrm{X}$ & & \\
\hline 385549104451401 & & Cottonwood Creek drain Rangewood Drive at Colorado Springs & Tributary & 18 & E. coli & 2015 & $\mathrm{X}$ & & & \\
\hline 385547104473601 & & Cottonwood Creek drain at North Academy Boulevard near York Road & Tributary & 19 & E. coli & 2015 & $\mathrm{X}$ & & & \\
\hline 07103990 & lower_CoCr & Cottonwood Creek at mouth at Pikeview & Tributary & 20 & E. coli/WQ & $2007-2015$ & $\mathrm{X}$ & $\mathrm{X}$ & $\mathrm{X}$ & $\mathrm{X}^{1}$ \\
\hline 385501104483701 & & Monument Creek tributary 1 near Pulpit Rock at Colorado Springs, Colo. & Tributary & & WQ & 2007 & & $\mathrm{X}$ & & \\
\hline 07104050 & N. $\mathrm{RoCr}$ & North Rockrimmon Creek above Delmonico Drive at Colorado Springs, Colo. & Tributary & & WQ & $2007-2008$ & $\mathrm{X}$ & $\mathrm{X}$ & & \\
\hline 385349104491201 & & Monument Creek drain Pikeview Reservoir at Colorado Springs (culvert) & Tributary & 23 & E. coli & 2015 & $\mathrm{X}$ & & & \\
\hline 385321104493301 & & Douglas Creek at the mouth at Colorado Springs, Colo. & Tributary & 24 & E. coli & $2007-2015$ & $\mathrm{X}$ & & & \\
\hline 385353104465301 & & Templeton Gap floodway at North Union Boulevard at Colorado Springs & Tributary & 25 & E. coli & 2015 & $--^{2}$ & -- & -- & -- \\
\hline 385307104494401 & & Monument Creek drain 1 Mark Dabling Boulevard at Colorado Springs & Tributary & 26 & E. coli & 2015 & $\mathrm{X}$ & & & \\
\hline 385303104494601 & & Monument Creek drain 2 Mark Dabling Boulevard at Colorado Springs & Tributary & 27 & E. coli & 2015 & $\mathrm{X}$ & & & \\
\hline 385259104500201 & & Douglas Creek drain at Sinton Road at Colorado Springs (culvert) & Tributary & 28 & E. coli & 2015 & $\mathrm{X}$ & & & \\
\hline 385257104494401 & & Douglas Creek south at mouth at Colorado Springs, Colo. & Tributary & 29 & E. coli & 2015 & $\mathrm{X}$ & & & \\
\hline 385242104495001 & & Monument Creek drain 3 Mark Dabling Boulevard at Colorado Springs & Tributary & 30 & E. coli & 2015 & $\mathrm{X}$ & & & \\
\hline 385235104495101 & & Monument Creek drain 4 Mark Dabling Boulevard at Colorado Springs & Tributary & 31 & E. coli & 2015 & $\mathrm{X}$ & & & \\
\hline 385203104494301 & & Monument Creek aqueduct at Tremont Street at Colorado Springs & Tributary & 32 & E. coli & 2015 & $\mathrm{X}$ & & & \\
\hline 385204104510101 & & Monument Creek tributary 2 below Fillmore Street at Colorado Springs & Tributary & & WQ & 2007-2008 & $\mathrm{X}$ & $\mathrm{X}$ & & \\
\hline 385124104501301 & & Monument Creek tributary 2 at Sondermann Park at Colorado Springs & Tributary & & WQ & $2007-2015$ & $\mathrm{X}$ & $\mathrm{X}$ & $\mathrm{X}$ & $\mathrm{X}$ \\
\hline 385124104495701 & & Mesa Creek at mouth at Recreation Way at Colorado Springs & Tributary & 35 & E. coli & 2015 & $\mathrm{X}$ & & & \\
\hline 07104905 & MoCr Bijou & Monument Creek at Bijou Street at Colorado Springs, Colo. & Main stem & & WQ & $2007-2015$ & $X$ & $\mathrm{X}$ & $\mathrm{X}$ & $\mathrm{X}^{1}$ \\
\hline
\end{tabular}


Table 1. Selected surface-water sites in the Fountain and Monument Creek watersheds, Colorado, and water-quality constituents, suspended-sediment and biological parameters measured or analyzed 2007 through 2015.-Continued

[WQ, water quality; E. coli, Escherichia coli; --, no value; USGS, U.S. Geological Survey]

\begin{tabular}{|c|c|c|c|c|c|c|c|c|c|c|}
\hline \multirow[b]{2}{*}{$\begin{array}{c}\text { USGS } \\
\text { site number }\end{array}$} & \multirow[b]{2}{*}{$\begin{array}{c}\text { Abbreviated } \\
\text { name }\end{array}$} & \multirow[b]{2}{*}{ USGS site name } & \multirow[b]{2}{*}{ Site type } & \multirow{2}{*}{$\begin{array}{c}\text { Dry } \\
\text { weather } \\
\text { site } \\
\text { number }\end{array}$} & \multirow[b]{2}{*}{ Network } & \multirow[b]{2}{*}{$\begin{array}{c}\text { Period } \\
\text { of data } \\
\text { collection }\end{array}$} & \multicolumn{3}{|c|}{ Water-quality constituents } & \multirow[b]{2}{*}{$\begin{array}{l}\text { Sedi- } \\
\text { ment }\end{array}$} \\
\hline & & & & & & & $\begin{array}{c}\text { Bacteria, } \\
\text { E. coli }\end{array}$ & $\begin{array}{l}\text { Nutri- } \\
\text { ents }\end{array}$ & $\begin{array}{c}\text { Trace } \\
\text { elements }\end{array}$ & \\
\hline \multicolumn{11}{|c|}{ Lower Fountain Creek } \\
\hline 07105000 & FoCr Nevada & Bear Creek near Colorado Springs, Colo. & Tributary & & WQ & $2007-2008$ & $\mathrm{X}$ & $\mathrm{X}$ & & \\
\hline 384920104511201 & & Bear Creek drain near Creek Crossing Street at Colorado Springs & Tributary & 38 & E. coli & 2015 & $\mathrm{X}$ & & & \\
\hline 384909104504401 & & Bear Creek above 8th Street at Colorado Springs, Colo. & Tributary & & WQ & 2007-2014 & $\mathrm{X}$ & $\mathrm{X}$ & $\mathrm{X}$ & $\mathrm{X}$ \\
\hline 384921104501001 & & Bear Creek at Interstate 25 at Colorado Springs & Tributary & 40 & E. coli & 2015 & $\mathrm{X}$ & & & \\
\hline 384900104492801 & & Fountain Creek drain at South Tejon Street at Colorado Springs (culvert) & Tributary & 41 & E. coli & 2015 & $\mathrm{X}$ & & & \\
\hline 07105500 & & Fountain Creek at Colorado Springs, Colo. & Main stem & & WQ & $2007-2015$ & $\mathrm{X}$ & $\mathrm{X}$ & $\mathrm{X}$ & $\mathrm{X}^{1}$ \\
\hline 384905104485901 & & Shooks Run at Las Vegas Street at Colorado Springs & Tributary & 43 & E. coli & $2007-2015$ & $\mathrm{X}$ & & & \\
\hline 384823104501601 & & Cheyenne Run tributary at Colorado Springs (culvert) & Tributary & 44 & E. coli & 2015 & $\mathrm{X}$ & & & \\
\hline 384959104481401 & & Shooks Run tributary at Colorado Springs (culvert to ditch) & Tributary & 45 & E. coli & 2015 & $\mathrm{X}$ & & & \\
\hline 385014104454901 & & Spring Creek drain at Auburn Drive at Colorado Springs (culvert) & Tributary & 46 & E. coli & 2015 & $\mathrm{X}$ & & & \\
\hline 384930104453701 & & Spring Creek drain Majorie Lee Drive near Arpt Road at Colorado Springs & Tributary & 47 & E. coli & 2015 & $\mathrm{X}$ & & & \\
\hline 384833104473900 & & Spring Creek downstream Las Vegas Street & Tributary & 48 & E. coli & $2007-2015$ & $\mathrm{X}$ & & & \\
\hline 07105530 & FoCr_Janitell & Fountain Creek below Janitell Road below Colorado Springs, Colo. & Main stem & & WQ & $2007-2015$ & $\mathrm{X}$ & $\mathrm{X}$ & $\mathrm{X}$ & $\mathrm{X}^{1,3}$ \\
\hline 384749104470801 & & Fountain Creek drain near Circle Drive at Colorado Springs (culvert) & Tributary & 50 & E. coli & 2015 & $\mathrm{X}$ & & & \\
\hline 384701104465101 & & Unnamed ditch to Fountain Creek below I-25 at pond Colorado Springs & Tributary & 51 & E. coli & 2015 & $\mathrm{X}$ & & & \\
\hline 385255104440501 & & Valencia Creek near Oro Blanco Drive at Colorado Springs (culvert) & Tributary & 52 & E. coli & 2015 & $\mathrm{X}$ & & & \\
\hline 385406104422001 & & Sand Creek drain near Barnes Road at Colorado Springs (culvert) & Tributary & 53 & E. coli & 2015 & $\mathrm{X}$ & & & \\
\hline 385353104422501 & & Sand Creek drain at Barnes Road at Colorado Springs (culvert) & Tributary & 54 & E. coli & 2015 & $\mathrm{X}$ & & & \\
\hline 385248104423501 & & Sand Creek drain at Spring Ranch Golf Club at Colorado Springs & Tributary & 55 & E. coli & 2015 & $\mathrm{X}$ & & & \\
\hline 384917104443601 & & Sand Creek drain near Crestline Drive at Colorado Springs (culvert) & Tributary & 56 & E. coli & 2015 & $--^{2}$ & -- & -- & -- \\
\hline 384914104441501 & & Sand Creek drain at Nolte Drive west at Colorado Springs (culvert) & Tributary & 57 & E. coli & 2015 & $--^{2}$ & -- & -- & -- \\
\hline 07105600 & & Sand Creek above mouth at Colorado Springs & Tributary & 58 & E. coli/WQ & $2007-2015$ & $\mathrm{X}$ & $\mathrm{X}$ & $\mathrm{X}$ & $\mathrm{X}^{1}$ \\
\hline 07105800 & FoCr Security & Fountain Creek at Security, Colo. & Main stem & & WQ & 2007-2015 & $\mathrm{X}$ & $\mathrm{X}$ & $\mathrm{X}$ & $\mathrm{X}^{1}$ \\
\hline
\end{tabular}

'Daily suspended-sediment record.

${ }^{2}$ No flow during sampling period.

${ }^{3}$ Period of record for daily suspended sediment, 2013-2015. 
Table 2. Population totals for El Paso County and Colorado Springs, Colorado, 1870-2015.

[E, estimated; --, no value]

\begin{tabular}{cccc}
\hline Year & El Paso County & Year & Colorado Springs \\
\hline 1870 & ${ }^{1} 987$ & 1870 & -- \\
1880 & 17,949 & 1880 & ${ }^{1} 4,226$ \\
1890 & ${ }^{1} 21,239$ & 1890 & ${ }^{1} 11,140$ \\
1900 & ${ }^{1} 31,602$ & 1900 & ${ }^{1} 21,085$ \\
1910 & ${ }^{1} 43,321$ & 1910 & ${ }^{1} 29,078$ \\
1920 & 144,027 & 1920 & ${ }^{1} 30,105$ \\
1930 & 149,570 & 1930 & ${ }^{1} 33,237$ \\
1940 & ${ }^{1} 54,025$ & 1940 & ${ }^{1} 36,789$ \\
1950 & 174,523 & 1950 & ${ }^{1} 45,472$ \\
1960 & ${ }^{1} 143,742$ & 1960 & ${ }^{1} 70,194$ \\
1970 & ${ }^{1} 235,972$ & 1970 & ${ }^{1} 135,517$ \\
1980 & ${ }^{1} 309,424$ & 1980 & ${ }^{1} 215,105$ \\
1990 & ${ }^{1} 397,014$ & 1990 & ${ }^{1} 281,140$ \\
2000 & ${ }^{1} 516,929$ & 2000 & ${ }^{1} 360,890$ \\
2010 & ${ }^{1} 622,263$ & 2010 & ${ }^{1} 417,335$ \\
2015 & ${ }^{2} 677,022 \mathrm{E}$ & 2015 & ${ }^{3} 451,585 \mathrm{E}$ \\
\hline
\end{tabular}

${ }^{1}$ Colorado Department of Local Affairs, 2017a, Historical census dataCounties and municipalities: Colorado Department of Local Affairs web page accessed March 30, 2017, at https://demography.dola.colorado.gov/population/ data/historical_census/.

${ }^{2}$ Colorado Department of Local Affairs, 2017b, Population totals for Colorado and sub-state regions: Colorado Department of Local Affairs web page accessed March 30, 2017, at https://demography.dola.colorado.gov/ population/population-totals-colorado-substate/.

${ }^{3}$ Colorado Department of Local Affairs, 2017c, Population totals for Colorado municipalities: Colorado Department of Local Affairs web page accessed March 30, 2017, at https://demography.dola.colorado.gov/ population/population-totals-municipalities/.

years (2001-2015), the rate of growth remained about the same, 10,700 people per year (Colorado Department of Local Affairs, 2017a,b,c).

Annual precipitation in the Fountain and Monument Creek watersheds generally decreases as elevation decreases and decreases with distance from the headwaters of the watershed. The mean annual precipitation varies considerably from year to year (fig. 2). At the Colorado Springs Weather Service Office at Peterson Air Force Base (fig. 1), annual precipitation for 1949 through 2015 ranged from 7.8 to 27.6 inches (fig. 2A). Between 2007 and 2015, the annual precipitation ranged from 9.4 inches in 2010 to 25.2 inches in 2015 (fig. $2 B$ ). Much of the annual precipitation in the study area occurs from May through August (U.S. Climate Data, 2017).

\section{Methods of Investigation}

Water-quality samples were collected at 2 sites on Upper Fountain Creek, 2 sites on Monument Creek, 3 sites on Lower Fountain Creek, and 13 tributary sites under various streamflow conditions between 2007 and 2015 (table 1; fig. 1). Tributaries sampled included Kettle Creek, Cottonwood Creek, Mesa Creek, Bear Creek, and Sand Creek. Water-quality samples were classified into two groups: routine and storm. Routine samples were further classified as warm season or cold season as described below. At main-stem sites, routine water-quality samples were collected in February, May, July, and October at scheduled times with little regard for hydrologic conditions. Storm samples specifically targeted conditions during stormflow. Stormflow is defined as flow that is twice the base flow as calculated during winter months (cold season) on main-stem sites and three times the base flow as calculated during winter months on tributary sites. Stormflow samples were collected annually between April 1 and September 30 at main-stem sites. At tributary sites, routine water-quality samples were collected in June and October during warm-season flow and one storm sample was collected between April 1 and September 30. The sampling routine for Sand Creek was different from the other tributary sites. Two routine water-quality samples were collected in March and July, and two storm samples were collected between April 1 and September 30 .

Measurements of specific conductance, $\mathrm{pH}$, dissolved oxygen, Escherichia coli (E. coli), ammonia, nitrate plus nitrite, phosphorus, suspended sediment, and selected trace elements were made to characterize water quality in the Fountain and Monument Creek watersheds near Colorado Springs, Colorado. Samples for analysis of dissolved constituents were filtered using a 0.45 -micron filter and are hereafter referred to as dissolved; unfiltered samples are referred to as total samples. The trace elements analyzed include dissolved and total arsenic, dissolved boron, dissolved and total copper, total lead, dissolved and total manganese, total nickel, dissolved and total selenium, and dissolved and total zinc.

Suspended-sediment samples were collected from April 1 through September 30 in conjunction with routine and stormwater-quality samples to evaluate variations in suspended-sediment concentrations, discharge, and yield. In addition, suspended-sediment samples were collected daily by automatic samplers at Monument Creek above Woodmen (site 07103970, MoCr_Woodmen), Cottonwood Creek at mouth at Pikeview (site 07103990, lower_CoCr), Monument Creek at Bijou Street (site 07104905, MoCr_Bijou), Fountain Creek at Colorado Springs (site 07105500, FoCr_Nevada), Sand Creek above mouth (site 07105600, SaCr), and Fountain Creek at Security (site 07105800 , FoCr_Security) to evaluate daily variations in suspended-sediment concentrations, discharge, and yield. Automatic samplers were operated annually from April 1 through September 30. Routine and daily samples data were used to evaluate annual and spatial variations in suspended-sediment concentrations, discharge, and yield that occurred during cold-season flow, warm-season flow, and stormflow.

In addition to the above described sampling regime, during 2015, samples were collected quarterly and analyzed for E. coli at 41 sites (table 1) to aid in identifying and documenting dry weather discharges within stream segments listed as impaired for E. coli by the Colorado Department of Public Health and Environment (CDPHE) Water Quality Control 

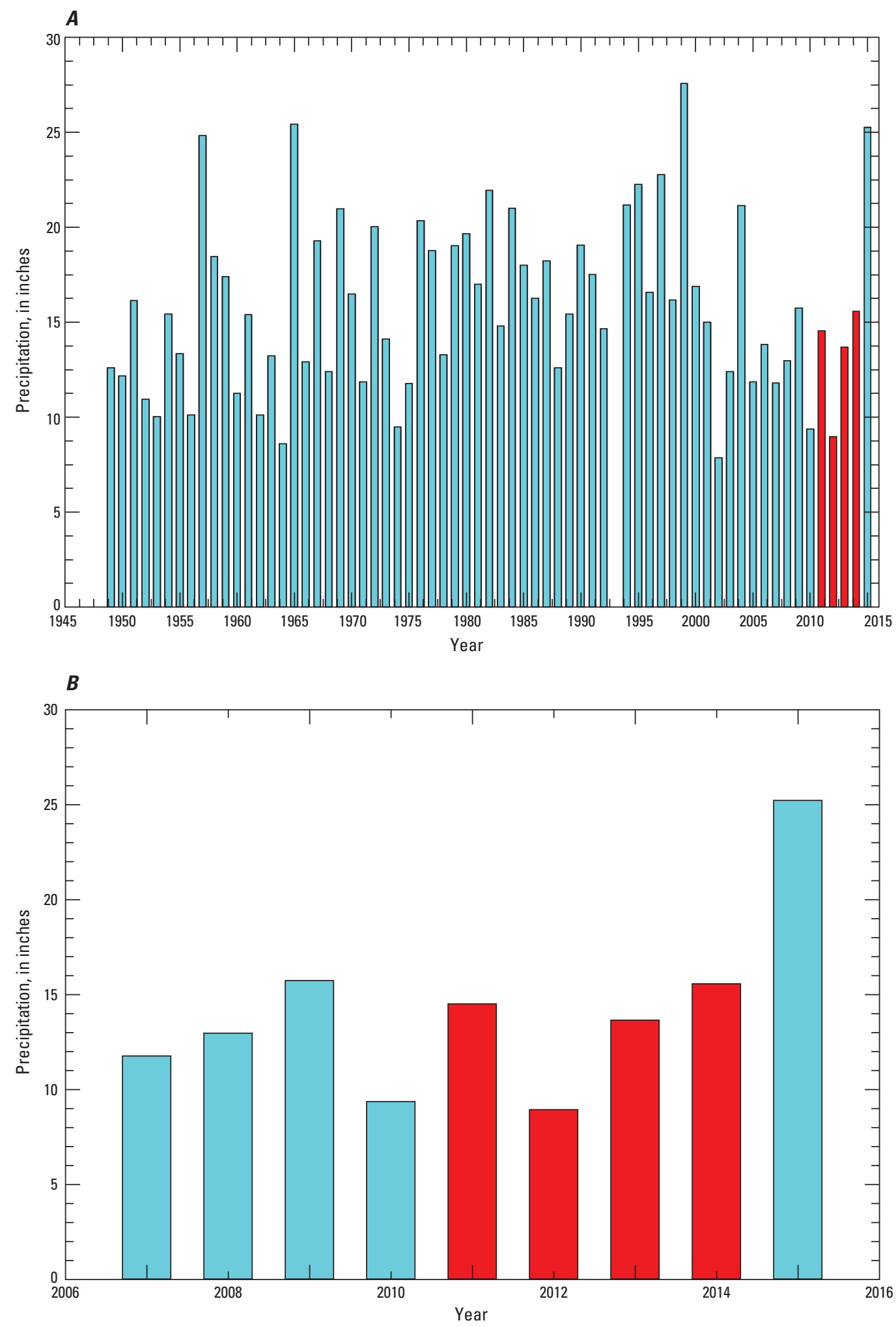

Figure 2. Annual precipitation at the Colorado Springs Weather Service Office Colorado; $A, 1949$ through 2015 and B, 2007 through 2015. (Data from Colorado Springs Weather Service Office, site identification number 51778, accessed 9/6/2016 at http://ccc.atmos.colostate.edu/dly form.html. Red colored bars indicate estimated data from U.S. Geological Survey precipitation monitoring site 385010104422901, accessed 4/26/2017 at https://waterdata.usgs.gov/nwis/inventory/?site_ no $=385010104422901 \&$ agency_cd=USGS\&amp.) 
Commission (Colorado Department of Public Health and Environment, 2016c). These dry weather samples were collected when streamflow discharge was greater than 5 gallons per minute (gal $/ \mathrm{min})$ at the sampling location, there had been at least 48 hours since the last precipitation event, and there was no evidence of snowmelt.

\section{Streamflow Regimes}

Water quality commonly varies with different streamflow regimes in the Fountain Creek watershed (Mau and others, 2007). Figure 3 shows an example of the seasonal (temporal) variations in streamflow that occur in the study area. Based on the observed seasonal variations in streamflow and results from previous studies, water-quality data were grouped into three streamflow regimes (cold-season flow, warm-season flow, and stormflow) for analysis (fig. 3). Cold-season flow was defined as the period November 1 through April 30, when streamflows were generally low and predominantly sustained by groundwater discharge, wastewater effluent, and other regulated discharges and not affected by stormflow. Warm-season flow was defined as the period May 1 through October 31, when streamflows were elevated above cold-season conditions because of snowmelt runoff. Stormflows were defined as daily mean streamflow larger than two times the computed daily cold-season flow for all main-stem sites. For the tributary sites, stormflow was defined as streamflow greater than three times the computed daily cold-season flow.

As in previous summaries of data collected for this study area (Edelmann and others, 2002; Mau and others, 2007), the number of stormflow events from May through October for each year were estimated from 2007 through 2015 by using a technique to separate the base-flow component from the daily mean streamflow (Wahl and Wahl, 1995). This computer program implements a deterministic procedure to estimate the base-flow component of the daily hydrograph by combining a local minimums approach with a recession slope test. Based on inspection of streamflow hydrographs, a decision was made that daily mean streamflow larger than two times the computed daily cold-season flow was a conservative indicator of stormflow for all main-stem sites. For the tributary sites, a daily mean streamflow larger than three times the computed daily cold-season flow was a conservative indicator of stormflow. Based on these techniques, between 2007 and 2015, the number of stormflow events per year generally ranged from 45 to 85 , with an average of 68 .

For sample sites located at U.S. Geological Survey (USGS) streamflow-gaging stations, instantaneous streamflow values were obtained from gage readings. At ungaged sites, instantaneous streamflow measurements were made when water-quality samples were collected (Rantz and others, 1982). Streamflow data used in this report are available from the USGS National Water Information System (NWIS) at http://dx.doi.org/10.5066/F7P55KJN (search by USGS site number given in table 1).

\section{Water-Quality Data}

Water-quality samples were collected and processed using standard USGS techniques and procedures (U.S. Geological Survey, 1977; Horowitz and others, 1994; Wilde and others, 1998). Sample processing was done primarily in a mobile USGS laboratory at the sampling site. Sampling equipment was cleaned using part-per-billion protocols (Wilde, 2004). Specific conductance, $\mathrm{pH}$, and dissolved oxygen measurements were made using protocols described by Wilde and others (1998). Water-quality constituents were analyzed at the USGS National Water Quality Laboratory (NWQL) in Denver, Colorado (Fishman and Friedman, 1989). Water-quality data used in this report are available from the USGS NWIS at http://dx.doi.org/10.5066/F7P55KJN (search by USGS site number given in table 1 ).

The "E" remark code is used to signify that a measured concentration or field value is estimated. For samples analyzed at the NWQL, analytes detected at concentrations less than the laboratory reporting level (LRL) and as low as the long term method detection level (LT-MDL) are reported with an "E" remark code, whereas non-detections are reported as less than LRL (Childress and others, 1999).

Instantaneous nutrient, trace element, and suspendedsediment loads were computed at selected sites in the study area by multiplying concentration data by streamflow and a unit conversion factor. In contrast to concentration data, instantaneous loads provide an estimate of the mass of a constituent transported past a given site at a given time and were expressed in pounds per day (lb/d). The instantaneous loads discussed in the report were based on a small dataset and may not represent the range in loads that occurred in the watershed during the study.

\section{Quality-Control Data}

Quality-control samples were routinely collected and analyzed to identify, quantify, and document bias and variability in the collection and processing of data (Wilde and others, 1998). Quality-control samples collected included field and equipment blanks and replicates. Field and equipment blanks were collected and analyzed to test for sample contamination. Replicate samples were collected to estimate variability in the environmental data. All quality-control samples were submitted to the NWQL for analysis.

Dissolved ammonia, dissolved nitrate plus nitrite, total phosphorus, total arsenic, dissolved and total copper, dissolved and total zinc, and dissolved selenium were detected in one or more field blanks (table 3). Concentrations of these constituents in the field blanks were low and usually less than or equal to the laboratory reporting levels. Concentrations measured in field blanks were small fractions of concentrations measured in the majority of environmental samples.

For each analyte, the relative percent difference was calculated as the absolute difference between a replicate and 


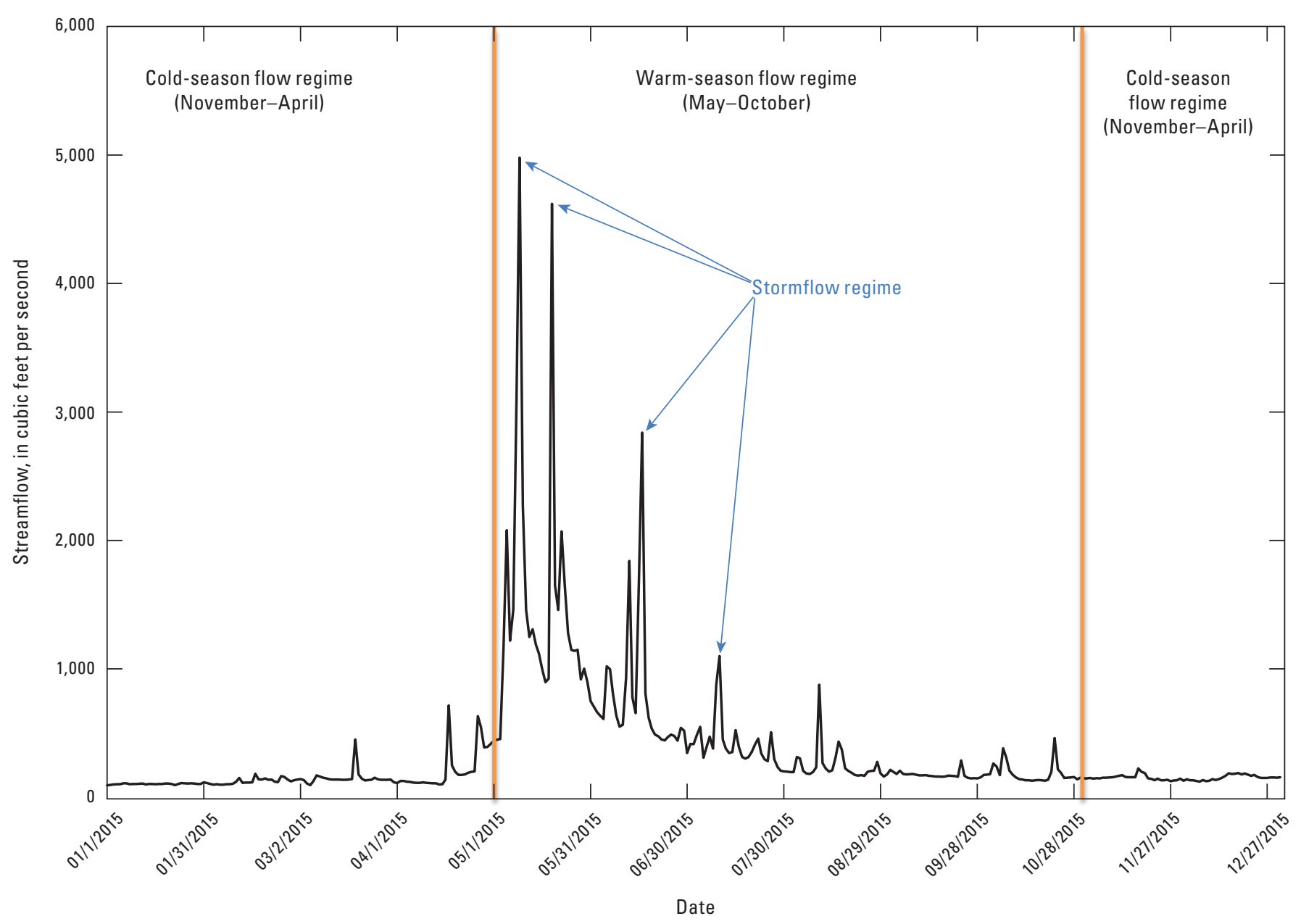

Figure 3. Annual hydrograph for site 07105800, Fountain Creek at Security, depicting flow regimes.

its paired environmental sample concentration, divided by the average of the two values, and multiplied by 100 . The mean relative percent difference among replicate samples ranged from about 2 percent for nutrient concentrations to about 3 percent for trace element concentrations. Consequently, the small relative percent differences (less than 5 percent) indicate that there was little variability introduced into the results by the collection, processing, and analysis of water-quality samples in this study.

\section{Suspended-Sediment Data}

Suspended-sediment samples generally were collected daily from April through September each year from 2007 through 2015 at six sites and at one site, 07105530 (FoCr_Janitell), from 2013 through 2015 (table 1). Discrete point samples were collected using automatic samplers installed at selected streamflow-gaging stations and were programmed to collect samples daily and during rises in stream stage. Suspended-sediment samples were also manually collected when routine water-quality samples were collected as described by Edwards and Glysson (1988). All suspended-sediment samples were analyzed at the USGS Iowa Water Science Center Sediment Laboratory, Iowa City, Iowa Guy (1969). Suspended-sediment concentrations obtained from samples collected by automatic samplers were adjusted on the basis of a relation developed from depthintegrated samples collected periodically using the equalwidth-increment method (Edwards and Glysson, 1988). The Graphical Constituent Loading Analysis System (GCLAS) program (Koltun and others, 2006) was used to analyze daily suspended-sediment concentration and streamflow to estimate the daily mean suspended-sediment concentration and discharge. Suspended-sediment data are available from the USGS NWIS at http://dx.doi.org/10.5066/F7P55KJN (search by USGS site number given in table 1).

Suspended-sediment discharge is the mass of suspended sediment transported over time and, in this report, is expressed in tons per day (tons/d). Sediment discharge in a stream is the result of erosion and sediment transport throughout the watershed. Some tributaries may discharge large volumes of sediment to a stream and others may discharge small 
Table 3. Field blank values, Fountain Creek watershed, Colorado, 2007-2015.

[USGS, U.S. Geological Survey, --, no value; N, nitrogen; P, phosphorus; mg/L, milligrams per liter; $\mu \mathrm{g} / \mathrm{L}$, micrograms per liter; E, estimated value; <, less than the value shown; gray shading, value detected]

\begin{tabular}{|c|c|c|c|c|c|c|c|c|c|c|c|c|c|c|c|c|c|}
\hline $\begin{array}{c}\text { USGS } \\
\text { site number }\end{array}$ & $\begin{array}{l}\text { Abbreviated } \\
\text { site name }\end{array}$ & $\begin{array}{l}\text { Date } \\
\text { (yyyv } \\
\text { mmdd) }\end{array}$ & $\begin{array}{c}\text { Time } \\
\text { (24-hour) }\end{array}$ & $\begin{array}{c}\text { Ammonia, } \\
\text { dissolved } \\
\text { (mg/L as N) }\end{array}$ & $\begin{array}{c}\text { Nitrate } \\
\text { plus } \\
\text { nitrite, } \\
\text { dissolved } \\
\text { (mg/L as N) }\end{array}$ & $\begin{array}{c}\text { Phos- } \\
\text { phorus, } \\
\text { total } \\
\text { (mg/L as P) }\end{array}$ & $\begin{array}{c}\text { Arsenic, } \\
\text { total } \\
(\mu \mathrm{g} / \mathrm{L})\end{array}$ & $\begin{array}{c}\text { Boron, } \\
\text { dissolved } \\
\text { ( } \mu \mathrm{g} / \mathrm{L})\end{array}$ & $\begin{array}{c}\text { Copper, } \\
\text { dissolved } \\
\text { ( } \mu \mathrm{g} / \mathrm{L})\end{array}$ & $\begin{array}{c}\text { Copper, } \\
\text { total } \\
(\mu \mathrm{g} / \mathrm{L})\end{array}$ & $\begin{array}{c}\text { Lead, } \\
\text { total } \\
(\mu \mathrm{g} / \mathrm{L})\end{array}$ & $\begin{array}{c}\text { Manga- } \\
\text { nese, } \\
\text { total } \\
(\mu \mathrm{g} / \mathrm{L})\end{array}$ & $\begin{array}{c}\text { Nickel, } \\
\text { total } \\
(\mu \mathrm{g} / \mathrm{L})\end{array}$ & $\begin{array}{c}\text { Zinc, } \\
\text { dissolved } \\
\text { ( } \mu \mathrm{g} / \mathrm{L})\end{array}$ & $\begin{array}{l}\text { Zinc, } \\
\text { total } \\
(\mu \mathrm{g} / \mathrm{L})\end{array}$ & $\begin{array}{c}\text { Selenium, } \\
\text { dissolved } \\
\text { ( } \mu \mathrm{g} / \mathrm{L})\end{array}$ & $\begin{array}{c}\text { Selenium, } \\
\text { total } \\
(\mu \mathrm{g} / \mathrm{L})\end{array}$ \\
\hline \multirow[t]{8}{*}{07103700} & FoCr_Manitou & 20100224 & 1044 & $<0.02$ & $<0.04$ & $<0.04$ & $<0.18$ & $<3$ & $<1.0$ & 1.9 & $<0.06$ & $<0.8$ & $<0.36$ & $<2.8$ & $<2.0$ & $<0.04$ & $<0.100$ \\
\hline & & 20110622 & 1214 & -- & -- & -- & -- & -- & -- & -- & -- & -- & -- & -- & -- & $<0.03$ & -- \\
\hline & & 20120424 & 1159 & -- & -- & -- & -- & -- & -- & -- & -- & -- & -- & -- & -- & $<0.03$ & -- \\
\hline & & 20121217 & 1159 & -- & -- & -- & -- & -- & -- & -- & -- & -- & -- & -- & -- & $<0.03$ & -- \\
\hline & & 20130128 & 1144 & -- & -- & $<0.004$ & -- & -- & -- & -- & -- & -- & -- & -- & -- & $<0.03$ & -- \\
\hline & & 20140710 & 1044 & $<0.01$ & $<0.040$ & $<0.004$ & $<0.28$ & $<5$ & $<0.80$ & $<0.80$ & $<0.04$ & $<0.4$ & $<0.20$ & $<2.0$ & $<2.0$ & $<0.05$ & $<0.100$ \\
\hline & & 20150205 & 1029 & $<0.01$ & $<0.040$ & $<0.004$ & $<0.20$ & $<5$ & $<0.80$ & $<0.80$ & $<0.04$ & $<0.4$ & $<0.20$ & $<2.0$ & $<2.0$ & $<0.05$ & $<0.100$ \\
\hline & & 20150811 & 1029 & -- & -- & -- & -- & -- & -- & -- & -- & -- & -- & -- & -- & $<0.05$ & -- \\
\hline \multirow[t]{5}{*}{07103707} & FoCr_8th & 20080514 & 1001 & $<0.02$ & $<0.04$ & $<0.008$ & $<0.60$ & $<6$ & $<1.0$ & $<1.2$ & $<0.06$ & $<0.40$ & $<0.12$ & $<1.8$ & $<2.0$ & $<0.04$ & $<0.080$ \\
\hline & & 20091008 & 1059 & $<0.02$ & $<0.04$ & $<0.04$ & -- & $<3$ & $<1.0$ & -- & -- & -- & -- & $<2.8$ & -- & $<0.04$ & -- \\
\hline & & 20120228 & 1414 & $<0.01$ & $<0.040$ & $<0.02$ & $<0.28$ & $<3$ & $<0.80$ & $<0.70$ & $<0.04$ & $<0.4$ & $<0.19$ & $<1.4$ & $<3.0$ & $<0.03$ & $<0.050$ \\
\hline & & 20131022 & 1344 & -- & -- & $<0.004$ & $<0.28$ & -- & $<0.80$ & $<0.80$ & -- & -- & $<0.20$ & $<2.0$ & -- & $<0.05$ & -- \\
\hline & & 20150902 & 1229 & -- & -- & $<0.004$ & -- & -- & -- & -- & -- & -- & -- & -- & -- & -- & -- \\
\hline 385854104470100 & upper_Ke & 20070620 & 1121 & $<0.02$ & 0.07 & 0.07 & -- & -- & -- & -- & -- & -- & -- & -- & -- & -- & -- \\
\hline 07103960 & lower_Ke & 20081006 & 1504 & $<0.02$ & $<0.04$ & $<0.04$ & -- & -- & -- & -- & -- & -- & -- & -- & -- & -- & -- \\
\hline \multirow[t]{3}{*}{07103970} & MoCr_Woodmen & 20080429 & 1044 & $<0.02$ & $<0.04$ & $<0.04$ & -- & $<6$ & $<1.0$ & -- & -- & -- & -- & $<1.8$ & -- & $<0.04$ & -- \\
\hline & & 20140203 & 1314 & $<0.01$ & $<0.040$ & $<0.004$ & $<0.28$ & $<5$ & $<0.80$ & $<0.80$ & $<0.04$ & $<0.4$ & $<0.20$ & $<2.0$ & $<2.0$ & $<0.05$ & $<0.100$ \\
\hline & & 20141003 & 1059 & $<0.01$ & $<0.040$ & $<0.004$ & $<0.20$ & $<5$ & $<0.80$ & $<0.80$ & $<0.04$ & $<0.4$ & $<0.20$ & $<2.0$ & $<2.0$ & $<0.05$ & $<0.100$ \\
\hline 07103990 & lower_CoCr & 20070619 & 1059 & E0.02 & $<0.06$ & $<0.04$ & -- & -- & -- & -- & -- & -- & -- & -- & -- & -- & -- \\
\hline 07104050 & N. RoCr & 20071009 & 1529 & $<0.02$ & $<0.04$ & $<0.04$ & -- & -- & -- & -- & -- & -- & -- & -- & -- & -- & -- \\
\hline \multirow[t]{7}{*}{07104905} & MoCr_Bijou & 20100727 & 1244 & $<0.02$ & $<0.04$ & $<0.04$ & E0.09 & $<3$ & $<1.0$ & $<1.4$ & $<0.06$ & $<0.8$ & $<0.36$ & $<2.8$ & $<2.0$ & $<0.04$ & $<0.100$ \\
\hline & & 20110725 & 1359 & 0.01 & $<0.02$ & $<0.02$ & $<0.09$ & $<3$ & $<0.50$ & $<0.70$ & $<0.04$ & $<0.4$ & $<0.12$ & $<1.4$ & $<2.4$ & $<0.03$ & $<0.050$ \\
\hline & & 20120628 & 1259 & -- & -- & -- & -- & -- & -- & -- & -- & -- & -- & -- & -- & $<0.03$ & -- \\
\hline & & 20130506 & 1244 & -- & -- & $<0.004$ & $<0.28$ & -- & $<0.80$ & $<0.70$ & -- & $<0.4$ & $<0.19$ & $<1.4$ & $<3.0$ & $<0.03$ & $<0.050$ \\
\hline & & 20140304 & 1044 & -- & -- & $<0.004$ & -- & -- & -- & -- & -- & -- & -- & -- & -- & $<0.05$ & -- \\
\hline & & 20141104 & 1229 & -- & -- & $<0.004$ & -- & -- & -- & -- & -- & -- & -- & -- & -- & $<0.05$ & -- \\
\hline & & 20151104 & 1114 & -- & -- & $<0.004$ & -- & -- & -- & -- & -- & -- & -- & -- & -- & $<0.05$ & -- \\
\hline \multirow[t]{7}{*}{07105500} & FoCr_Nevada & 20070214 & 1459 & E0.010 & $<0.06$ & $<0.04$ & -- & $<8$ & $<0.40$ & -- & -- & -- & -- & 0.90 & -- & $<0.08$ & -- \\
\hline & & 20070718 & 1229 & $<0.02$ & $<0.06$ & E0.02 & -- & $<8$ & $<0.40$ & -- & -- & -- & -- & E0.56 & -- & $<0.08$ & -- \\
\hline & & 20090223 & 1014 & E0.01 & $<0.04$ & $<0.04$ & $<0.20$ & $<4$ & $<1.0$ & $<4.0$ & $<0.10$ & $<0.4$ & $<0.20$ & $<2.0$ & $<2.0$ & $<0.06$ & $<0.120$ \\
\hline & & 20110929 & 1344 & -- & -- & -- & -- & -- & -- & -- & -- & -- & -- & -- & -- & $<0.03$ & -- \\
\hline & & 20120830 & 1114 & -- & -- & -- & -- & -- & -- & -- & -- & -- & -- & -- & -- & $<0.03$ & -- \\
\hline & & 20130320 & 1014 & -- & -- & $<0.004$ & -- & -- & -- & -- & -- & -- & -- & -- & -- & $<0.03$ & -- \\
\hline & & 20140904 & 1314 & -- & -- & $<0.004$ & -- & -- & -- & -- & -- & -- & -- & -- & -- & $<0.05$ & -- \\
\hline \multirow[t]{8}{*}{07105530} & FoCr_Janitell & 20090514 & 1059 & E0.02 & $<0.04$ & $<0.04$ & $<0.20$ & $<4$ & $<1.0$ & $<4.0$ & $<0.10$ & $<0.4$ & $<0.20$ & $<2.0$ & 5.5 & $<0.06$ & $<0.120$ \\
\hline & & 20110526 & 1329 & 0.01 & $<0.02$ & $<0.02$ & $<0.09$ & $<3$ & $<0.50$ & $<0.70$ & $<0.04$ & $<0.4$ & $<0.12$ & $<1.4$ & $<2.4$ & $<0.03$ & $<0.050$ \\
\hline & & 20120124 & 0959 & -- & -- & -- & -- & -- & -- & -- & -- & -- & -- & -- & -- & $<0.03$ & -- \\
\hline & & 20121127 & 1314 & -- & -- & -- & -- & -- & -- & -- & -- & -- & -- & -- & -- & $<0.03$ & -- \\
\hline & & 20130606 & 1059 & -- & -- & $<0.004$ & -- & -- & -- & -- & -- & -- & -- & -- & -- & $<0.03$ & -- \\
\hline & & 20140513 & 1129 & $<0.01$ & $<0.040$ & $<0.004$ & $<0.28$ & $<5$ & $<0.80$ & $<0.80$ & $<0.04$ & $<0.4$ & $<0.20$ & $<2.0$ & $<2.0$ & $<0.05$ & $<0.100$ \\
\hline & & 20150107 & 1459 & -- & -- & $<0.004$ & -- & -- & -- & -- & -- & -- & -- & -- & -- & $<0.05$ & -- \\
\hline & & 20150707 & 1314 & $<0.01$ & $<0.040$ & $<0.004$ & $<0.20$ & $<5$ & $<0.80$ & $<0.80$ & $<0.04$ & $<0.4$ & $<0.20$ & $<2.0$ & $<2.0$ & $<0.05$ & $<0.100$ \\
\hline
\end{tabular}


Table 3. Field blank values, Fountain Creek watershed, Colorado, 2007-2015.-Continued

[USGS, U.S. Geological Survey, --, no value; N, nitrogen; P, phosphorus; mg/L, milligrams per liter; $\mu \mathrm{g} / \mathrm{L}$, micrograms per liter; E, estimated value; <, less than the value shown; gray shading, value detected]

\begin{tabular}{|c|c|c|c|c|c|c|c|c|c|c|c|c|c|c|c|c|c|}
\hline $\begin{array}{c}\text { USGS } \\
\text { site number }\end{array}$ & $\begin{array}{c}\text { Abbreviated } \\
\text { site name }\end{array}$ & $\begin{array}{l}\text { Date } \\
\text { (yyyy } \\
\text { mmdd) }\end{array}$ & $\begin{array}{c}\text { Time } \\
\text { (24-hour) }\end{array}$ & $\begin{array}{c}\text { Ammonia, } \\
\text { dissolved } \\
\text { (mg/L as N) }\end{array}$ & $\begin{array}{c}\text { Nitrate } \\
\text { plus } \\
\text { nitrite, } \\
\text { dissolved } \\
\text { (mg/L as N) }\end{array}$ & $\begin{array}{c}\text { Phos- } \\
\text { phorus, } \\
\text { total } \\
\text { (mg/L as } \mathrm{P} \text { ) }\end{array}$ & $\begin{array}{c}\text { Arsenic, } \\
\text { total } \\
(\mu \mathrm{g} / \mathrm{L})\end{array}$ & $\begin{array}{c}\text { Boron, } \\
\text { dissolved } \\
\text { ( } \mu \mathrm{g} / \mathrm{L})\end{array}$ & $\begin{array}{c}\text { Copper, } \\
\text { dissolved } \\
(\mu \mathrm{g} / \mathrm{L})\end{array}$ & $\begin{array}{c}\text { Copper, } \\
\text { total } \\
(\mu \mathrm{g} / \mathrm{L})\end{array}$ & $\begin{array}{c}\text { Lead, } \\
\text { total } \\
(\mu \mathrm{g} / \mathrm{L})\end{array}$ & $\begin{array}{c}\text { Manga- } \\
\text { nese, } \\
\text { total } \\
(\mu \mathrm{g} / \mathrm{L})\end{array}$ & $\begin{array}{c}\text { Nickel, } \\
\text { total } \\
\text { ( } \mu \mathrm{g} / \mathrm{L})\end{array}$ & $\begin{array}{c}\text { Zinc, } \\
\text { dissolved } \\
\text { ( } \mu \mathrm{g} / \mathrm{L})\end{array}$ & $\begin{array}{l}\text { Zinc, } \\
\text { total } \\
(\mu \mathrm{g} / \mathrm{L})\end{array}$ & $\begin{array}{c}\text { Selenium, } \\
\text { dissolved } \\
\text { ( } \mu \mathrm{g} / \mathrm{L})\end{array}$ & $\begin{array}{c}\text { Selenium, } \\
\text { total } \\
(\mu \mathrm{g} / \mathrm{L})\end{array}$ \\
\hline \multirow[t]{7}{*}{07105800} & \multirow[t]{7}{*}{ FoCr_Security } & 20070529 & 1359 & $<0.02$ & $<0.06$ & $<0.04$ & -- & $<8$ & E0.35 & -- & -- & -- & -- & 0.50 & -- & $<0.08$ & -- \\
\hline & & 20100624 & 1114 & E0.01 & $<0.04$ & $<0.04$ & E0.13 & $<3$ & $<1.0$ & $<1.4$ & $<0.06$ & $<0.8$ & $<0.36$ & $<2.8$ & $<2.0$ & E0.02 & $<0.100$ \\
\hline & & 20110427 & 0959 & -- & -- & -- & -- & -- & -- & -- & -- & -- & -- & -- & -- & $<0.03$ & -- \\
\hline & & 20120726 & 1414 & $<0.01$ & $<0.040$ & $<0.02$ & $<0.28$ & $<3$ & $<0.80$ & 1.7 & $<0.04$ & $<0.4$ & $<0.19$ & $<1.4$ & $<3.0$ & $<0.03$ & $<0.050$ \\
\hline & & 20130227 & 0959 & -- & -- & $<0.004$ & $<0.28$ & -- & $<0.80$ & $<0.70$ & -- & -- & $<0.19$ & $<1.4$ & -- & $<0.03$ & $<0.050$ \\
\hline & & 20130709 & 1444 & $<0.01$ & $<0.040$ & $<0.004$ & $<0.28$ & $<3$ & $<0.80$ & $<0.70$ & $<0.04$ & $<0.4$ & $<0.19$ & $<1.4$ & $<3.0$ & $<0.03$ & $<0.050$ \\
\hline & & 20150303 & 1144 & -- & -- & $<0.004$ & -- & -- & -- & -- & -- & -- & -- & -- & -- & $<0.05$ & -- \\
\hline
\end{tabular}


volumes. Additionally, in-channel processes erode banks, mobilize (scour) bed sediments, and deposit (fill) bed sediments. Eroded sediments can be transported by two modes: rolling, bouncing, and sliding along the bed as "bedload," or transported in the water column by turbulence as "suspended load" (Edwards and Glysson, 1988). Total sediment load is the sum of bedload and suspended load. von Guerard (1989b) indicated that in Monument and Fountain Creek, bedload represented about 6 to 30 percent of the total sediment load during stormflow. Daily suspended-sediment yield was computed by dividing the daily suspended-sediment discharge by the drainage area and does not account for bedload, and in this report, is expressed in tons per day per square mile (ton $/ \mathrm{d} / \mathrm{mi}^{2}$ ). von Guerard (1989a) indicated that the areas producing the largest suspended-sediment yields tended to be in streams on the readily erodible Colorado Piedmont.

\section{Statistical Analyses}

Water-quality and suspended-sediment data presented in this report were summarized using boxplots. Boxplots graphically display the constituent variability and provide an easy visual method for comparing spatial, temporal, and flow-related data. Boxplots are useful because the variability between datasets, extreme values, and selected summary statistics are easily observed. Boxplots contain the following information: The horizontal line within the box represents the median value ( 50 percent of the data are larger than this value and 50 percent of the data are less than this value). The lower horizontal line of the box is the 25th percentile or lower quartile ( 25 percent of the data are less than this value). The upper horizontal line of the box is the 75th percentile or upper quartile ( 75 percent of the data are less than this value). The interquartile range (IQR) contains the values between the 25 th and 75 th percentiles and is the difference between the 25th and 75th percentiles. The bottom of the vertical line on the boxplot is the smallest value within 1.5 times the IQR of the box. The top of the vertical line on the boxplot is the largest value within 1.5 times the IQR of the box. Outlier values are larger than 1.5 times the IQR from the box.

Concentrations of some constituents in some samples were qualified with a less than, estimated, or greater than remark code next to the reported value. These values were used to generate boxplots and summary tables, and the remark code was shown with the value. For example, minimum values of dissolved ammonia were frequently reported as less than the laboratory reporting level of 0.01 or 0.02 ; the less than code was shown with the minimum value in the table. Minimum, maximum, and median values were computed for water-quality constituents using R (R Core Team, 2016). These summary statistics were used to compare differences in water-quality constituent concentrations between flow regimes at a given site and to evaluate spatial differences in waterquality constituent concentrations throughout the study area.

The nonparametric Mann-Whitney test (Helsel and Hirsch, 1992) was used to determine whether there were spatial and temporal differences for suspended-sediment concentrations, discharge, and suspended-sediment yields. The Mann-Whitney test is a nonparametric test used to compare two populations (datasets). Specifically, it is used to test the null hypothesis that two datasets have identical distribution functions against the alternative hypothesis that the two distribution functions differ only with respect to location (median), if at all. For the purpose of this study, the null hypothesis is the statistical hypothesis that there is no difference in constituent concentrations between datasets. The $p$-value is the probability of wrongly rejecting the null hypothesis if it is in fact true. The confidence interval is a measure of the degree of certainty with which the decision to reject the null hypothesis is made. For the current study, a confidence interval of 0.95 or 95 percent was used. The null hypothesis, that the populations are different, was rejected when the $p$-value was 0.05 or less.

\section{Water Quality and Suspended Sediment in the Fountain and Monument Creek Watersheds}

The following sections of the report characterize water quality and sediment in the Fountain and Monument Creek watersheds using data collected from 2007 through 2015. To characterize water quality and sediment conditions: (1) values of onsite measurements of specific conductance, $\mathrm{pH}$, and dissolved oxygen and concentrations of $E$. coli, dissolved nitrate plus nitrite, total phosphorus, ammonia, selected trace elements, and suspended sediment were compared spatially and in relation to streamflow conditions, (2) concentrations of selected constituents were compared to Colorado in-stream water-quality standards, and (3) water-quality loads were estimated and compared for selected constituents during warmseason flow and stormflow conditions.

Specific conductance, $\mathrm{pH}$, and dissolved oxygen were measured onsite when water-quality samples were collected. Additional measurements of specific conductance, $\mathrm{pH}$, and dissolved oxygen done as part of routine sampling for other projects from 2007 through 2015 were also included in this analysis.

Samples were collected and analyzed for dissolved ammonia, nitrate plus nitrite as nitrogen, (referred to as nitrate plus nitrite in this report), and total phosphorus at multiple main-stem and tributary sites. The standard for nitrate plus nitrite that was compared to sample concentrations in this report is 10 milligrams per liter $(\mathrm{mg} / \mathrm{L})$ (Colorado Department of Public Health and Environment, 2016a).

Samples were collected and analyzed for E. coli bacteria at multiple main-stem and tributary sites throughout the study area. These bacteria are "indicator bacteria," which are used to identify a potential for pathogenicity in water samples (U.S. Environmental Protection Agency, 2004). All stream segments in the Fountain Creek Watershed are classified as 
"Recreation E" use. The standard for E. coli bacteria that was referenced in this report was based on the recreational use standard of 126 colonies per 100 milliliters for streams classified as "Recreation E" (col/100 mL) (Colorado Department of Public Health and Environment, 2016a).

Trace elements are inorganic chemicals that usually occur in small amounts in nature. Samples collected at mainstem sites were analyzed for the following trace elements: dissolved and total arsenic, dissolved boron, dissolved and total copper, total lead, dissolved and total manganese, total nickel, dissolved and total selenium, and dissolved and total zinc. Samples collected at tributary site Sand Creek above mouth $(07105600, \mathrm{SaCr})$ were analyzed for total arsenic, total copper, total lead, total manganese, total nickel, dissolved and total selenium, and total zinc. Total and dissolved selenium samples were collected at four additional tributary sites including Kettle Creek (07103960), Cottonwood Creek (07103990, lower_CoCr), Mesa Creek (385124104501301, lower_MeCr), and Bear Creek (384909104504401, lower_BeCr).

In-stream water-quality standards have been established for stream segments in the Fountain and Monument Creek watersheds. Standards are based on stream classifications and designated use of the stream segment as determined by the Colorado Department of Public Health and Environment (CDPHE) Water Quality Control Commission with public participation (Colorado Department of Public Health and Environment, 2016a). Standards for many constituents are fixed values; standards for other constituents, specifically for some trace elements, are calculated values that use mean hardness in determining the standard for each site. The mean hardness used in this report was calculated at each mainstem site using the lower 95-percentile confidence interval for cold-season water-quality samples collected between November and March (Colorado Department of Public Health and Environment, 2016b). The acute standards for dissolved copper and dissolved zinc varied by site and were based on mean cold-season hardness. The acute standard for dissolved copper ranged from 9.68 to 25.6 micrograms per liter (mg/L), and the acute standard for dissolved zinc ranged from 116 to $296 \mathrm{mg} / \mathrm{L}$. The Colorado Department of Public Health and Environment (2016a) defined an acute standard as the level not to be exceeded by a concentration in a single sample or by an average calculated from all samples collected during a 1-day period. The acute standard used in this report for total arsenic was $50 \mathrm{mg} / \mathrm{L}$ and for dissolved selenium was $18.4 \mathrm{mg} / \mathrm{L}$. In-stream water-quality standards for nitrate plus nitrite, E. coli, and selected trace elements were compared to concentrations of these constituents in stream samples to characterize water quality in the study area.

\section{Upper Fountain Creek Watershed}

Water-quality samples were collected during coldseason flows and warm-season flows at sites 07103700 (FoCr_Manitou) and 07103707 (FoCr_8th) along Upper Fountain Creek. Stormflow samples were only collected at site 07103700 (FoCr Manitou). As a result, changes in water-quality constituent concentrations along Upper Fountain Creek could not be evaluated during stormflows. Between 2007 and 2015, the median cold-season flow, based on streamflow measurements when samples were collected, decreased from 10.0 cubic feet per second $\left(\mathrm{ft}^{3} / \mathrm{s}\right)$ at 07103700 (FoCr_Manitou) to $9.1 \mathrm{ft}^{3} / \mathrm{s}$ at 07103707 (FoCr_8th), and the median warm-season flow increased from $9.9 \mathrm{ft}^{3} / \mathrm{s}$ to $14.0 \mathrm{ft}^{3} / \mathrm{s}$, respectively (table 4). In 2015, additional samples for $E$. coli bacteria were collected quarterly during dry weather conditions (described in the Methods of Investigation section of this report) at site 385116104523301 on Fountain Creek and site 385108104522001 on Camp Creek.

Runoff from a recent wildfire and a historic gold mill tailings pile are potential sources for elevated nutrients and trace elements in surface water in Upper Fountain Creek. From June 23, 2012, to July 10, 2012, the Waldo Canyon fire burned 18,247 acres within and near the Upper Fountain Creek watershed (City of Colorado Springs, 2013). Post-fire runoff may contain high levels of nutrients, from burned vegetation and fire retardants, and high levels of suspended sediment because reduced infiltration into fire-affected soils increases overland flow (Moody and Martin, 2001; Smith and others, 2011; State of New Mexico Environment Department, 2017). Gold Hill Mesa is a tailings pile for a former gold refinery located just upstream from the confluence with Monument Creek and upstream from site 07103707 (FoCr_8th). In 2004, the Gold Hill Mesa area received authorization to build 1,400 houses and 700,000 square feet of office and retail space on the tailings (Philips, 2017). Ground broke on the project in March 2005 and building is presently (2017) ongoing. Development on the tailings pile has the potential to increase suspended-sediment concentrations in runoff, and thus, increase trace element loads to the stream, particularly during stormflows. The following sections of the report discuss waterquality constituent values and loads in the Upper Fountain Creek watershed.

\section{Specific Conductance, $\mathrm{pH}$, and Dissolved Oxygen}

Between sites 07103700 (FoCr_Manitou) and 07103707 (FoCr_8th), specific-conductance values increased, whereas, dissolved oxygen and $\mathrm{pH}$ values remained relatively constant. Values of specific conductance measured in the Upper Fountain Creek watershed ranged from 112 to $2,410 \mu \mathrm{S} / \mathrm{cm}$ (table 4). Specific-conductance values generally decreased as streamflow increased at both sites (figs. 4 and 5). The median cold-season flow specific-conductance value increased in the downstream direction from $356 \mu \mathrm{S} / \mathrm{cm}$ at site 07103700 (FoCr_Manitou) to $522 \mu \mathrm{S} / \mathrm{cm}$ at site 07103707 (FoCr_8th). Dissolved oxygen concentrations ranged from 6.10 to $11.9 \mathrm{mg} / \mathrm{L}$. Median dissolved oxygen concentrations were higher during cold-season flows than during warm-season flows at both sites (table 4). Median $\mathrm{pH}$ values ranged from 8.1 to 8.3 (table 4 ). 
Table 4. Minimum, median, and maximum values for selected field parameters and discharge at sites in the Fountain Creek watershed, Colorado, 2007 through 2015.

[USGS, U.S. Geological Survey; Main, main-stem site; Trib, tributary site; $\mu \mathrm{S} / \mathrm{cm}$, microsiemens per centimeter; mg/L, milligrams per liter; N, number of samples; $\mathrm{CaCO}_{3}$, calcium carbonate; --, no value]

\begin{tabular}{|c|c|c|c|c|c|c|c|c|c|c|c|c|c|}
\hline \multirow{2}{*}{$\begin{array}{c}\text { USGS } \\
\text { site number }\end{array}$} & \multirow{2}{*}{$\begin{array}{l}\text { Site } \\
\text { type }\end{array}$} & \multicolumn{4}{|c|}{ Cold-season flow } & \multicolumn{4}{|c|}{ Warm-season flow } & \multicolumn{4}{|c|}{ Stormflow } \\
\hline & & $\mathbf{N}$ & Minimum & Median & Maximum & $\mathbf{N}$ & Minimum & Median & Maximum & $\mathbf{N}$ & Minimum & Median & Maximum \\
\hline \multicolumn{14}{|c|}{ Specific conductance $(\mu \mathrm{s} / \mathrm{cm})$} \\
\hline 07103700 & Main & 101 & 180 & 356 & 735 & 97 & 164 & 349 & 769 & 37 & 112 & 245 & 525 \\
\hline 07103707 & Main & 33 & 374 & 522 & 1,110 & 64 & 155 & 428 & 2,410 & -- & -- & -- & -- \\
\hline 385854104470100 & Trib & -- & -- & -- & -- & 5 & 335 & 393 & 434 & 1 & 236 & 236 & 236 \\
\hline 07103960 & Trib & 2 & 589 & 637 & 684 & 18 & 125 & 475.5 & 625 & 1 & 215 & 215 & 215 \\
\hline 385750104475001 & Trib & -- & -- & -- & -- & 6 & 161 & 540 & 583 & -- & -- & -- & -- \\
\hline 07103970 & Main & 79 & 226 & 529 & 1,960 & 76 & 209 & 484 & 845 & 26 & 96 & 185 & 447 \\
\hline 07103977 & Trib & -- & -- & -- & -- & 4 & 447 & 468 & 498 & 2 & 270 & 325 & 380 \\
\hline 07103985 & Trib & -- & -- & -- & -- & 6 & 437 & 942 & 1,000 & -- & -- & -- & -- \\
\hline 07103990 & Trib & 10 & 737 & 817 & 2,470 & 43 & 589 & 736 & 1,250 & 10 & 141 & 329 & 747 \\
\hline 07104050 & Trib & -- & -- & -- & -- & 4 & 1,750 & 2,065 & 2,210 & 2 & 248 & 409 & 570 \\
\hline 385501104483701 & Trib & -- & -- & -- & -- & 2 & 758 & 777 & 796 & -- & -- & -- & -- \\
\hline 385204104510101 & Trib & -- & -- & -- & -- & 4 & 533 & 575 & 685 & 1 & 330 & 330 & 330 \\
\hline 385124104501301 & Trib & 3 & 895 & 1,030 & 1,130 & 18 & 342 & 770 & 1,470 & 3 & 520 & 551 & 663 \\
\hline 07104905 & Main & 70 & 350 & 711 & 1,300 & 74 & 316 & 623 & 820 & 52 & 135 & 365 & 785 \\
\hline 07105000 & Trib & -- & -- & -- & -- & 6 & 75 & 83 & 101 & -- & -- & -- & -- \\
\hline 384909104504401 & Trib & 2 & 435 & 634 & 832 & 19 & 124 & 399 & 884 & -- & -- & -- & -- \\
\hline 07105500 & Main & 132 & 278 & 698 & 1,260 & 171 & 230 & 613 & 1,210 & 47 & 151 & 378 & 700 \\
\hline 07105530 & Main & 46 & 590 & 735 & 1,060 & 49 & 347 & 667 & 804 & 23 & 130 & 278 & 651 \\
\hline 07105600 & Trib & 13 & 781 & 1,270 & 1,530 & 40 & 646 & 1,115 & 1,280 & 34 & 122 & 459 & 966 \\
\hline 07105800 & Main & 126 & 325 & 800 & 1,280 & 117 & 365 & 752 & 1,270 & 28 & 200 & 430 & 665 \\
\hline \multicolumn{14}{|c|}{$\mathrm{pH}$ (standard units) } \\
\hline 07103700 & Main & 36 & 7.8 & 8.3 & 8.5 & 38 & 7.6 & 8.3 & 8.7 & 24 & 7.4 & 8.1 & 8.4 \\
\hline 07103707 & Main & 33 & 7.7 & 8.2 & 8.5 & 62 & 7.6 & 8.1 & 8.8 & -- & -- & -- & -- \\
\hline 385854104470100 & Trib & -- & -- & -- & -- & 5 & 7.9 & 8.1 & 8.8 & 1 & 7.5 & 7.5 & 7.5 \\
\hline 07103960 & Trib & 2 & 7.5 & 7.9 & 8.3 & 18 & 7.7 & 8 & 8.2 & 1 & 7.8 & 7.8 & 7.8 \\
\hline 385750104475001 & Trib & -- & -- & -- & -- & 6 & 7.6 & 8.2 & 8.4 & -- & -- & -- & -- \\
\hline 07103970 & Main & 12 & 8.0 & 8.2 & 8.5 & 23 & 8.1 & 8.3 & 8.9 & 20 & 7.5 & 8.0 & 8.4 \\
\hline 07103977 & Trib & -- & -- & -- & -- & 4 & 7.6 & 8.1 & 8.2 & 2 & 7.3 & 7.7 & 8.1 \\
\hline 07103985 & Trib & -- & -- & -- & -- & 6 & 7.8 & 8.3 & 8.6 & -- & -- & -- & -- \\
\hline 07103990 & Trib & 10 & 8.2 & 8.4 & 8.5 & 42 & 7.8 & 8.4 & 8.8 & 9 & 7.6 & 8.2 & 8.5 \\
\hline 07104050 & Trib & -- & -- & -- & -- & 4 & 8.1 & 8.2 & 8.5 & 2 & 7.8 & 7.9 & 8.0 \\
\hline 385501104483701 & Trib & -- & -- & -- & -- & 2 & 8.3 & 8.4 & 8.4 & -- & -- & -- & -- \\
\hline 385204104510101 & Trib & -- & -- & -- & -- & 4 & 8.3 & 8.4 & 8.4 & 1 & 8.0 & 8.0 & 8.0 \\
\hline 385124104501301 & Trib & 3 & 8.2 & 8.2 & 8.2 & 18 & 8.0 & 8.3 & 8.5 & 3 & 8.2 & 8.3 & 8.3 \\
\hline 07104905 & Main & 34 & 8.2 & 8.5 & 9.0 & 39 & 8.1 & 8.4 & 9.0 & 17 & 7.7 & 8.1 & 8.4 \\
\hline 07105000 & Trib & -- & -- & -- & -- & 6 & 7.4 & 7.7 & 8.0 & -- & -- & -- & -- \\
\hline 384909104504401 & Trib & 2 & 8.1 & 8.2 & 8.3 & 19 & 7.8 & 8.0 & 8.8 & -- & -- & -- & -- \\
\hline 07105500 & Main & 38 & 8.0 & 8.4 & 9.0 & 44 & 7.7 & 8.2 & 8.8 & 19 & 7.5 & 8.1 & 8.5 \\
\hline 07105530 & Main & 34 & 7.8 & 8.1 & 8.5 & 37 & 7.8 & 8.1 & 8.4 & 23 & 6.7 & 7.9 & 8.7 \\
\hline 07105600 & Trib & 2 & 8.2 & 8.3 & 8.3 & 13 & 8.0 & 8.2 & 8.4 & 7 & 7.7 & 7.8 & 8.7 \\
\hline 07105800 & Main & 35 & 8.1 & 8.4 & 8.8 & 42 & 8.0 & 8.4 & 8.8 & 13 & 7.6 & 7.9 & 8.1 \\
\hline
\end{tabular}




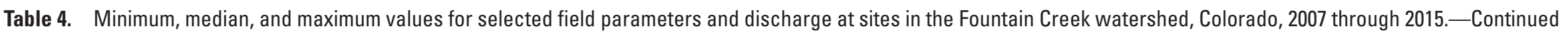
[USGS, U.S. Geological Survey; Main, main-stem site; Trib, tributary site; $\mu \mathrm{S} / \mathrm{cm}$, microsiemens per centimeter; mg/L, milligrams per liter; N, number of samples; CaCO${ }_{3}$, calcium carbonate; --, no value]

\begin{tabular}{|c|c|c|c|c|c|c|c|c|c|c|c|c|c|}
\hline \multirow{2}{*}{$\begin{array}{c}\text { USGS } \\
\text { site number }\end{array}$} & \multirow{2}{*}{$\begin{array}{l}\text { Site } \\
\text { type }\end{array}$} & \multicolumn{4}{|c|}{ Cold-season flow } & \multicolumn{4}{|c|}{ Warm-season flow } & \multicolumn{4}{|c|}{ Stormflow } \\
\hline & & $\mathbf{N}$ & Minimum & Median & Maximum & $\mathbf{N}$ & Minimum & Median & Maximum & $\mathbf{N}$ & Minimum & Median & Maximum \\
\hline \multicolumn{14}{|c|}{ Dissolved oxygen (mg/L) } \\
\hline 07103700 & Main & 36 & 8.20 & 10.6 & 11.9 & 35 & 7.30 & 8.60 & 11.1 & 23 & 7.10 & 8.40 & 10.2 \\
\hline 07103707 & Main & 25 & 7.80 & 10.3 & 11.8 & 45 & 6.10 & 8.00 & 10.0 & -- & -- & -- & -- \\
\hline 385854104470100 & Trib & -- & -- & -- & -- & 5 & 7.00 & 8.20 & 9.30 & -- & -- & -- & -- \\
\hline 07103960 & Trib & 2 & 10.6 & 10.9 & 11.1 & 17 & 6.10 & 7.90 & 10.1 & -- & -- & -- & -- \\
\hline 385750104475001 & Trib & -- & -- & -- & -- & 5 & 6.90 & 8.10 & 9.80 & -- & -- & -- & -- \\
\hline 07103970 & Main & 12 & 8.20 & 10.5 & 11.6 & 23 & 6.40 & 8.30 & 9.80 & 20 & 6.90 & 8.40 & 9.60 \\
\hline 07103977 & Trib & -- & -- & -- & -- & 4 & 5.80 & 7.60 & 8.10 & 1 & 8.60 & 8.60 & 8.60 \\
\hline 07103985 & Trib & -- & -- & -- & -- & 6 & 6.50 & 9.00 & 11.1 & -- & -- & -- & -- \\
\hline 07103990 & Trib & 10 & 7.50 & 8.80 & 11.9 & 39 & 6.20 & 7.70 & 9.90 & 9 & 7.00 & 7.90 & 8.60 \\
\hline 07104050 & Trib & -- & -- & -- & -- & 4 & 6.30 & 7.60 & 8.60 & 2 & 8.10 & 8.30 & 8.40 \\
\hline 385501104483701 & Trib & -- & -- & -- & -- & 2 & 7.40 & 8.00 & 8.60 & -- & -- & -- & -- \\
\hline 385204104510101 & Trib & -- & -- & -- & -- & 4 & 7.20 & 8.00 & 8.10 & 1 & 8.30 & 8.30 & 8.30 \\
\hline 385124104501301 & Trib & 3 & 10.3 & 11.2 & 11.3 & 18 & 6.50 & 8.00 & 9.60 & 3 & 6.90 & 7.50 & 8.20 \\
\hline 07104905 & Main & 34 & 8.40 & 10.3 & 11.5 & 39 & 6.30 & 8.10 & 10.0 & 16 & 6.30 & 7.70 & 9.60 \\
\hline 07105000 & Trib & -- & -- & -- & -- & 6 & 8.20 & 8.70 & 10.3 & -- & -- & -- & -- \\
\hline 384909104504401 & Trib & 2 & 10.2 & 10.8 & 11.3 & 18 & 7.30 & 8.30 & 9.80 & -- & -- & -- & -- \\
\hline 07105500 & Main & 36 & 7.60 & 10.1 & 11.8 & 37 & 6.40 & 7.80 & 10.5 & 16 & 5.80 & 8.20 & 9.30 \\
\hline 07105530 & Main & 34 & 7.90 & 9.60 & 10.8 & 37 & 6.20 & 7.90 & 9.60 & 23 & 6.80 & 8.00 & 10.4 \\
\hline 07105600 & Trib & 2 & 10.3 & 10.5 & 10.6 & 12 & 5.30 & 7.60 & 9.20 & 6 & 7.20 & 8.00 & 9.60 \\
\hline 07105800 & Main & 35 & 7.30 & 9.60 & 11.2 & 42 & 6.10 & 7.50 & 10.0 & 12 & 6.00 & 8.30 & 9.10 \\
\hline \multicolumn{14}{|c|}{ Biological oxygen demand (mg/L) } \\
\hline 07103700 & Main & 1 & 3.40 & 3.40 & 3.40 & -- & -- & -- & -- & 1 & 13.0 & 13.0 & 13.0 \\
\hline 07103707 & Main & 1 & 2.00 & 2.00 & 2.00 & 2 & 1.60 & 2.95 & 4.30 & -- & -- & -- & -- \\
\hline 385854104470100 & Trib & -- & -- & -- & -- & -- & -- & -- & -- & -- & -- & -- & -- \\
\hline 07103960 & Trib & -- & -- & -- & -- & -- & -- & -- & -- & -- & -- & -- & -- \\
\hline 385750104475001 & Trib & -- & -- & -- & -- & -- & -- & -- & -- & -- & -- & -- & -- \\
\hline 07103970 & Main & 2 & 2.00 & 6.40 & 10.8 & -- & -- & -- & -- & 1 & 10.4 & 10.4 & 10.4 \\
\hline 07103977 & Trib & -- & -- & -- & -- & -- & -- & -- & -- & -- & - & -- & -- \\
\hline 07103985 & Trib & -- & -- & -- & -- & -- & -- & -- & -- & -- & -- & -- & -- \\
\hline 07103990 & Trib & -- & -- & -- & -- & -- & -- & -- & -- & -- & -- & -- & -- \\
\hline 07104050 & Trib & -- & -- & -- & -- & -- & -- & -- & -- & -- & -- & -- & -- \\
\hline 385501104483701 & Trib & -- & -- & -- & -- & -- & -- & -- & -- & -- & -- & -- & -- \\
\hline 385204104510101 & Trib & -- & -- & -- & -- & -- & -- & -- & -- & -- & -- & -- & -- \\
\hline 385124104501301 & Trib & -- & -- & -- & -- & -- & -- & -- & -- & -- & -- & -- & -- \\
\hline 07104905 & Main & 2 & 2.00 & 3.40 & 4.80 & -- & -- & -- & -- & 1 & 11.0 & 11.0 & 11.0 \\
\hline 07105000 & Trib & -- & - & -- & -- & -- & -- & -- & -- & -- & -- & -- & -- \\
\hline 384909104504401 & Trib & -- & -- & -- & -- & -- & -- & -- & -- & -- & -- & -- & -- \\
\hline 07105500 & Main & 1 & 4.30 & 4.30 & 4.30 & -- & -- & -- & -- & 1 & 3.40 & 3.40 & 3.40 \\
\hline 07105530 & Main & 3 & 6.10 & 6.10 & 8.30 & 2 & 5.30 & 5.80 & 6.30 & -- & -- & -- & -- \\
\hline 07105600 & Trib & -- & -- & -- & -- & -- & -- & - & -- & -- & -- & -- & -- \\
\hline 07105800 & Main & 3 & 7.50 & 9.60 & 10.0 & 2 & 2.40 & 3.70 & 5.00 & 1 & 7.40 & 7.40 & 7.40 \\
\hline
\end{tabular}




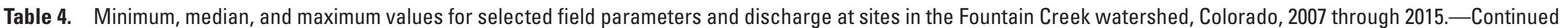

[USGS, U.S. Geological Survey; Main, main-stem site; Trib, tributary site; $\mu \mathrm{S} / \mathrm{cm}$, microsiemens per centimeter; mg/L, milligrams per liter; N, number of samples; CaCO ${ }_{3}$, calcium carbonate; --, no value]

\begin{tabular}{|c|c|c|c|c|c|c|c|c|c|c|c|c|c|}
\hline \multirow{2}{*}{$\begin{array}{c}\text { USGS } \\
\text { site number }\end{array}$} & \multirow{2}{*}{$\begin{array}{l}\text { Site } \\
\text { type }\end{array}$} & \multicolumn{4}{|c|}{ Cold-season flow } & \multicolumn{4}{|c|}{ Warm-season flow } & \multicolumn{4}{|c|}{ Stormflow } \\
\hline & & $\mathbf{N}$ & Minimum & Median & Maximum & $\mathbf{N}$ & Minimum & Median & Maximum & $\mathbf{N}$ & Minimum & Median & Maximum \\
\hline \multicolumn{14}{|c|}{ Hardness (mg/L as $\mathrm{CaCO}_{3}$ ) } \\
\hline 07103700 & Main & 11 & 70.6 & 123 & 211 & 23 & 57.2 & 123 & 216 & 21 & 35.6 & 69.2 & 215 \\
\hline 07103707 & Main & 10 & 140 & 186 & 331 & 36 & 52.9 & 144 & 911 & -- & -- & -- & -- \\
\hline 385854104470100 & Trib & -- & -- & -- & -- & -- & -- & -- & -- & -- & -- & -- & -- \\
\hline 07103960 & Trib & -- & -- & -- & -- & -- & -- & -- & -- & -- & -- & -- & -- \\
\hline 385750104475001 & Trib & -- & -- & -- & -- & -- & -- & -- & -- & -- & -- & -- & -- \\
\hline 07103970 & Main & 11 & 108 & 155 & 203 & 23 & 94.1 & 150 & 214 & 21 & 23.8 & 43.1 & 127 \\
\hline 07103977 & Trib & -- & -- & -- & -- & -- & -- & -- & -- & -- & -- & -- & -- \\
\hline 07103985 & Trib & -- & -- & -- & -- & -- & -- & -- & -- & -- & -- & -- & -- \\
\hline 07103990 & Trib & -- & -- & -- & -- & -- & -- & -- & -- & -- & -- & -- & -- \\
\hline 07104050 & Trib & -- & -- & -- & -- & -- & -- & -- & -- & -- & -- & -- & -- \\
\hline 385501104483701 & Trib & -- & -- & -- & -- & -- & -- & -- & -- & -- & -- & -- & -- \\
\hline 385204104510101 & Trib & -- & -- & -- & -- & -- & -- & -- & -- & -- & -- & -- & -- \\
\hline 385124104501301 & Trib & -- & -- & -- & -- & -- & -- & -- & -- & -- & -- & -- & -- \\
\hline 07104905 & Main & 10 & 139 & 192 & 247 & 24 & 113 & 193 & 280 & 15 & 46.9 & 72.8 & 158 \\
\hline 07105000 & Trib & -- & -- & -- & -- & -- & -- & -- & -- & -- & -- & -- & -- \\
\hline 384909104504401 & Trib & -- & -- & -- & -- & -- & -- & -- & -- & -- & -- & -- & -- \\
\hline 07105500 & Main & 13 & 182 & 209 & 288 & 30 & 99.0 & 191 & 268 & 18 & 48.7 & 97.3 & 223 \\
\hline 07105530 & Main & 10 & 162 & 180 & 202 & 24 & 131 & 176 & 232 & 20 & 38.2 & 80 & 158 \\
\hline 07105600 & Trib & -- & -- & -- & -- & -- & -- & -- & -- & -- & -- & -- & -- \\
\hline 07105800 & Main & 10 & 197 & 226 & 235 & 25 & 125 & 209 & 294 & 13 & 62 & 127 & 176 \\
\hline \multicolumn{14}{|c|}{ Alkalinity (mg/L as $\left.\mathrm{CaCO}_{3}\right)$} \\
\hline 07103700 & Main & 1 & 130 & 130 & 130 & 8 & 45.9 & 108 & 147 & 1 & 698 & 698 & 698 \\
\hline 07103707 & Main & 1 & 168 & 168 & 168 & 9 & 49.5 & 106 & 643 & -- & -- & -- & -- \\
\hline 385854104470100 & Trib & -- & -- & -- & -- & -- & -- & -- & -- & -- & -- & -- & -- \\
\hline 07103960 & Trib & -- & -- & -- & -- & -- & -- & -- & -- & -- & -- & -- & -- \\
\hline 385750104475001 & Trib & -- & -- & -- & -- & -- & -- & -- & -- & -- & -- & -- & -- \\
\hline 07103970 & Main & 1 & 106 & 106 & 106 & 7 & 73.0 & 106 & 127 & 1 & 39.8 & 39.8 & 39.8 \\
\hline 07103977 & Trib & -- & -- & -- & -- & -- & -- & -- & -- & -- & -- & -- & -- \\
\hline 07103985 & Trib & -- & -- & -- & -- & -- & -- & -- & -- & -- & -- & -- & -- \\
\hline 07103990 & Trib & -- & -- & -- & -- & -- & -- & -- & -- & -- & -- & -- & -- \\
\hline 07104050 & Trib & -- & -- & -- & -- & -- & -- & -- & -- & -- & -- & -- & -- \\
\hline 385501104483701 & Trib & -- & -- & -- & -- & -- & -- & -- & -- & -- & -- & -- & -- \\
\hline 385204104510101 & Trib & -- & -- & -- & -- & -- & -- & -- & -- & -- & -- & -- & -- \\
\hline 385124104501301 & Trib & -- & -- & -- & -- & -- & -- & -- & -- & -- & -- & -- & -- \\
\hline 07104905 & Main & 1 & 122 & 122 & 122 & 8 & 52.6 & 114 & 133 & -- & -- & -- & -- \\
\hline 07105000 & Trib & -- & -- & -- & -- & -- & -- & -- & -- & -- & -- & -- & -- \\
\hline 384909104504401 & Trib & -- & -- & -- & -- & -- & -- & -- & -- & -- & -- & -- & -- \\
\hline 07105500 & Main & 1 & 143 & 143 & 143 & 8 & 52.8 & 113 & 139 & -- & -- & -- & -- \\
\hline 07105530 & Main & 1 & 104 & 104 & 104 & 7 & 65.3 & 101 & 114 & 1 & 100 & 100 & 100 \\
\hline 07105600 & Trib & -- & -- & -- & -- & -- & -- & -- & -- & -- & - & -- & -- \\
\hline 07105800 & Main & 1 & 132 & 132 & 132 & 7 & 60.5 & 116 & 139 & 1 & 109 & 109 & 109 \\
\hline
\end{tabular}




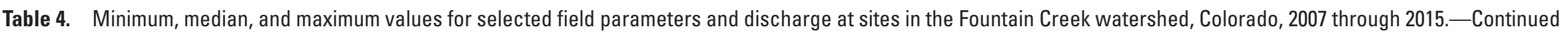
[USGS, U.S. Geological Survey; Main, main-stem site; Trib, tributary site; $\mu \mathrm{S} / \mathrm{cm}$, microsiemens per centimeter; mg/L, milligrams per liter; N, number of samples; CaCO${ }_{3}$, calcium carbonate; --, no value]

\begin{tabular}{|c|c|c|c|c|c|c|c|c|c|c|c|c|c|}
\hline \multirow{2}{*}{$\begin{array}{c}\text { USGS } \\
\text { site number }\end{array}$} & \multirow{2}{*}{$\begin{array}{l}\text { Site } \\
\text { type }\end{array}$} & \multicolumn{4}{|c|}{ Cold-season flow } & \multicolumn{4}{|c|}{ Warm-season flow } & \multicolumn{4}{|c|}{ Stormflow } \\
\hline & & $\mathbf{N}$ & Minimum & Median & Maximum & $\mathbf{N}$ & Minimum & Median & Maximum & $\mathbf{N}$ & Minimum & Median & Maximum \\
\hline \multicolumn{14}{|c|}{ Instantaneous discharge (cubic feet per second) } \\
\hline 07103700 & Main & 101 & 3.10 & 10.0 & 40.0 & 96 & 2.70 & 9.90 & 263 & 37 & 8.10 & 25.0 & 624 \\
\hline 07103707 & Main & 33 & 2.00 & 9.10 & 19.0 & 62 & 0.140 & 14.0 & 480 & -- & -- & -- & -- \\
\hline 385854104470100 & Trib & -- & -- & -- & -- & 5 & 0.610 & 1.70 & 13.0 & 1 & 2.50 & 2.50 & 2.50 \\
\hline 07103960 & Trib & 2 & 0.260 & 0.465 & 0.670 & 18 & 0.100 & 0.880 & 340 & 1 & 6.00 & 6.00 & 6.00 \\
\hline 385750104475001 & Trib & -- & -- & -- & -- & 6 & 1.10 & 1.60 & 20.0 & -- & -- & -- & -- \\
\hline 07103970 & Main & 112 & 7.30 & 16.0 & 148 & 117 & 4.40 & 15.0 & 161 & 104 & 9.60 & 280 & 1770 \\
\hline 07103977 & Trib & -- & -- & -- & -- & 4 & 0.010 & 0.130 & 0.400 & 2 & 1.50 & 2.65 & 3.80 \\
\hline 07103985 & Trib & -- & -- & -- & -- & 6 & 0.900 & 1.60 & 6.20 & -- & -- & -- & -- \\
\hline 07103990 & Trib & 33 & 2.40 & 4.10 & 7.90 & 81 & 1.80 & 4.80 & 18.0 & 44 & 10.0 & 198 & 1190 \\
\hline 07104050 & Trib & -- & -- & -- & -- & 4 & 0.010 & 0.040 & 0.060 & 2 & 2.60 & 13.8 & 25.0 \\
\hline 385501104483701 & Trib & -- & -- & -- & -- & 2 & 0.010 & 0.015 & 0.020 & -- & -- & -- & -- \\
\hline 385204104510101 & Trib & -- & -- & -- & -- & 4 & 0.300 & 0.740 & 1.40 & 1 & 2.80 & 2.80 & 2.80 \\
\hline 385124104501301 & Trib & 2 & 0.580 & 0.790 & 1.00 & 18 & 0.300 & 0.750 & 2.60 & 3 & 1.20 & 2.50 & 3.60 \\
\hline 07104905 & Main & 74 & 14.0 & 32.5 & 99.0 & 77 & 9.60 & 36.0 & 525 & 95 & 26.0 & 476 & 2500 \\
\hline 07105000 & Trib & -- & -- & -- & -- & 6 & 0.960 & 1.80 & 8.30 & -- & -- & -- & -- \\
\hline 384909104504401 & Trib & 2 & 0.700 & 0.950 & 1.20 & 19 & 0.040 & 1.30 & 26.0 & -- & -- & -- & -- \\
\hline 07105500 & Main & 134 & 15.0 & 45.0 & 237.0 & 122 & 14.0 & 46.5 & 907 & 102 & 41.0 & 585 & 4910 \\
\hline 07105530 & Main & 59 & 36.0 & 84.0 & 415 & 75 & 39.0 & 110 & 1420 & 49 & 104 & 1070 & 7800 \\
\hline 07105600 & Trib & 13 & 0.400 & 1.90 & 18.0 & 41 & 0.100 & 1.90 & 11.0 & 53 & 5.50 & 207 & 3040 \\
\hline 07105800 & Main & 140 & 41.0 & 81.0 & 411 & 148 & 39.0 & 87.0 & 1580.0 & 107 & 119 & 1620 & 8140 \\
\hline
\end{tabular}




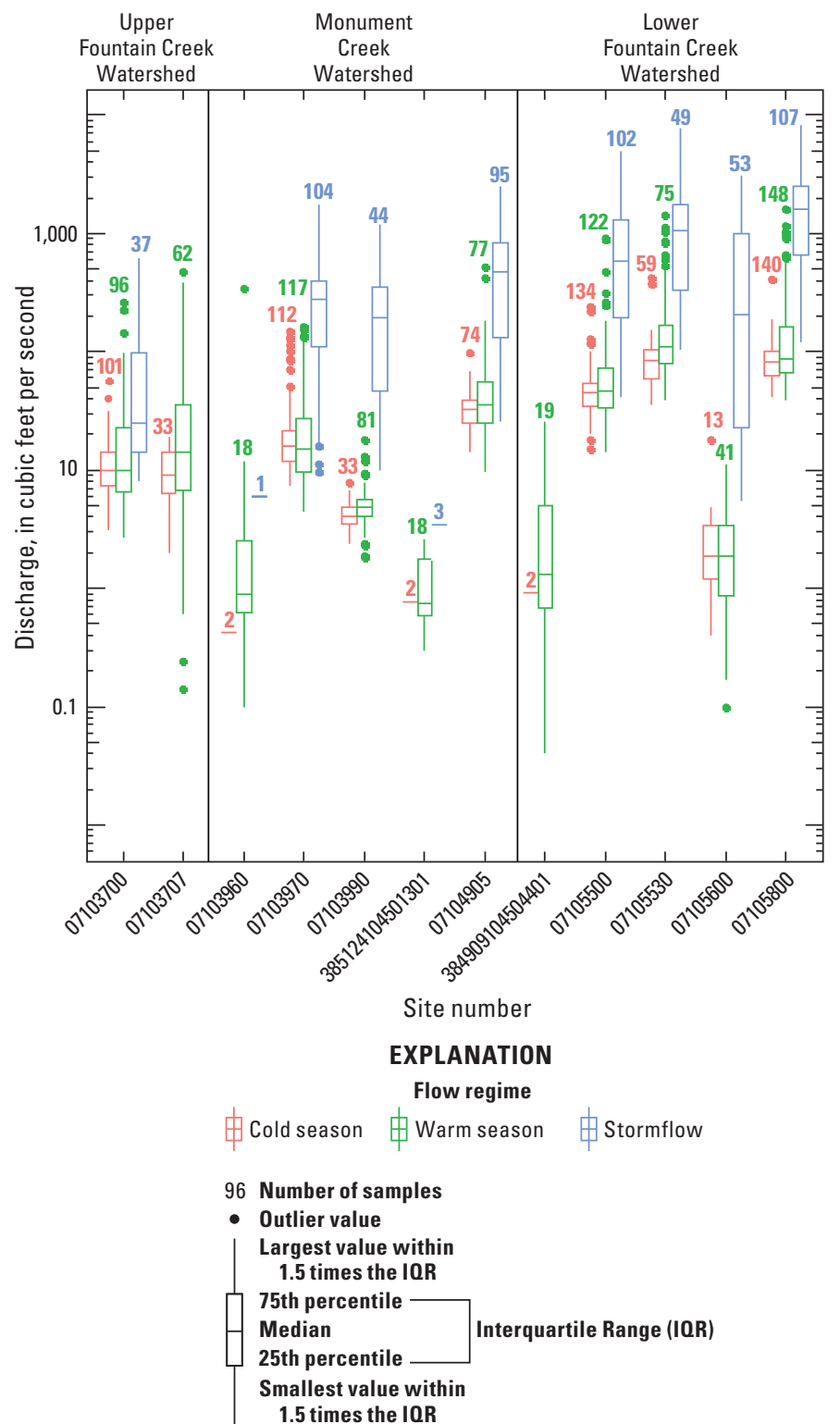

Figure 4. Variations in sampled streamflow at $A$, main-stem sites and $B$, tributary sites for cold-season flow, warmseason flow, and stormflow in Fountain and Monument Creek watersheds, Colorado, 2007 through 2015.

\section{Bacteria}

E. coli concentrations were lower in cold-season flow samples than in warm-season flow and stormflow samples and concentrations increased in the downstream direction, particularly during warm-season flows (fig. 6). Median cold-season flow E. coli concentrations ranged from $63 \mathrm{col} / 100 \mathrm{~mL}$ at site 07103700 (FoCr_Manitou) to $80 \mathrm{col} / 100 \mathrm{~mL}$ at site 07103707 (FoCr_8th); and median warm-season flow concentrations ranged from $410 \mathrm{col} / 100 \mathrm{~mL}$ at site 07103700 (FoCr_Manitou) to 1,350 at site 07103707 (FoCr_8th) (table 5; fig. 6). Median warm-season flow concentrations at the two main-stem sites

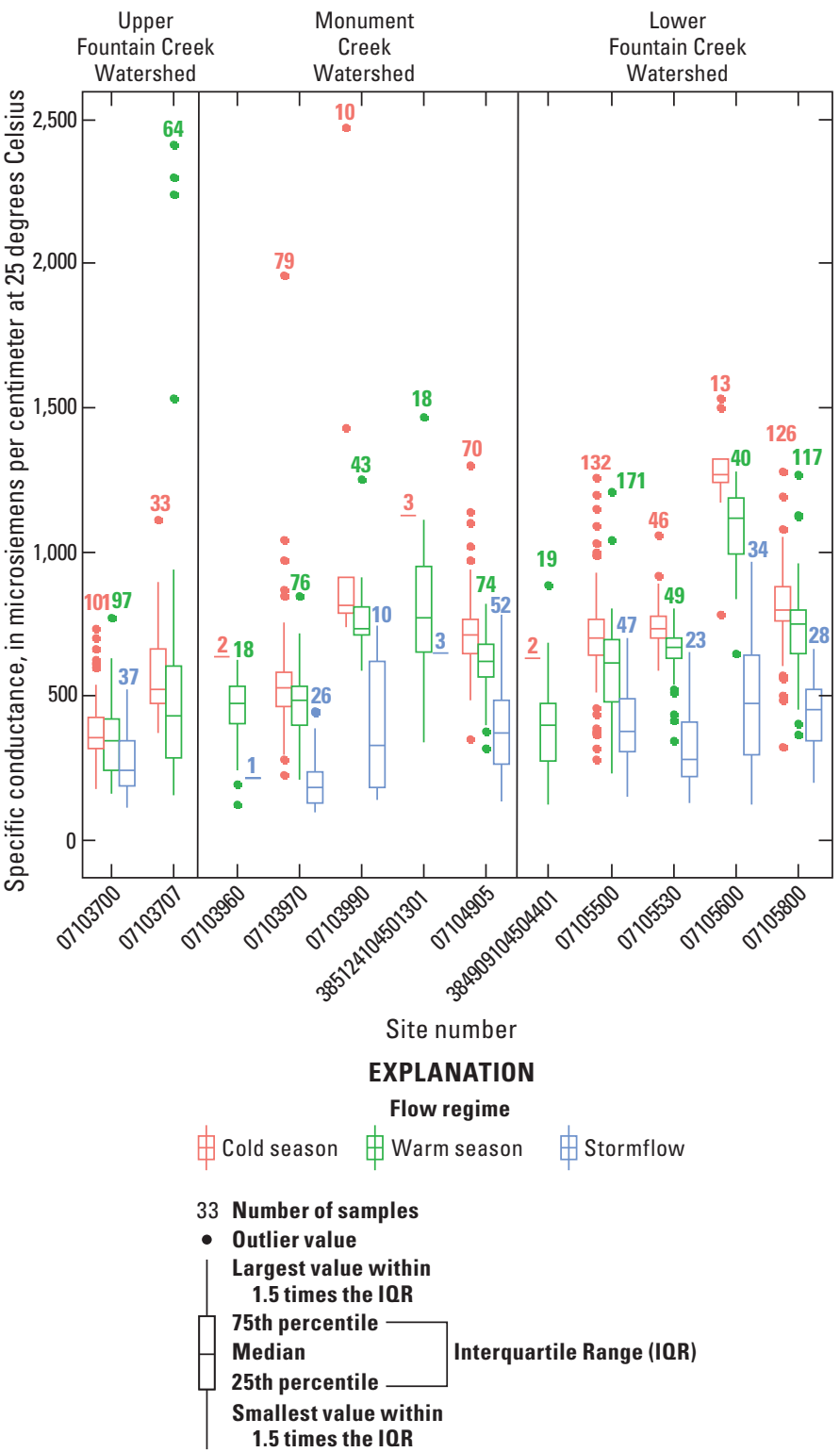

Figure 5. Variations in specific conductance at $A$, mainstem sites and $B$, tributary sites for cold-season flow, warmseason flow, and stormflow in Fountain and Monument Creek watersheds, Colorado, 2007 through 2015.

exceeded the recreational use standard of $126 \mathrm{col} / 100 \mathrm{~mL}$ for E. coli. The median E. coli stormflow concentration of $1,800 \mathrm{col} / 100 \mathrm{~mL}$ at site 07103700 (FoCr_Manitou) was more than 14 times higher than the recreational use standard (table 5). Concentrations of E. coli measured in samples from dry weather sites in the Upper Fountain Creek watershed ranged from 8 to $310 \mathrm{col} / 100 \mathrm{~mL}$ (table 6). The highest concentrations were measured during the lowest flows. Two of the four samples collected at site 385116104523301 (Fountain Creek at South 32nd Street) had concentrations that exceeded the standard. Concentrations of $E$. coli measured in samples at site 385108104522001 (Camp Creek at South 31st Street) 
Table 5. Minimum, median, and maximum Escherichia coli and suspended-sediment concentrations in cold-season flow, warm-season flow, and stormflow samples at selected sites in the Fountain Creek watershed, 2007-2015.

[Main, main-stem site; Trib, tributary site; mL, milliliter; N, number of samples; E, estimated value; <, less than the value shown; >, greater than the value shown]

\begin{tabular}{|c|c|c|c|c|c|c|c|c|c|c|c|c|c|}
\hline \multirow{2}{*}{ USGS site number } & \multirow{2}{*}{$\begin{array}{l}\text { Site } \\
\text { type }\end{array}$} & \multicolumn{4}{|c|}{ Cold-season flow } & \multicolumn{4}{|c|}{ Warm-season flow } & \multicolumn{4}{|c|}{ Storm flow } \\
\hline & & $\mathbf{N}$ & Minimum & Median & Maximum & $\mathbf{N}$ & Minimum & Median & Maximum & $\mathbf{N}$ & Minimum & Median & Maximum \\
\hline \multicolumn{14}{|c|}{ Escherichia coli (most probable number per $100 \mathrm{~mL}$ of water) } \\
\hline 07103700 & Main & 77 & 4 & 63 & $>2,400$ & 84 & 9 & 410 & 3,500 & 34 & 13 & 1,800 & 52,000 \\
\hline 07103707 & Main & 23 & 12 & 80 & $>2,400$ & 58 & 60 & 1,350 & 61,000 & -- & -- & -- & -- \\
\hline 385854104470100 & Trib & -- & -- & -- & -- & 2 & 37 & 48 & 59 & 1 & 7,300 & 7,300 & 7,300 \\
\hline 07103960 & Trib & -- & -- & -- & -- & 9 & 32 & 370 & E39,000 & 1 & 3,900 & 3,900 & 3,900 \\
\hline 385750104475001 & Trib & -- & -- & -- & -- & 3 & 93 & 610 & 6,600 & -- & -- & -- & -- \\
\hline 07103970 & Main & 56 & 2 & 41 & $>2,400$ & 63 & 1 & 100 & 2,000 & 19 & 160 & 9,200 & 37,000 \\
\hline 07103977 & Trib & -- & -- & -- & -- & 2 & 20 & 1,660 & 3,300 & 1 & 2,100 & 2,100 & 2,100 \\
\hline 07103985 & Trib & -- & -- & -- & -- & 3 & 20 & 66 & 8,200 & -- & -- & -- & -- \\
\hline 07103990 & Trib & 9 & 2 & 5 & 56 & 37 & 20 & 160 & 2,400 & 8 & 0 & 3,850 & 33,000 \\
\hline 07104050 & Trib & -- & -- & -- & -- & 2 & 920 & 1,110 & 1,300 & 1 & 6,400 & 6,400 & 6,400 \\
\hline 385204104510101 & Trib & -- & -- & -- & -- & 2 & 7 & 174 & 340 & 1 & 2,000 & 2,000 & 2,000 \\
\hline 385124104501301 & Trib & -- & -- & -- & -- & 7 & 34 & 360 & 1,100 & 2 & 7,300 & 9,150 & 11,000 \\
\hline 07104905 & Main & 43 & 18 & 61 & 690 & 46 & 30 & 390 & 2,600 & 15 & 93 & 4,600 & 49,000 \\
\hline 07105000 & Trib & -- & -- & -- & -- & 3 & 11 & 12 & 2,000 & -- & -- & -- & -- \\
\hline 384909104504401 & Trib & -- & -- & -- & -- & 10 & 28 & 225 & 13,000 & -- & -- & -- & -- \\
\hline 07105500 & Main & 80 & 7 & 58 & 2,000 & 77 & 22 & 440 & 2,900 & 20 & 22 & 4,750 & 77,000 \\
\hline 07105530 & Main & 43 & 26 & 100 & 330 & 45 & 47 & 330 & 2,600 & 21 & 300 & 11,000 & 58,000 \\
\hline 07105600 & Trib & 1 & 4 & 4 & 4 & 6 & 61 & 520 & 1,100 & 6 & 140 & 5,850 & 14,000 \\
\hline 07105800 & Main & 81 & 5 & 43 & $>2,400$ & 82 & 2 & 160 & 6,500 & 13 & 100 & 8,800 & 92,000 \\
\hline \multicolumn{14}{|c|}{ Suspended sediment (mg/L) } \\
\hline 07103700 & Main & 11 & 2 & 9 & 36 & 23 & 2 & 17 & 1,020 & 20 & 6 & 3,925 & 155,000 \\
\hline 07103707 & Main & 7 & 2 & 26 & 161 & 25 & 1 & 24 & 51,300 & -- & -- & -- & -- \\
\hline 385854104470100 & Trib & -- & -- & -- & -- & -- & -- & -- & -- & -- & -- & -- & -- \\
\hline 07103960 & Trib & -- & -- & -- & -- & 12 & 0.5 & 66 & 10,600 & 1 & 3,970 & 3,970 & 3,970 \\
\hline 385750104475001 & Trib & -- & -- & -- & -- & -- & -- & -- & -- & -- & -- & -- & -- \\
\hline 07103970 & Main & 69 & 6 & 145 & 20,300 & 577 & 4 & 1,480 & 24,800 & 95 & 38 & 1,310 & 10,300 \\
\hline 07103977 & Trib & -- & -- & -- & -- & -- & -- & -- & -- & -- & -- & -- & -- \\
\hline 07103985 & Trib & -- & -- & -- & -- & -- & -- & -- & -- & -- & -- & -- & -- \\
\hline 07103990 & Trib & 41 & 28 & 394 & 7,460 & 148 & 14 & 2,375 & 20,100 & 41 & 97 & 8,050 & 26,400 \\
\hline 07104050 & Trib & & & & & -- & -- & -- & -- & -- & -- & -- & -- \\
\hline 385204104510101 & Trib & & & & & -- & -- & -- & -- & -- & -- & -- & -- \\
\hline 385124104501301 & Trib & -- & -- & -- & -- & 9 & 6 & 57 & 118 & 3 & 384 & 549 & 968 \\
\hline 07104905 & Main & 71 & 7 & 614 & 6,260 & 145 & 7 & 2,960 & 7,360 & 92 & 18 & 2,580 & 9,760 \\
\hline 07105000 & Trib & & & & & -- & -- & -- & -- & -- & -- & -- & -- \\
\hline 384909104504401 & Trib & -- & -- & -- & -- & 14 & 3 & 32 & 2,970 & -- & -- & -- & -- \\
\hline 07105500 & Main & 67 & 9 & 240 & 13,100 & 189 & 3 & 4,170 & 56,900 & 86 & 38 & 2,860 & 21,300 \\
\hline 07105530 & Main & 22 & 9 & 29 & 286 & 427 & 7 & 2,490 & 24,500 & 42 & 77 & 2,145 & 8,810 \\
\hline 07105600 & Trib & 10 & 34 & 202 & 1,820 & 50 & 0.5 & 182 & 14,100 & 52 & 60 & 3,075 & 12,200 \\
\hline 07105800 & Main & 54 & 14 & 95 & 5,030 & 516 & 11 & 3,195 & 36,300 & 104 & 137 & 3,000 & 13,000 \\
\hline
\end{tabular}




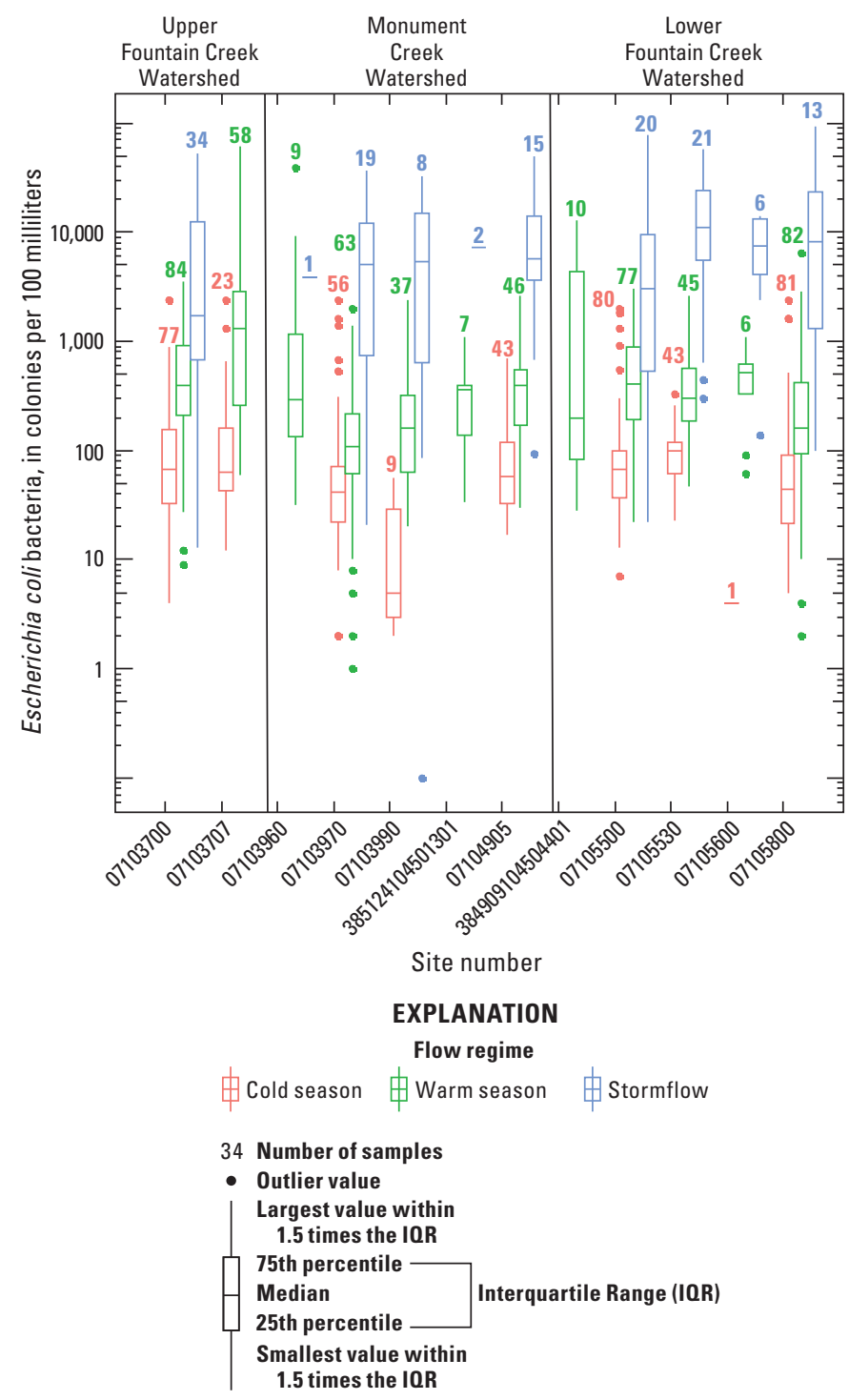

Figure 6. Variations in Escherichia coli (E. coli) for cold-season flow, warm-season flow, and stormflow at sites in Fountain and Monument Creek watersheds, Colorado, 2007 through 2015.

were well below the water-quality standard of $126 \mathrm{col} / 100 \mathrm{~mL}$ (table 6). The elevated concentrations of E. coli within the Upper Fountain Creek watershed during warm-season flows and stormflows may be because of runoff from urban and suburban areas, areas with domestic livestock, and possibly, input from onsite wastewater treatment systems.

\section{Nutrients}

Dissolved-ammonia concentrations ranged from less than 0.01 to $1.67 \mathrm{mg} / \mathrm{L}$, nitrate plus nitrite concentrations ranged from 0.127 to $13.2 \mathrm{mg} / \mathrm{L}$, and total phosphorus concentrations ranged from less than 0.02 to $71.3 \mathrm{mg} / \mathrm{L}$ in samples from main-stem sites along Upper Fountain Creek (07103700 and 07103707; table 7). Median dissolved-ammonia concentrations in cold-season flows and warm-season flows at sites 07103700 (FoCr_Manitou) and 07103707 (FoCr_8th) were low, $0.02 \mathrm{mg} / \mathrm{L}$ or less. Median nitrate plus nitrite concentrations were less than $1 \mathrm{mg} / \mathrm{L}$ for all flow regimes (fig. 7). Ninety-five percent of samples had concentrations of total phosphorus less than $5 \mathrm{mg} / \mathrm{L}$. Median concentrations of total phosphorus ranged from $0.02 \mathrm{mg} / \mathrm{L}$ during cold-season flow to $1.96 \mathrm{mg} / \mathrm{L}$ during stormflows. Runoff from the Waldo Canyon fire burn area appeared to increase nutrient concentrations in some warmseason flow and stormflow samples in Upper Fountain Creek after June 2012. The maximum concentrations of dissolved ammonia $(1.67 \mathrm{mg} / \mathrm{L})$, nitrate plus nitrite $(13.2 \mathrm{mg} / \mathrm{L})$, and total phosphorus $(71.3 \mathrm{mg} / \mathrm{L})$ were measured in a single stormflow sample collected July 1, 2013. Concentrations of nitrate plus nitrite greater than $1.5 \mathrm{mg} / \mathrm{L}$ and total phosphorus concentrations greater than $5 \mathrm{mg} / \mathrm{L}$ were only measured in Upper Fountain Creek samples collected after the Waldo Canyon fire. One concentration of nitrate plus nitrite, $13.2 \mathrm{mg} / \mathrm{L}$, measured in a stormflow sample collected at 07103700 (FoCr_Manitou) exceeded the in-stream water-quality standard of $10 \mathrm{mg} / \mathrm{L}$.

\section{Nutrient Loads}

Instantaneous nutrient loads in stormflow were considerably larger than cold-season flow and warm-season flow loads (fig. 8). In Upper Fountain Creek at site 07103700 (FoCr_Manitou) during 2007-2015, median dissolved ammonia loads ranged from about $0.6 \mathrm{lb} / \mathrm{d}$ during warmseason flow to about $44 \mathrm{lb} / \mathrm{d}$ during stormflow. Median total phosphorus loads at the same location ranged from less than $2.0 \mathrm{lb} / \mathrm{d}$ during cold-season flow to $1,560 \mathrm{lb} / \mathrm{d}$ during stormflow, and median nitrate plus nitrite loads ranged from $33 \mathrm{lb} / \mathrm{d}$ during warm-season flow to $288 \mathrm{lb} / \mathrm{d}$ during stormflow. Median stormflow loads of dissolved ammonia and total phosphorus were substantially lower in Upper Fountain Creek at site 07103700 (FoCr_Manitou) during 1998-2006 than during 2007-2015. During 1998-2006, the median dissolved ammonia load during stormflow was $16 \mathrm{lb} / \mathrm{d}$ (less than half the 2007-2015 median of $44 \mathrm{lb} / \mathrm{d}$ ), and the median total phosphorus load was $275 \mathrm{lb} / \mathrm{d}$ (about five times less than the 2007-2015 median of 1,560 lb/d) during stormflow (Mau and others, 2007). The increase in median stormflow loads during 2007-2015 may be because concentrations of nutrients increased in streamflow after the Waldo Canyon fire in 2012 and, as a result, nutrient loads increased. In addition, stormflow loads may have increased because of active development in the Gold Hill Mesa area. Land development typically alters ground cover, which can change runoff characteristics.

\section{Trace Elements}

Concentrations of trace elements varied by site and by flow regime. Increases (from 1.5 to 28.5 times higher) in median total arsenic, total copper, total lead, dissolved and total manganese, total nickel, dissolved and total selenium, and dissolved and total zinc concentrations occurred during 
Table 6. Instantaneous flow and Escherichia coli concentrations at dry weather sites during 2015.

[Dry weather site number, number shown on figure 1; USGS, U.S. Geological Survey; gal/min, gallons per minute; col, colonies; mL, milliliter; N, number of samples; --, no data; E, estimated value; <, less than the value shown; >, greater than the value shown]

\begin{tabular}{|c|c|c|c|c|c|c|c|c|c|c|}
\hline \multirow{2}{*}{$\begin{array}{c}\text { Dry } \\
\text { weather } \\
\text { site } \\
\text { number }\end{array}$} & \multirow{2}{*}{$\begin{array}{c}\text { USGS } \\
\text { site number }\end{array}$} & \multirow[b]{2}{*}{ USGS site name } & \multicolumn{4}{|c|}{ Instantaneous flow (gal/min) } & \multicolumn{4}{|c|}{ E. coli $(\mathrm{col} / 100 \mathrm{~mL})$} \\
\hline & & & $\mathbf{N}$ & Min & Max & Avg & $\mathbf{N}$ & Min & Max & Avg \\
\hline \multicolumn{11}{|c|}{ Upper Fountain Creek } \\
\hline 2 & 385116104523301 & Fountain Creek at South 32nd Street near Colorado Springs (culvert) & 4 & 0 & 27 & 13.5 & 4 & 8 & 310 & 154 \\
\hline 3 & 385108104522001 & Camp Creek at South 31st Street near Colorado Springs & 4 & 76 & 7,630 & 2,065 & 4 & 8 & 52 & 22 \\
\hline \multicolumn{11}{|c|}{ Monument Creek } \\
\hline 5 & 390121104482601 & Monument Creek tributary near Diamond Rim Drive near Colorado Springs & 4 & 36 & 323 & 189 & 4 & $<1$ & 460 & 129 \\
\hline 8 & 385759104453001 & Pine Creek drain at North Union Boulevard North Park at Colorado Springs & 4 & 9.0 & 583 & 274 & 4 & $<1$ & 160 & 98 \\
\hline 9 & 385812104462601 & Pine Creek drain at Pine Creek Golf Club at Colorado Springs & 4 & 126 & 673 & 431 & 4 & 29 & 210 & 89 \\
\hline 10 & 385756104474501 & Pine Creek drain Briargate Parkway at Colorado Springs (culvert) & 4 & 9.0 & 27 & 18.0 & 4 & 170 & 1,400 & 820 \\
\hline 12 & 385640104481501 & South Pine Creek (culvert 2 aqueduct) at Goddard Street at Colorado Springs & 4 & 9.0 & 22 & 18.0 & 4 & 390 & $>2,400$ & 1,898 \\
\hline 15 & 385642104433901 & Cottonwood Creek tributary at Potomac Drive at Colorado Springs & 4 & 13 & 31 & 27 & 4 & 1 & 260 & 95 \\
\hline 16 & 385548104443301 & Cottonwood Creek drain at Austin Bluffs Parkway, Colorado Springs & 4 & 13 & 36 & 22 & 4 & 22 & 84 & 47 \\
\hline 18 & 385549104451401 & Cottonwood Creek drain Rangewood Drive at Colorado Springs & 4 & 9.0 & 350 & 135 & 4 & 80 & $>2,400$ & 1,260 \\
\hline 19 & 385547104473601 & Cottonwood Creek drain at North Academy Boulevard near York Road & 4 & 18 & 45 & 36 & 4 & $<1$ & 12 & 4 \\
\hline 20 & 07103990 & Cottonwood Creek at mouth at Pikeview & 4 & 1,212 & 5,835 & 3,052 & 4 & 3 & 1,000 & 312 \\
\hline 23 & 385349104491201 & Monument Creek drain Pikeview Reservoir at Colorado Springs (culvert) & 4 & 22 & 130 & 71 & 4 & 2 & 10 & 7 \\
\hline 24 & 385321104493301 & Douglas Creek at the mouth at Colorado Springs, Colo. & 4 & 256 & 2,513 & 1,005 & 4 & 4 & 190 & 64 \\
\hline 25 & 385353104465301 & Templeton Gap floodway at North Union Boulevard at Colorado Springs & -- & -- & -- & -- & -- & -- & -- & -- \\
\hline 26 & 385307104494401 & Monument Creek drain 1 Mark Dabling Boulevard at Colorado Springs & 4 & 13 & 49 & 27 & 4 & $<1$ & 21 & 8 \\
\hline 27 & 385303104494601 & Monument Creek drain 2 Mark Dabling Boulevard at Colorado Springs & 4 & 18 & 58 & 45 & 4 & $<1$ & 230 & 62 \\
\hline 28 & 385259104500201 & Douglas Creek drain at Sinton Road at Colorado Springs (culvert) & 4 & 9.0 & 175 & 76 & 4 & $<1$ & 10 & 4 \\
\hline 29 & 385257104494401 & Douglas Creek South at mouth at Colorado Springs, Colo. & 4 & 278 & 987 & 718 & 4 & 16 & 230 & 107 \\
\hline 30 & 385242104495001 & Monument Creek drain 3 Mark Dabling Boulevard at Colorado Springs & 4 & 13 & 36 & 27 & 4 & $<1$ & 1 & 1 \\
\hline 31 & 385235104495101 & Monument Creek drain 4 Mark Dabling Boulevard at Colorado Springs & 4 & 40 & 58 & 49 & 4 & 68 & 200 & 150 \\
\hline 32 & 385203104494301 & Monument Creek aqueduct at Tremont Street at Colorado Springs & 4 & 31 & 45 & 40 & 4 & 12 & 1,300 & 397 \\
\hline 35 & 385124104495701 & Mesa Creek at mouth at Recreation Way at Colorado Springs & 4 & 171 & 449 & 314 & 4 & 91 & 510 & 205 \\
\hline \multicolumn{11}{|c|}{ Lower Fountain Creek } \\
\hline 38 & 384920104511201 & Bear Creek drain near Creek Crossing Street at Colorado Springs & 1 & 9.0 & 9.0 & 9.0 & 1 & 1,100 & 1,100 & 1,100 \\
\hline 40 & 384921104501001 & Bear Creek at Interstate 25 at Colorado Springs & 4 & 1,257 & 3,860 & 2,020 & 4 & 12 & 330 & 96 \\
\hline 41 & 384900104492801 & Fountain Creek drain at South Tejon Street at Colorado Springs (culvert) & 4 & 72 & 229 & 139 & 4 & 49 & $>2,400$ & 835 \\
\hline 43 & 384905104485901 & Shooks Run at Las Vegas Street at Colorado Springs & 4 & 166 & 628 & 395 & 6 & 55 & 380 & 221 \\
\hline 44 & 384823104501601 & Cheyenne Run tributary at Colorado Springs (culvert) & 4 & 4.5 & 72 & 27 & 4 & 550 & 8,200 & 3,612 \\
\hline 45 & 384959104481401 & Shooks Run tributary at Colorado Springs (culvert to ditch) & 4 & 4.5 & 13.5 & 9.0 & 4 & 130 & 2,800 & 1,405 \\
\hline 46 & 385014104454901 & Spring Creek drain at Auburn Drive at Colorado Springs (culvert) & 2 & E0.13 & E40 & E20 & 2 & $<1$ & $<10$ & -- \\
\hline 47 & 384930104453701 & Spring Creek drain Majorie Lee Drive near Airport Road at Colorado Springs & 4 & 27 & 117 & 76 & 4 & 110 & $>2,400$ & 725 \\
\hline 48 & 384833104473900 & Spring Creek downstream Las Vegas Street & 4 & 4,488 & 6,284 & 5,476 & 4 & 68 & 560 & 247 \\
\hline 50 & 384749104470801 & Fountain Creek drain near Circle Drive at Colorado Springs (culvert) & 4 & 9.0 & 18 & 13.5 & 4 & 1 & 19 & 10 \\
\hline 51 & 384701104465101 & Unnamed ditch to Fountain Creek below I-25 at Pond Colorado Springs & 4 & 9.0 & 144 & 72 & 4 & 2 & 110 & 34 \\
\hline 52 & 385255104440501 & Valencia Creek near Oro Blanco Drive at Colorado Springs (culvert) & 4 & 4.5 & 135 & 49 & 4 & $<1$ & 150 & 68 \\
\hline 53 & 385406104422001 & Sand Creek drain near Barnes Road at Colorado Springs (culvert) & 4 & 4.5 & 31 & 13.5 & 4 & 5 & 1,700 & 464 \\
\hline 54 & 385353104422501 & Sand Creek drain at Barnes Road at Colorado Springs (culvert) & 4 & 4.5 & 22 & 13.5 & 4 & 3 & $>2,400$ & 1,038 \\
\hline 55 & 385248104423501 & Sand Creek drain at Spring Ranch Golf Club at Colorado Springs & 4 & 9.0 & 27 & 18.0 & 4 & 17 & 610 & 223 \\
\hline 56 & 384917104443601 & Sand Creek drain near Crestline Drive at Colorado Springs (culvert) & -- & -- & -- & -- & -- & -- & -- & -- \\
\hline 57 & 384914104441501 & Sand Creek drain at Nolte Drive West at Colorado Springs (culvert) & -- & -- & -- & -- & -- & -- & -- & -- \\
\hline 58 & 07105600 & Sand Creek above mouth at Colorado Springs & 4 & 180 & 9,425 & 3,815 & 4 & 4 & 350 & 139 \\
\hline
\end{tabular}


Table 7. Minimum, median, and maximum concentrations for ammonia, nitrate plus nitrite, and phosphorus at sites in the Fountain Creek watershed, Colorado, 2007-2015.

[USGS, U.S. Geological Survey; Main, main-stem site; Trib, tributary site; mg/L, milligrams per liter; N, number of samples; E, estimated value; <, less than the value shown; --, no value]

\begin{tabular}{|c|c|c|c|c|c|c|c|c|c|c|c|c|c|}
\hline \multirow{2}{*}{$\begin{array}{c}\text { USGS } \\
\text { site number }\end{array}$} & \multirow{2}{*}{$\begin{array}{l}\text { Site } \\
\text { type }\end{array}$} & \multicolumn{4}{|c|}{ Cold-season flow } & \multicolumn{4}{|c|}{ Warm-season flow } & \multicolumn{4}{|c|}{ Stormflow } \\
\hline & & $\mathbf{N}$ & Minimum & Median & Maximum & $\mathbf{N}$ & Minimum & Median & Maximum & $\mathbf{N}$ & Minimum & Median & Maximum \\
\hline \multicolumn{14}{|c|}{ Ammonia in unfiltered water (mg/L as nitrogen) } \\
\hline 07103700 & Main & 30 & $<0.02$ & $<0.02$ & 0.08 & 26 & $<0.02$ & $<0.02$ & 0.04 & 8 & $<0.02$ & 0.23 & 1.64 \\
\hline 07103707 & Main & 2 & 0.02 & 0.055 & 0.09 & 7 & 0.02 & 0.02 & 0.46 & -- & -- & -- & -- \\
\hline 385854104470100 & Trib & -- & -- & -- & -- & -- & -- & -- & -- & -- & -- & -- & -- \\
\hline 07103960 & Trib & -- & -- & -- & -- & -- & -- & -- & -- & -- & -- & -- & -- \\
\hline 385750104475001 & Trib & -- & -- & -- & -- & -- & -- & -- & -- & -- & -- & - & -- \\
\hline 07103970 & Main & 1 & 0.03 & 0.03 & 0.03 & 3 & $<0.02$ & $<0.02$ & 0.03 & 5 & 0.19 & 0.41 & 0.79 \\
\hline 07103977 & Trib & -- & -- & -- & -- & -- & -- & -- & -- & -- & -- & -- & -- \\
\hline 07103985 & Trib & -- & - & - & -- & - & - & -- & -- & - & -- & - & -- \\
\hline 07103990 & Trib & - & -- & - & -- & - & - & -- & - & -- & -- & - & - \\
\hline 07104050 & Trib & -- & -- & -- & -- & -- & -- & -- & -- & -- & -- & -- & -- \\
\hline 385501104483701 & Trib & -- & -- & -- & -- & -- & -- & -- & -- & -- & -- & -- & -- \\
\hline 385204104510101 & Trib & -- & -- & -- & -- & -- & -- & -- & -- & -- & -- & -- & -- \\
\hline 385124104501301 & Trib & -- & -- & -- & -- & -- & -- & -- & -- & -- & -- & -- & -- \\
\hline 07104905 & Main & 29 & $<0.02$ & 0.08 & 0.72 & 29 & $<0.02$ & 0.06 & 0.20 & 3 & 0.28 & 0.57 & 1.52 \\
\hline 07105000 & Trib & -- & -- & -- & -- & -- & -- & -- & -- & -- & -- & -- & -- \\
\hline 384909104504401 & Trib & -- & -- & -- & -- & -- & -- & -- & -- & -- & -- & -- & -- \\
\hline 07105500 & Main & 30 & $<0.02$ & 0.04 & 1.08 & 28 & $<0.02$ & 0.03 & 0.51 & 4 & 0.04 & 0.22 & 0.54 \\
\hline 07105530 & Main & 29 & $<0.02$ & 0.05 & 0.80 & 27 & $<0.02$ & 0.05 & 0.28 & 8 & $<0.02$ & 0.25 & 0.87 \\
\hline 07105600 & Trib & -- & -- & -- & -- & -- & -- & -- & -- & -- & -- & -- & -- \\
\hline 07105800 & Main & 30 & 0.10 & 0.38 & 1.24 & 29 & $<0.02$ & 0.23 & 0.51 & 1 & 0.17 & 0.17 & 0.17 \\
\hline \multicolumn{14}{|c|}{ Ammonia in filtered water ( $\mathrm{mg} / \mathrm{L}$ as nitrogen) } \\
\hline 07103700 & Main & 11 & $<0.01$ & $<0.01$ & $<0.02$ & 23 & $<0.01$ & $<0.01$ & 0.02 & 21 & $<0.01$ & 0.04 & 1.67 \\
\hline 07103707 & Main & 13 & 0.02 & 0.02 & 0.05 & 38 & $<0.01$ & 0.02 & 0.61 & -- & -- & -- & -- \\
\hline 385854104470100 & Trib & -- & -- & -- & -- & 5 & $<0.02$ & $<0.02$ & $<0.02$ & 1 & 0.02 & 0.02 & 0.02 \\
\hline 07103960 & Trib & -- & -- & -- & -- & 12 & $<0.01$ & 0.02 & 1.17 & 1 & 0.12 & 0.12 & 0.12 \\
\hline 385750104475001 & Trib & -- & -- & -- & -- & 6 & E0.01 & E0.01 & 0.08 & -- & - & -- & -- \\
\hline 07103970 & Main & 11 & $<0.01$ & 0.02 & 0.60 & 23 & $<0.01$ & $<0.01$ & 0.03 & 21 & $<0.01$ & 0.13 & 0.62 \\
\hline 07103977 & Trib & - & -- & -- & -- & 4 & E0.01 & 0.02 & 0.05 & 2 & E0.01 & E0.02 & E0.02 \\
\hline 07103985 & Trib & -- & -- & -- & -- & 6 & E0.01 & 0.02 & 1.01 & -- & -- & $\begin{array}{c}20.0 \\
--\end{array}$ & -- \\
\hline 07103990 & Trib & -- & - & - & -- & 8 & $<0.01$ & E0.01 & $<0.02$ & 6 & 0.05 & 0.08 & 0.30 \\
\hline 07104050 & Trib & -- & - & - & -- & 4 & $<0.02$ & $<0.02$ & $<0.02$ & 2 & 0.06 & 0.25 & 0.44 \\
\hline 385501104483701 & Trib & -- & -- & -- & -- & 2 & 0.02 & 0.02 & 0.02 & -- & -- & -- & - \\
\hline 385204104510101 & Trib & -- & -- & -- & -- & 4 & E0.01 & 0.02 & 0.02 & 1 & 0.02 & 0.02 & 0.02 \\
\hline 385124104501301 & Trib & -- & -- & -- & -- & 9 & $<0.01$ & 0.02 & 0.02 & 3 & 0.01 & 0.02 & 0.07 \\
\hline 07104905 & Main & 7 & 0.02 & 0.12 & 0.23 & 15 & $<0.01$ & 0.03 & 0.69 & 15 & 0.02 & 0.12 & 0.47 \\
\hline 07105000 & Trib & -- & -- & -- & -- & 6 & $<0.02$ & $<0.02$ & E0.02 & -- & -- & -- & -- \\
\hline 384909104504401 & Trib & -- & -- & -- & -- & 13 & $<0.01$ & $<0.02$ & 0.16 & -- & -- & -- & -- \\
\hline 07105500 & Main & 9 & 0.02 & 0.07 & 0.25 & 14 & $<0.01$ & 0.02 & 0.46 & 15 & $<0.02$ & 0.11 & 0.43 \\
\hline 07105530 & Main & 10 & 0.02 & 0.10 & 0.30 & 24 & E0.01 & 0.04 & 0.59 & 20 & E0.01 & 0.22 & 0.58 \\
\hline 07105600 & Trib & -- & -- & -- & -- & 4 & $<0.01$ & 0.02 & 2.65 & 3 & 0.08 & 0.36 & 0.70 \\
\hline 07105800 & Main & 7 & 0.22 & 0.36 & 0.98 & 17 & 0.02 & 0.17 & 0.40 & 12 & E0.01 & 0.15 & 0.39 \\
\hline
\end{tabular}


Table 7. Minimum, median, and maximum concentrations for ammonia, nitrate plus nitrite, and phosphorus at sites in the Fountain Creek watershed, Colorado, 2007-2015. -Continued

[USGS, U.S. Geological Survey; Main, main-stem site; Trib, tributary site; mg/L, milligrams per liter; N, number of samples; E, estimated value; <, less than the value shown; --, no value]

\begin{tabular}{|c|c|c|c|c|c|c|c|c|c|c|c|c|c|}
\hline \multirow{2}{*}{$\begin{array}{c}\text { USGS } \\
\text { site number }\end{array}$} & \multirow{2}{*}{$\begin{array}{l}\text { Site } \\
\text { type }\end{array}$} & \multicolumn{4}{|c|}{ Cold-season flow } & \multicolumn{4}{|c|}{ Warm-season flow } & \multicolumn{4}{|c|}{ Stormflow } \\
\hline & & $\mathbf{N}$ & Minimum & Median & Maximum & $\mathbf{N}$ & Minimum & Median & Maximum & $\mathbf{N}$ & Minimum & Median & Maximum \\
\hline \multicolumn{14}{|c|}{ Nitrate plus nitrite in filtered water (mg/L as nitrogen) } \\
\hline 07103700 & Main & 11 & 0.420 & 0.880 & 1.10 & 23 & 0.310 & 0.612 & 1.68 & 21 & 0.360 & 0.660 & 13.2 \\
\hline 07103707 & Main & 13 & 0.690 & 0.810 & 1.05 & 38 & 0.127 & 0.625 & 2.79 & -- & -- & -- & -- \\
\hline 385854104470100 & Trib & -- & -- & -- & -- & 5 & 0.070 & 0.23 & 0.57 & 1 & 0.200 & 0.200 & 0.200 \\
\hline 07103960 & Trib & -- & -- & -- & -- & 12 & $<0.04$ & 0.27 & 0.86 & 1 & 0.390 & 0.390 & 0.390 \\
\hline 385750104475001 & Trib & -- & -- & -- & -- & 6 & 0.430 & 1.58 & 2.31 & -- & -- & -- & -- \\
\hline 07103970 & Main & 11 & 0.863 & 1.32 & 1.92 & 23 & 0.203 & 0.61 & 1.84 & 21 & 0.295 & 0.451 & 0.870 \\
\hline 07103977 & Trib & -- & -- & -- & -- & 4 & $<0.06$ & $<0.06$ & $<0.06$ & 2 & 0.10 & 0.20 & 0.30 \\
\hline 07103985 & Trib & -- & -- & -- & -- & 6 & 2.01 & 5.65 & 7.29 & -- & -- & -- & -- \\
\hline 07103990 & Trib & -- & -- & -- & -- & 8 & 2.54 & 3.89 & 5.41 & 6 & 0.440 & 0.698 & 1.65 \\
\hline 07104050 & Trib & -- & -- & -- & -- & 4 & 4.38 & 8.37 & 14.4 & 2 & 0.790 & 1.71 & 2.62 \\
\hline 385501104483701 & Trib & -- & -- & -- & -- & 2 & 0.54 & 1.34 & 2.14 & -- & -- & -- & -- \\
\hline 385204104510101 & Trib & -- & -- & -- & -- & 4 & 1.39 & 2.03 & 2.52 & 1 & 0.67 & 0.67 & 0.67 \\
\hline 385124104501301 & Trib & -- & -- & -- & -- & 9 & 1.11 & 1.47 & 1.86 & 3 & 0.57 & 0.72 & 0.80 \\
\hline 07104905 & Main & 7 & 1.75 & 2.80 & 4.33 & 15 & 0.89 & 3.68 & 5.52 & 15 & 0.51 & 1.13 & 2.98 \\
\hline 07105000 & Trib & -- & -- & -- & -- & 6 & $<0.04$ & 0.05 & 0.19 & -- & -- & -- & -- \\
\hline 384909104504401 & Trib & -- & -- & -- & -- & 13 & $<0.04$ & 0.42 & 1.01 & -- & -- & -- & -- \\
\hline 07105500 & Main & 10 & 1.46 & 2.23 & 3.32 & 21 & 1.33 & 2.35 & 4.41 & 18 & 0.56 & 0.86 & 2.94 \\
\hline 07105530 & Main & 10 & 2.76 & 3.39 & 5.98 & 24 & 1.26 & 3.37 & 5.78 & 20 & 0.48 & 1.09 & 2.92 \\
\hline 07105600 & Trib & -- & -- & -- & -- & 4 & 0.149 & 0.87 & 4.36 & 3 & 0.45 & 0.610 & 1.05 \\
\hline 07105800 & Main & 7 & 3.18 & 3.56 & 4.41 & 17 & 1.55 & 3.66 & 4.98 & 12 & 0.854 & 1.31 & 3.32 \\
\hline \multicolumn{14}{|c|}{ Phosphorus in unfiltered water (mg/L as phosphorus) } \\
\hline 07103700 & Main & 13 & $<0.02$ & 0.02 & 0.04 & 23 & 0.011 & 0.030 & 0.563 & 21 & 0.02 & 1.96 & 71.3 \\
\hline 07103707 & Main & 31 & $<0.02$ & 0.023 & 0.228 & 56 & 0.008 & 0.052 & 65.5 & -- & -- & -- & -- \\
\hline 385854104470100 & Trib & -- & -- & -- & -- & 5 & E0.02 & 0.070 & 0.260 & 1 & 1.09 & 1.09 & 1.09 \\
\hline 07103960 & Trib & 2 & $<0.02$ & 0.027 & 0.037 & 18 & 0.010 & 0.049 & 4.76 & 1 & 0.69 & 0.69 & 0.69 \\
\hline 385750104475001 & Trib & -- & -- & -- & -- & 6 & 0.04 & 0.07 & 0.74 & -- & -- & -- & -- \\
\hline 07103970 & Main & 11 & 0.430 & 0.484 & 0.850 & 23 & 0.180 & 0.404 & 0.64 & 21 & 0.21 & 0.870 & 2.83 \\
\hline 07103977 & Trib & -- & -- & -- & -- & 4 & E0.04 & 0.075 & 0.15 & 2 & 0.34 & 0.545 & 0.750 \\
\hline 07103985 & Trib & -- & -- & -- & -- & 6 & E0.04 & 0.050 & 2.08 & -- & -- & -- & -- \\
\hline 07103990 & Trib & 4 & $<0.02$ & 0.041 & 0.173 & 16 & 0.006 & 0.030 & 0.20 & 6 & 0.42 & 3.44 & 8.45 \\
\hline 07104050 & Trib & -- & -- & -- & -- & 4 & E0.02 & 0.025 & 0.05 & 2 & 0.29 & 0.545 & 0.800 \\
\hline 385501104483701 & Trib & -- & -- & -- & -- & 2 & $<0.04$ & $<0.04$ & E0.04 & -- & -- & -- & -- \\
\hline 385204104510101 & Trib & -- & -- & -- & -- & 4 & $<0.04$ & $<0.04$ & $<0.04$ & 1 & 0.11 & 0.11 & 0.11 \\
\hline 385124104501301 & Trib & 3 & $<0.02$ & 0.007 & 0.021 & 18 & 0.007 & 0.036 & 0.937 & 3 & 0.31 & 0.46 & 0.73 \\
\hline 07104905 & Main & 24 & 0.241 & 0.469 & 1.48 & 33 & 0.240 & 0.450 & 1.43 & 16 & 0.23 & 1.77 & 7.62 \\
\hline 07105000 & Trib & -- & -- & -- & -- & 6 & $<0.04$ & $<0.04$ & 0.16 & -- & -- & -- & - \\
\hline 384909104504401 & Trib & 2 & 0.009 & 0.010 & 0.010 & 19 & $<0.02$ & $<0.04$ & 3.48 & -- & -- & -- & -- \\
\hline 07105500 & Main & 27 & 0.130 & 0.300 & 1.330 & 32 & 0.130 & 0.299 & 1.18 & 15 & 0.150 & 1.89 & 13.3 \\
\hline 07105530 & Main & 25 & 0.221 & 0.612 & 2.44 & 33 & 0.189 & 0.363 & 1.720 & 20 & 0.460 & 2.11 & 7.70 \\
\hline 07105600 & Trib & 3 & 0.032 & 0.135 & 0.142 & 12 & 0.026 & 0.085 & 2.54 & 4 & 0.991 & 2.53 & 6.46 \\
\hline 07105800 & Main & 25 & 0.306 & 0.730 & 1.70 & 34 & 0.356 & 0.722 & 2.18 & 13 & 0.730 & 2.37 & 5.73 \\
\hline
\end{tabular}




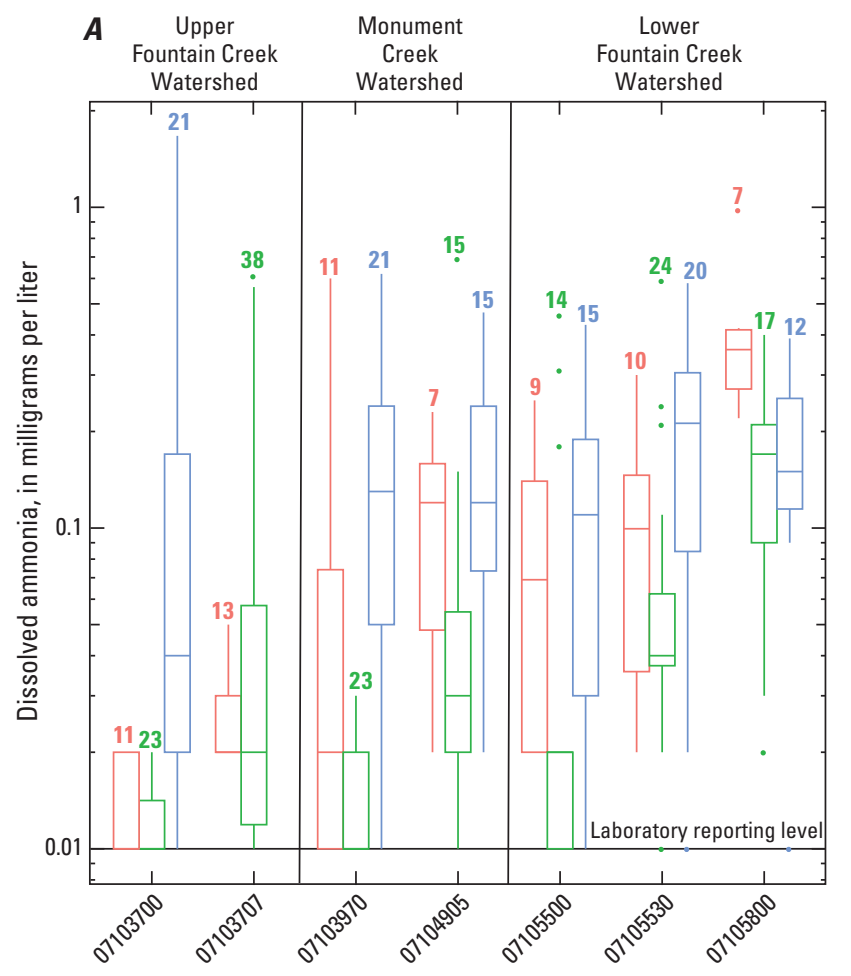

Site number

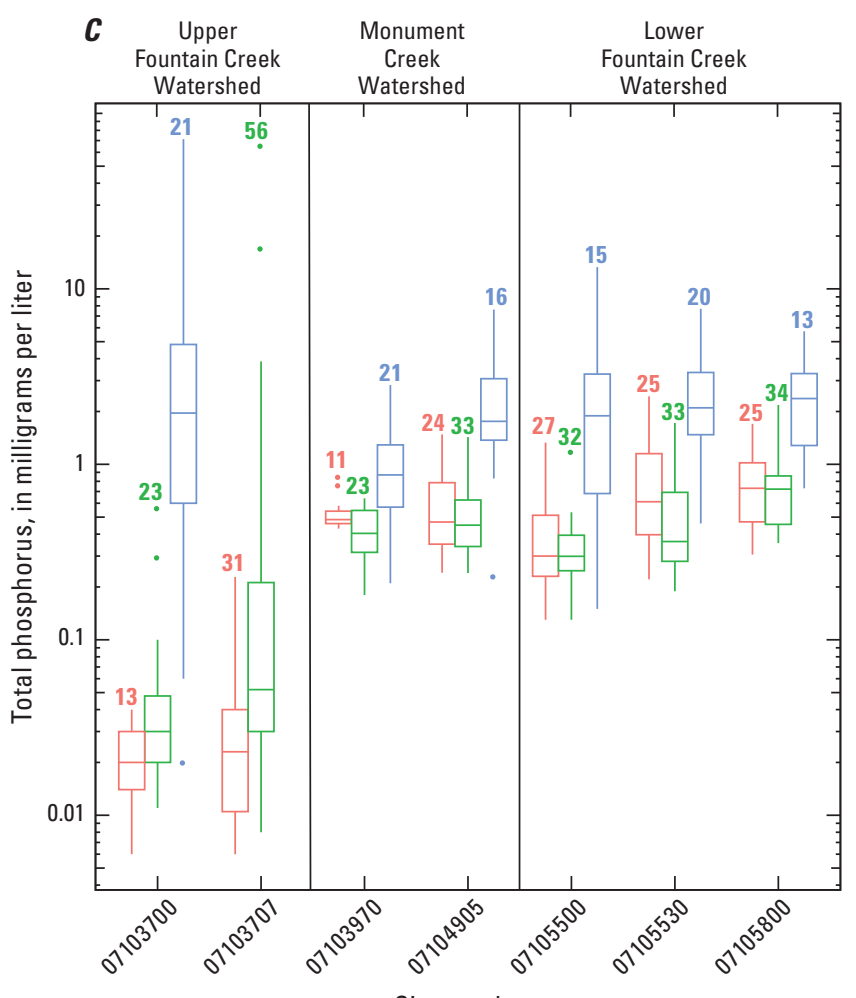

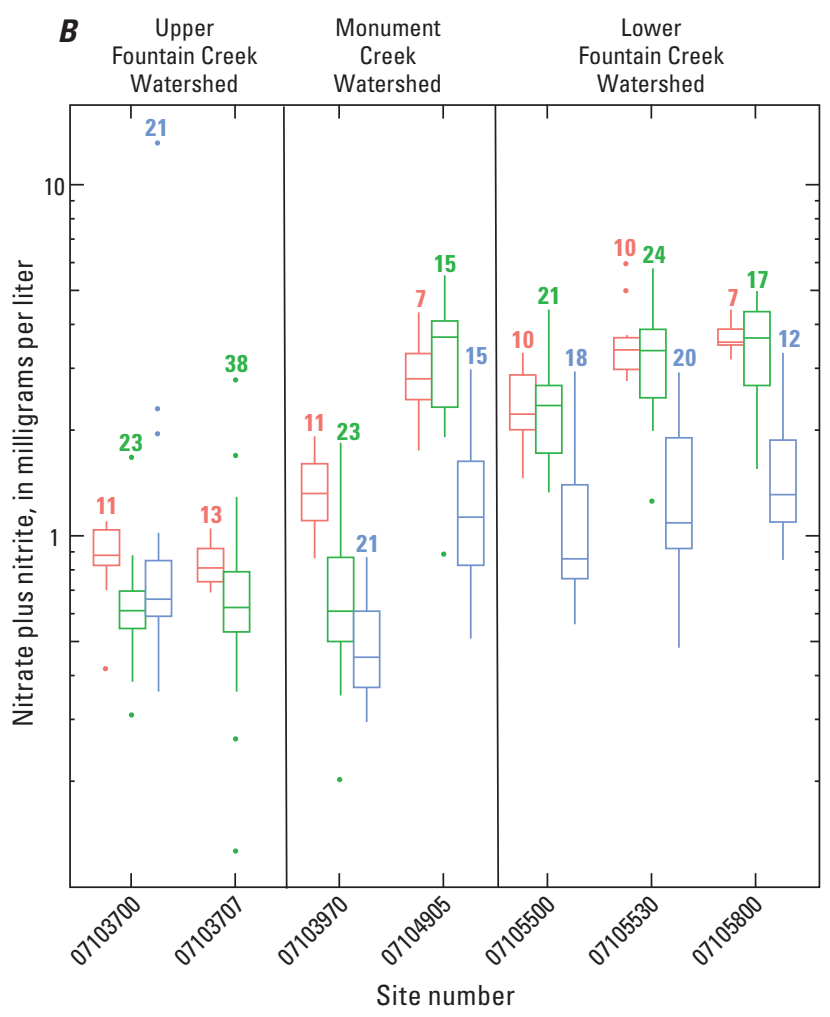

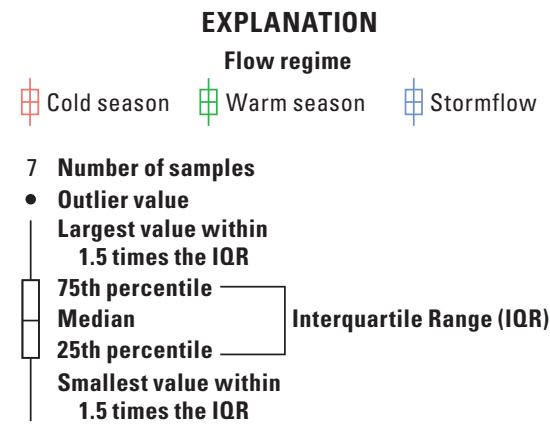

Site number

Figure 7. Variations in $A$, dissolved ammonia, $B$, nitrate plus nitrite, and $C$, total phosphorus concentrations at sites for coldseason flow, warm-season flow, and stormflow in the Fountain and Monument Creek watersheds, Colorado, 2007 through 2015. 

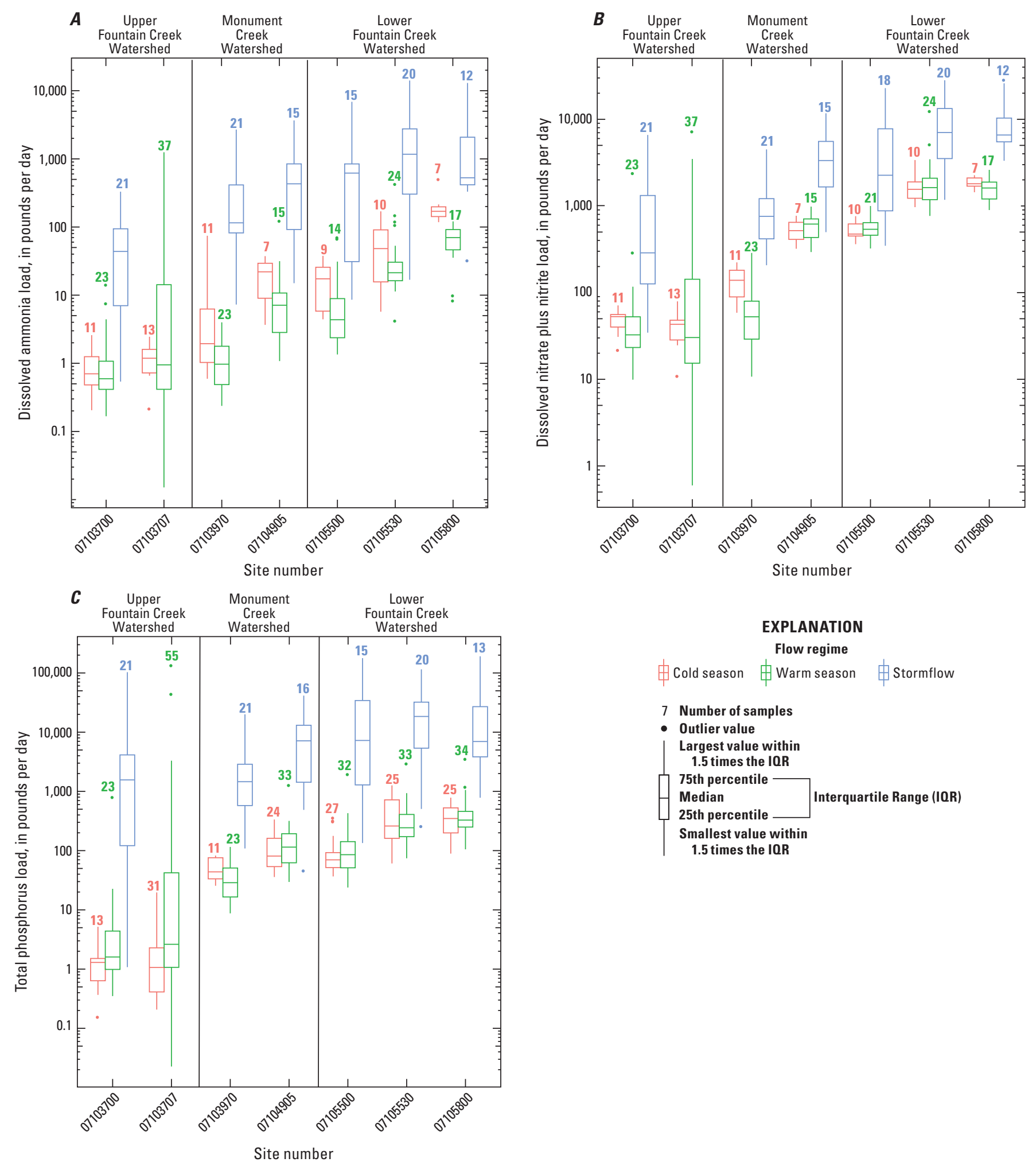

Figure 8. Variations in $A$, dissolved ammonia, $B$, dissolved nitrate plus nitrite, and $C$, total phosphorus loads at sites for coldseason flow, warm-season flow, and stormflow in the Fountain and Monument Creek watersheds, Colorado, 2007 through 2015. 
cold-season and warm-season flows in Upper Fountain Creek between sites 07103700 (FoCr_Manitou) and 07103707 (FoCr_8th) (figs. 9 and 10, table 8). Of these trace elements, manganese, selenium, and zinc concentrations increased the most between the two sites and the largest increases occurred during cold-season flow when streamflow is predominantly from groundwater sources (table 8). These large increases in trace element concentrations, particularly during cold-season flows, between sites 07103700 and 07103707 are likely because of input from the Gold Hill Mesa area. It is possible that large increases in concentrations of some or all of these trace elements also occurred during stormflows between these two sites, but stormflow samples were not collected at the downstream site 07103707 (FoCr_8th).

The water-quality standard for total arsenic of $50 \mu \mathrm{g} / \mathrm{L}$ was exceeded in three samples collected during warm-season flows at site 07103707 (FoCr_8th), and in three samples collected during stormflows at site 07103700 (FoCr_Manitou), but not in cold-season flows. As with maximum nutrient concentrations, the maximum concentrations of dissolved and total arsenic, dissolved boron, total lead, total manganese, total nickel, dissolved and total selenium, and total zinc concentrations were measured in a single stormflow sample collected on July 1, 2013, after the Waldo Canyon fire.

\section{Trace-Element Loads}

Trace-element loads during cold-season flow and warmseason flow generally were small in Upper Fountain Creek at sites 07103700 (FoCr_Manitou) and 07103707 (FoCr_8th) (figs. 11 and 12). Median cold-season flow and warm-season flow loads of dissolved boron, copper, and selenium were less than $5 \mathrm{lb} / \mathrm{d}$ compared to stormflow loads that ranged from 4 to 24 times larger. The differences in loads are largely because of the proportional streamflow increase during periods of stormflow. Median cold-season and warm-season loads of total arsenic, copper, lead, nickel, and selenium were less than $1 \mathrm{lb} / \mathrm{d}$ at sites 07103700 (FoCr_Manitou) and 07103707 (FoCr_8th), whereas, stormflow loads for these constituents were 300 to more than 3,000 times larger than cold-season and warm-season loads. Median stormflow loads at site 07103700 (FoCr_Manitou) for total manganese and total zinc were 1,842 and $187 \mathrm{lb} / \mathrm{d}$, respectively, and were 720 to 880 times larger during stormflow than during cold-season flow and warmseason flow.

\section{Suspended Sediment}

Suspended-sediment concentrations ranged from 2 to $155,000 \mathrm{mg} / \mathrm{L}$ in samples collected at site 07103700 (FoCr_Manitou) and from 1 to $51,300 \mathrm{mg} / \mathrm{L}$ at site 07103707 (FoCr_8th). Median suspended-sediment concentrations increased in the downstream direction from 9 to $26 \mathrm{mg} / \mathrm{L}$ in cold-season flows and from 17 to $24 \mathrm{mg} / \mathrm{L}$ in warm-season flows between the main-stem sites, however, these increases were not statistically significant (tables 5 and 9). The highest suspended-sediment concentrations were measured in stormflow samples collected after the Waldo Canyon fire, with the maximum concentration of $155,000 \mathrm{mg} / \mathrm{L}$ being measured in the first stormflow sample collected at site 07103700 (FoCr_Manitou) after the Waldo Canyon fire on July 1, 2013. As previously discussed, the maximum concentrations of dissolved ammonia, nitrate plus nitrite, total phosphorus, dissolved and total arsenic, dissolved boron, total lead, total manganese, total nickel, dissolved and total selenium, and total zinc were also measured in this same sample.

\section{Suspended-Sediment Discharge and Yield}

During warm-season flow and cold-season flow, median suspended-sediment discharge and median suspendedsediment yield increased in the downstream direction between the main-stem sites on Upper Fountain Creek; however, these increases were not statistically significant (tables 10 and 11). At site 07103700 (FoCr_Manitou), median suspendedsediment discharge ranged from 0.26 tons per day (tons/d) during cold-season flow to 1,130 tons/d during stormflow (table 10). The median suspended-sediment yield at site 07103700 (FoCr_Manitou) was more than 3,600 times larger during stormflow than during warm-season flow. At downstream site 07103707 (FoCr_8th), the median suspendedsediment discharge during cold-season flow was 0.76 tons/d (table 10) and the median suspended-sediment yield was 0.006 tons $/ \mathrm{d} / \mathrm{mi}^{2}$ (table 11). No stormflow samples were collected at this site; therefore, downstream changes during stormflow could not be evaluated.

\section{Monument Creek Watershed}

Water-quality samples were collected during coldseason flows, warm-season flows, and stormflows at mainstem sites 07103970 (MoCr_Woodmen) and 07104905 (MoCr_Bijou) and during warm-season flows and stormflows at seven tributary sites from 2007 through 2015. In 2015, additional samples for $E$. coli bacteria were collected quarterly during dry weather conditions (described in the Methods of Investigation section of this report) at 21 sites in the Monument Creek watershed (table 1). Based on the median instantaneous discharge values at each site (table 4), Monument Creek gained about $16.5 \mathrm{ft}^{3} / \mathrm{s}$ of streamflow during cold-season flows and $21.0 \mathrm{ft}^{3} / \mathrm{s}$ during warm-season flows between sites 07103970 (MoCr_Woodmen) and 07104905 (MoCr_Bijou). Much of this increase in streamflow can be attributed to the many tributaries that drain into Monument Creek between the two sites. At the measured tributary sites, median warm-season flows ranged from less than 1.0 to $4.8 \mathrm{ft}^{3} / \mathrm{s}$ while median stormflows ranged from 2.5 to $198 \mathrm{ft}^{3} / \mathrm{s}$ (table 4, fig. 4). In addition, the J.D. Phillips Water Resource Recovery Facility discharges treated water to the stream between the two sites. The following sections of the report discuss water-quality constituent values and loads in the Monument Creek watershed. 


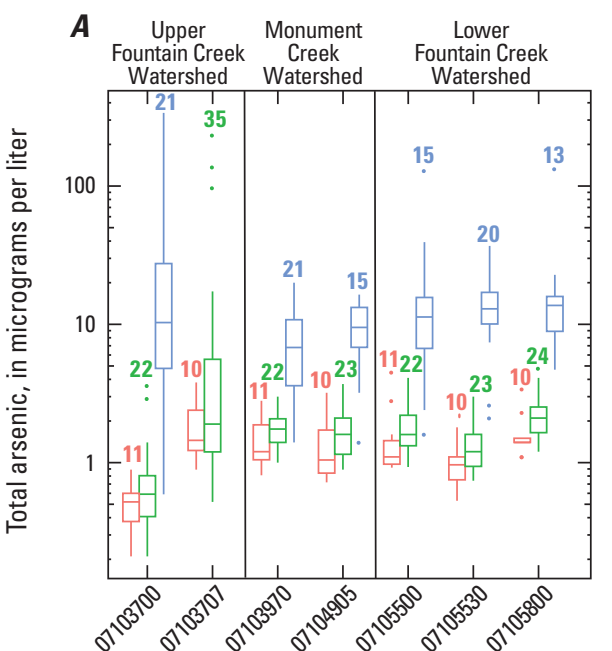

Site number

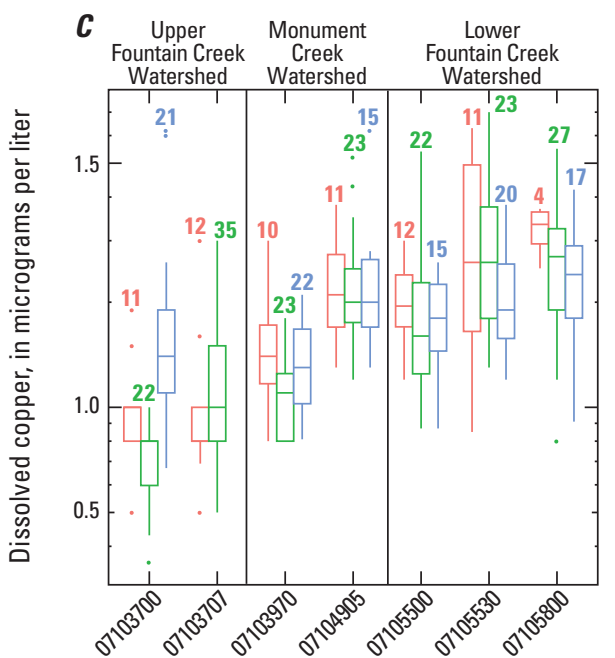

Site number

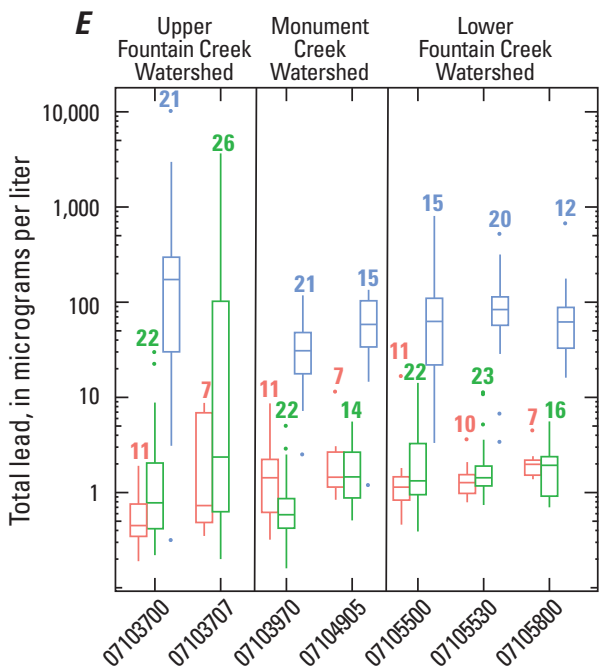

Site number

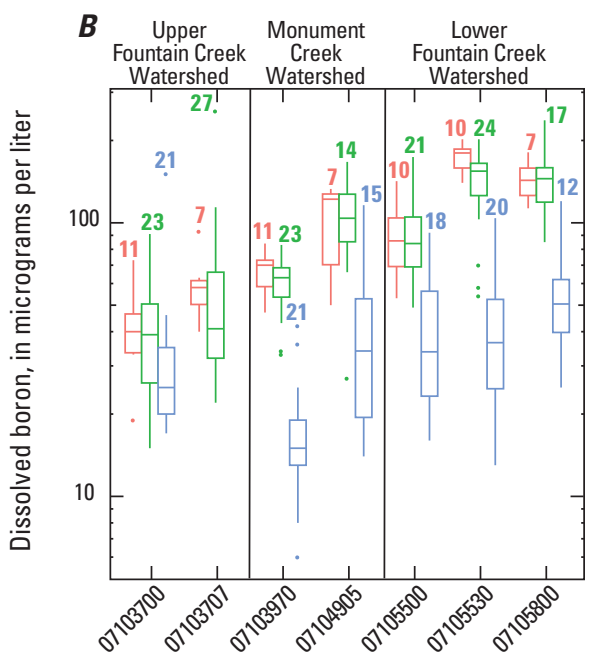

Site number

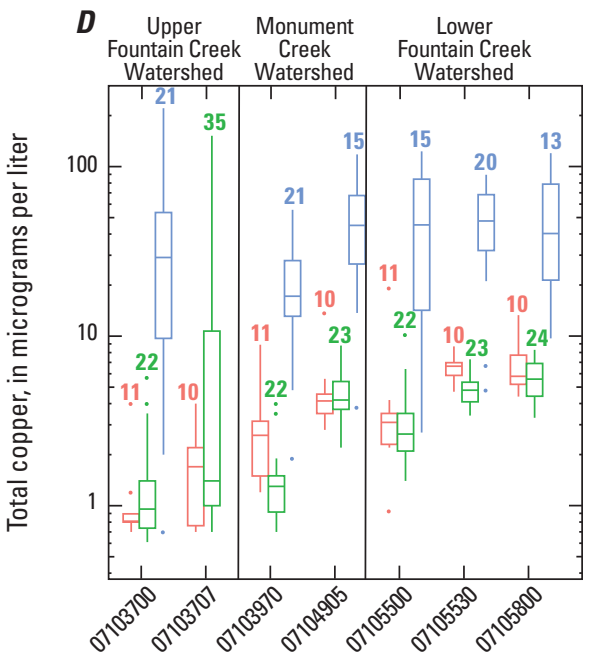

Site number

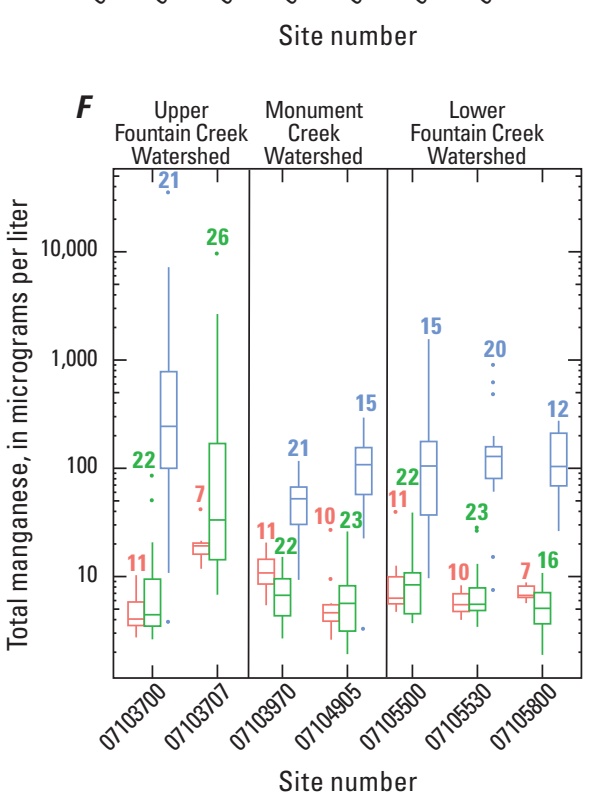

Site number

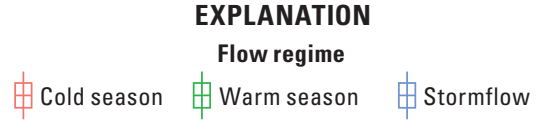

27 Number of samples

- Outlier value

Largest value within 1.5 times the IOR 75th percentile

Median

25th percentile

Smallest value within

1.5 times the IOR

Figure 9. Variations in $A$, total arsenic, $B$, dissolved boron, $C$, dissolved copper, $D$, total copper, $E$, total lead, and $F$, total manganese concentrations at sites for cold-season flow, warm-season flow, and stormflow in the Fountain and Monument Creek watersheds, Colorado, 2007 through 2015. 

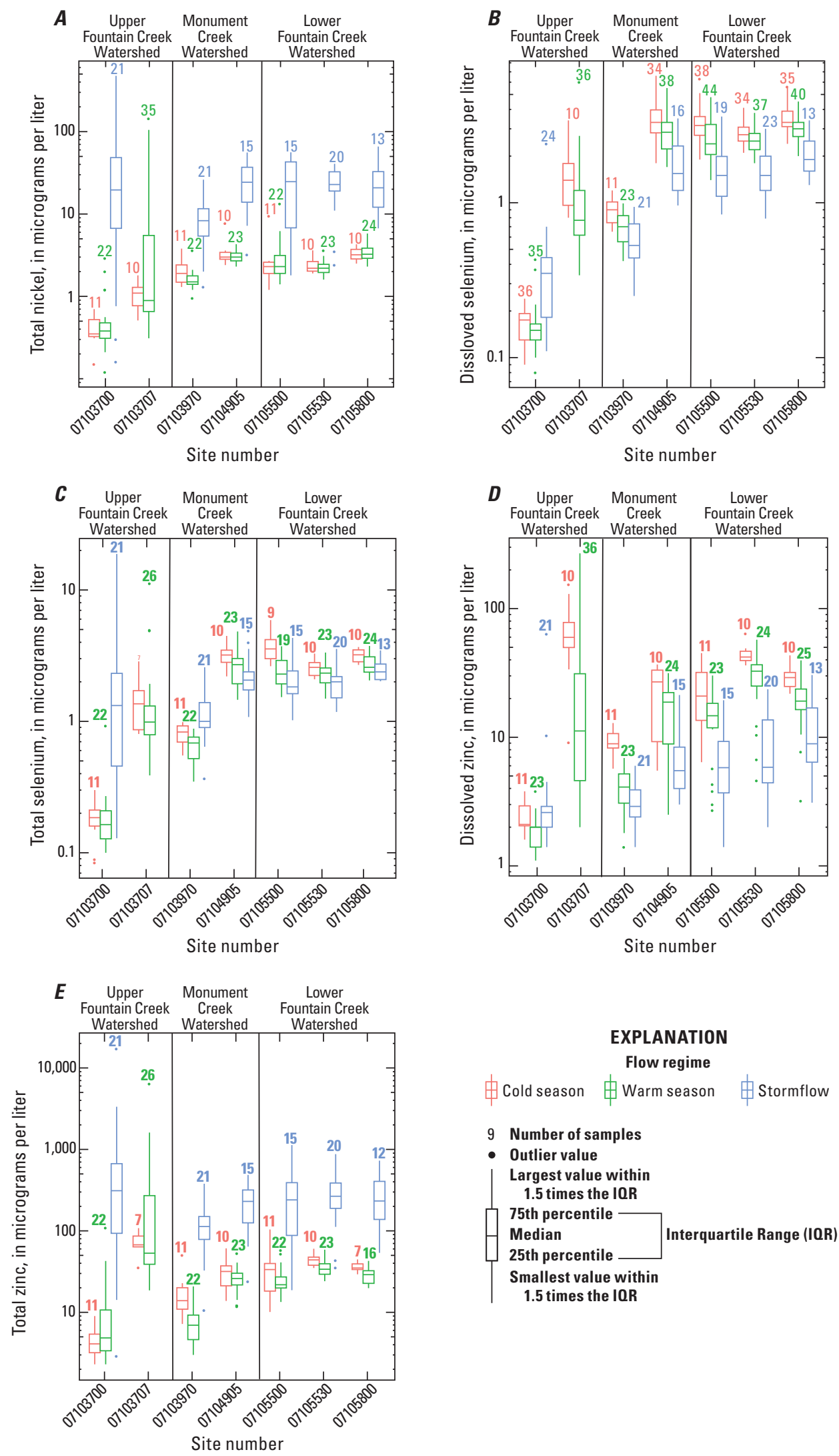

Figure 10. Variations in $A$, total nickel, $B$, dissolved selenium, $C$, total selenium, $D$, dissolved zinc, and $E$, total zinc concentrations at sites for cold-season flow, warm-season flow, and stormflow in the Fountain and Monument Creek watersheds, Colorado, 2007 through 2015. 
Table 8. Minimum, median, and maximum concentrations for selected trace elements at sites in the Fountain Creek watershed, Colorado, 2007-2015.

[USGS, U.S. Geological Survey; Main, main-stem site; Trib, tributary site; $\mu \mathrm{g} / \mathrm{L}$, micrograms per liter; N, number of samples; E, estimated value; <, less than the value shown; --, no value]

\begin{tabular}{|c|c|c|c|c|c|c|c|c|c|c|c|c|c|}
\hline \multirow{2}{*}{$\begin{array}{c}\text { USGS } \\
\text { site number }\end{array}$} & \multirow{2}{*}{$\begin{array}{l}\text { Site } \\
\text { type }\end{array}$} & \multicolumn{4}{|c|}{ Cold-season flow } & \multicolumn{4}{|c|}{ Warm-season flow } & \multicolumn{4}{|c|}{ Stormflow } \\
\hline & & $\mathbf{N}$ & Minimum & Median & Maximum & $\mathbf{N}$ & Minimum & Median & Maximum & $\mathbf{N}$ & Minimum & Median & Maximum \\
\hline \multicolumn{14}{|c|}{ Arsenic in unfiltered water $(\mu \mathrm{g} / \mathrm{L})$} \\
\hline 07103700 & Main & 11 & 0.210 & 0.520 & 0.890 & 22 & 0.210 & 0.595 & 3.60 & 21 & 0.590 & 10.3 & 338 \\
\hline 07103707 & Main & 10 & 0.890 & 1.45 & 3.80 & 35 & 0.520 & 1.90 & 223 & -- & -- & -- & -- \\
\hline 07103960 & Trib & -- & -- & -- & -- & -- & -- & -- & -- & -- & -- & -- & -- \\
\hline 07103970 & Main & 11 & 0.810 & 1.20 & 2.80 & 22 & 1.00 & 1.75 & 3.00 & 21 & 1.40 & 6.80 & 20.0 \\
\hline 07103990 & Trib & -- & -- & -- & -- & -- & -- & -- & -- & -- & -- & -- & -- \\
\hline 385124104501301 & Trib & -- & -- & -- & -- & -- & -- & -- & -- & -- & -- & -- & -- \\
\hline 07104905 & Main & 10 & 0.720 & 1.06 & 3.20 & 23 & 0.890 & 1.60 & 3.70 & 15 & 1.40 & 9.50 & 16.4 \\
\hline 384909104504401 & Trib & -- & -- & -- & -- & -- & -- & -- & -- & -- & -- & -- & -- \\
\hline 07105500 & Main & 11 & 0.920 & 1.10 & 4.50 & 22 & 0.930 & 1.60 & 4.10 & 15 & 1.60 & 11.3 & 129 \\
\hline 07105530 & Main & 10 & 0.530 & 0.965 & 1.80 & 23 & 0.740 & 1.20 & 3.00 & 20 & 2.10 & 13.0 & 36.9 \\
\hline 07105600 & Trib & -- & -- & -- & -- & 3 & 2.80 & 4.00 & 4.40 & 4 & 7.60 & 9.15 & 14.6 \\
\hline 07105800 & Main & 10 & 1.10 & 1.40 & 3.40 & 24 & 1.20 & 2.10 & 4.80 & 13 & 4.70 & 13.7 & 133 \\
\hline \multicolumn{14}{|c|}{ Arsenic in filtered water $(\mu \mathrm{g} / \mathrm{L})$} \\
\hline 07103700 & Main & -- & -- & -- & -- & -- & -- & -- & -- & 3 & 0.730 & 2.70 & 10.3 \\
\hline 07103707 & Main & 3 & 0.560 & 0.610 & 1.10 & 12 & 0.290 & 0.810 & 6.40 & -- & -- & -- & -- \\
\hline 07103960 & Trib & -- & -- & -- & -- & -- & -- & -- & -- & -- & -- & -- & -- \\
\hline 07103970 & Main & -- & -- & -- & -- & -- & -- & -- & -- & 4 & 0.550 & 0.630 & 1.00 \\
\hline 07103990 & Trib & -- & -- & -- & -- & -- & -- & -- & -- & -- & -- & -- & -- \\
\hline 385124104501301 & Trib & -- & -- & -- & -- & -- & -- & -- & -- & -- & -- & -- & -- \\
\hline 07104905 & Main & 3 & 0.470 & 0.600 & 0.670 & 9 & 0.600 & 0.830 & 1.70 & 1 & 0.610 & 0.610 & 0.610 \\
\hline 384909104504401 & Trib & -- & -- & -- & -- & -- & -- & -- & -- & -- & -- & -- & -- \\
\hline 07105500 & Main & 3 & 0.630 & 0.660 & 0.850 & 9 & 0.520 & 0.960 & 1.70 & 1 & 2.50 & 2.50 & 2.50 \\
\hline 07105530 & Main & 3 & 0.390 & 0.540 & 0.580 & 8 & 0.520 & 0.650 & 1.50 & 3 & 0.840 & 1.40 & 1.70 \\
\hline 07105600 & Trib & -- & -- & -- & -- & -- & -- & -- & -- & -- & -- & -- & -- \\
\hline 07105800 & Main & 3 & 0.730 & 0.920 & 0.930 & 8 & 0.630 & 0.840 & 2.00 & 1 & 0.940 & 0.940 & 0.940 \\
\hline \multicolumn{14}{|c|}{ Boron in filtered water $(\mu \mathrm{g} / \mathrm{L})$} \\
\hline 07103700 & Main & 11 & 19 & 40 & 73 & 23 & 15 & 39 & 91 & 21 & 17 & 25 & 151 \\
\hline 07103707 & Main & 7 & 40 & 58 & 93 & 27 & 22 & 41 & 256 & -- & -- & -- & -- \\
\hline 07103960 & Trib & -- & -- & -- & -- & -- & -- & -- & -- & -- & -- & -- & -- \\
\hline 07103970 & Main & 11 & 47 & 70 & 84 & 23 & 33 & 63 & 83 & 21 & 6 & 15 & 42 \\
\hline 07103990 & Trib & -- & -- & -- & -- & -- & -- & -- & -- & -- & -- & -- & -- \\
\hline 07104050 & Trib & -- & -- & -- & -- & -- & -- & -- & -- & -- & -- & -- & -- \\
\hline 385124104501301 & Trib & -- & -- & -- & -- & -- & -- & -- & -- & -- & -- & -- & -- \\
\hline 07104905 & Main & 7 & 50 & 122 & 133 & 14 & 27 & 104 & 167 & 15 & 14 & 34 & 116 \\
\hline 384909104504401 & Trib & -- & -- & -- & -- & -- & -- & -- & -- & -- & -- & -- & -- \\
\hline 07105500 & Main & 10 & 53 & 86 & 142 & 21 & 49 & 84 & 174 & 18 & 16 & 34 & 92 \\
\hline 07105530 & Main & 10 & 140 & 180 & 202 & 24 & 54 & 155 & 202 & 20 & 13 & 37 & 104 \\
\hline 07105600 & Trib & -- & -- & -- & -- & -- & -- & -- & -- & -- & -- & -- & -- \\
\hline 07105800 & Main & 7 & 113 & 143 & 181 & 17 & 85 & 145 & 237 & 12 & 25 & 51 & 120 \\
\hline
\end{tabular}


Table 8. Minimum, median, and maximum concentrations for selected trace elements at sites in the Fountain Creek watershed, Colorado, 2007-2015.-Continued

[USGS, U.S. Geological Survey; Main, main-stem site; Trib, tributary site; $\mu \mathrm{g} / \mathrm{L}$, micrograms per liter; N, number of samples; E, estimated value; <, less than the value shown; --, no value]

\begin{tabular}{|c|c|c|c|c|c|c|c|c|c|c|c|c|c|}
\hline \multirow{2}{*}{$\begin{array}{c}\text { USGS } \\
\text { site number }\end{array}$} & \multirow{2}{*}{$\begin{array}{l}\text { Site } \\
\text { type }\end{array}$} & \multicolumn{4}{|c|}{ Cold-season flow } & \multicolumn{4}{|c|}{ Warm-season flow } & \multicolumn{4}{|c|}{ Stormflow } \\
\hline & & $\mathbf{N}$ & Minimum & Median & Maximum & $\mathbf{N}$ & Minimum & Median & Maximum & $\mathbf{N}$ & Minimum & Median & Maximum \\
\hline \multicolumn{14}{|c|}{ Copper in unfiltered water $(\mu \mathrm{g} / \mathrm{L})$} \\
\hline 07103700 & Main & 11 & 0.700 & 0.810 & 4.00 & 22 & 0.610 & 0.955 & 5.70 & 21 & 0.700 & 29.1 & 221 \\
\hline 07103707 & Main & 10 & 0.700 & 1.70 & 4.00 & 35 & 0.700 & 1.40 & 152 & -- & -- & -- & -- \\
\hline 07103960 & Trib & -- & -- & -- & -- & -- & -- & -- & -- & -- & -- & -- & -- \\
\hline 07103970 & Main & 11 & 1.20 & 2.60 & 8.90 & 22 & 0.700 & 1.30 & 4.00 & 21 & 1.90 & 17.2 & 55.6 \\
\hline 07103990 & Trib & -- & -- & -- & -- & -- & -- & -- & -- & -- & -- & -- & -- \\
\hline 385124104501301 & Trib & -- & -- & -- & -- & -- & -- & -- & -- & -- & -- & -- & -- \\
\hline 07104905 & Main & 10 & 2.80 & 4.15 & 13.7 & 23 & 2.20 & 4.20 & 8.80 & 15 & 3.80 & 45.0 & 118 \\
\hline 384909104504401 & Trib & -- & -- & -- & -- & -- & -- & -- & -- & -- & -- & -- & -- \\
\hline 07105500 & Main & 11 & 0.930 & 3.10 & 19.2 & 22 & 1.40 & 2.65 & 10.2 & 15 & 2.70 & 45.3 & 123 \\
\hline 07105530 & Main & 10 & 4.70 & 6.65 & 8.70 & 23 & 3.40 & 4.80 & 7.30 & 20 & 4.80 & 48.0 & 89.5 \\
\hline 07105600 & Trib & -- & -- & -- & -- & 3 & 2.90 & 7.50 & 13.1 & 4 & 40.4 & 58.9 & 65.7 \\
\hline 07105800 & Main & 10 & 4.40 & 5.80 & 13.3 & 24 & 3.30 & 5.60 & 8.30 & 13 & 9.70 & 40.3 & 120 \\
\hline \multicolumn{14}{|c|}{ Copper in filtered water $(\mu \mathrm{g} / \mathrm{L})$} \\
\hline 07103700 & Main & 11 & 0.500 & 1.00 & 1.90 & 23 & 0.360 & 0.800 & 1.00 & 21 & 0.670 & 1.40 & 6.20 \\
\hline 07103707 & Main & 10 & 0.500 & 0.900 & 3.00 & 36 & 0.500 & 0.900 & 3.000 & -- & -- & -- & -- \\
\hline 07103960 & Trib & -- & -- & -- & -- & -- & -- & -- & -- & -- & -- & -- & -- \\
\hline 07103970 & Main & 11 & 0.900 & 1.40 & 3.00 & 23 & 0.800 & 0.900 & 1.80 & 21 & 0.800 & 1.30 & 2.10 \\
\hline 07103990 & Trib & -- & -- & -- & -- & -- & -- & -- & -- & -- & -- & -- & -- \\
\hline 385124104501301 & Trib & -- & -- & -- & -- & -- & -- & -- & -- & -- & -- & -- & -- \\
\hline 07104905 & Main & 10 & 1.50 & 2.40 & 3.50 & 24 & 1.20 & 2.10 & 5.20 & 15 & 1.30 & 1.90 & 6.20 \\
\hline 384909104504401 & Trib & -- & -- & -- & -- & -- & -- & -- & -- & -- & -- & -- & -- \\
\hline 07105500 & Main & 11 & 1.20 & 2.00 & 3.00 & 23 & 0.870 & 1.60 & 5.40 & 15 & 0.870 & 1.80 & 3.00 \\
\hline 07105530 & Main & 10 & 2.20 & 3.70 & 6.30 & 24 & 0.850 & 2.60 & 7.00 & 20 & 1.20 & 1.60 & 4.00 \\
\hline 07105600 & Trib & -- & -- & -- & -- & -- & -- & -- & -- & -- & -- & -- & -- \\
\hline 07105800 & Main & 10 & 2.20 & 3.00 & 3.70 & 25 & 0.800 & 2.70 & 5.50 & 13 & 0.910 & 1.70 & 4.20 \\
\hline \multicolumn{14}{|c|}{ Lead in unfiltered water $(\mu \mathrm{g} / \mathrm{L})$} \\
\hline 07103700 & Main & 11 & 0.190 & 0.450 & 1.91 & 22 & 0.220 & 0.780 & 30.2 & 21 & 0.320 & 173 & 10300 \\
\hline 07103707 & Main & 7 & 0.350 & 0.730 & 8.74 & 26 & 0.200 & 2.39 & 3660 & -- & -- & -- & -- \\
\hline 07103960 & Trib & -- & -- & -- & -- & -- & -- & -- & -- & -- & -- & -- & -- \\
\hline 07103970 & Main & 11 & 0.320 & 1.43 & 8.65 & 22 & 0.160 & 0.590 & 5.07 & 21 & 2.54 & 30.9 & 118 \\
\hline 07103990 & Trib & -- & -- & -- & -- & -- & -- & -- & -- & -- & -- & -- & -- \\
\hline 385124104501301 & Trib & -- & -- & -- & -- & -- & -- & -- & -- & -- & -- & -- & -- \\
\hline 07104905 & Main & 7 & 0.840 & 1.45 & 11.6 & 14 & 0.510 & 1.47 & 5.57 & 15 & 1.21 & 58.4 & 135 \\
\hline 384909104504401 & Trib & -- & -- & -- & -- & -- & -- & -- & -- & -- & -- & -- & -- \\
\hline 07105500 & Main & 11 & 0.460 & 1.14 & 16.9 & 22 & 0.39 & 1.33 & 14.2 & 15 & 3.32 & 62.8 & 806 \\
\hline 07105530 & Main & 10 & 0.790 & 1.28 & 3.66 & 23 & 0.74 & 1.43 & 11.4 & 20 & 3.44 & 83.7 & 527 \\
\hline 07105600 & Trib & -- & -- & -- & -- & 3 & 1.21 & 4.07 & 7.05 & 4 & 34.2 & 62.3 & 130 \\
\hline 07105800 & Main & 7 & 1.38 & 1.98 & 4.54 & 16 & 0.70 & 1.94 & 5.59 & 12 & 16.1 & 62.0 & 680 \\
\hline
\end{tabular}


Table 8. Minimum, median, and maximum concentrations for selected trace elements at sites in the Fountain Creek watershed, Colorado, 2007-2015.-Continued

[USGS, U.S. Geological Survey; Main, main-stem site; Trib, tributary site; $\mu \mathrm{g} / \mathrm{L}$, micrograms per liter; N, number of samples; E, estimated value; <, less than the value shown; --, no value]

\begin{tabular}{|c|c|c|c|c|c|c|c|c|c|c|c|c|c|}
\hline \multirow{2}{*}{$\begin{array}{c}\text { USGS } \\
\text { site number }\end{array}$} & \multirow{2}{*}{$\begin{array}{l}\text { Site } \\
\text { type }\end{array}$} & \multicolumn{4}{|c|}{ Cold-season flow } & \multicolumn{4}{|c|}{ Warm-season flow } & \multicolumn{4}{|c|}{ Stormflow } \\
\hline & & $\mathbf{N}$ & Minimum & Median & Maximum & $\mathbf{N}$ & Minimum & Median & Maximum & $\mathbf{N}$ & Minimum & Median & Maximum \\
\hline \multicolumn{14}{|c|}{ Manganese in unfiltered water $(\mu \mathrm{g} / \mathrm{L})$} \\
\hline 07103700 & Main & 11 & 27.4 & 40.5 & 103 & 22 & 26.3 & 44.4 & 863 & 21 & 38.5 & 2,440 & 357,000 \\
\hline 07103707 & Main & 7 & 118 & 192 & 422 & 26 & 67.9 & 334 & 97200 & -- & -- & -- & -- \\
\hline 07103960 & Trib & -- & -- & -- & -- & -- & -- & -- & -- & -- & -- & -- & -- \\
\hline 07103970 & Main & 11 & 54.3 & 108 & 206 & 22 & 26.8 & 67.1 & 152 & 21 & 93.2 & 523 & 1,170 \\
\hline 07103990 & Trib & -- & -- & -- & -- & -- & -- & -- & -- & -- & -- & -- & -- \\
\hline 385124104501301 & Trib & -- & -- & -- & -- & -- & -- & -- & -- & -- & -- & -- & -- \\
\hline 07104905 & Main & 10 & 26.1 & 46.3 & 272 & 23 & 19.2 & 56.5 & 261 & 15 & 33.2 & 1,080 & 2,940 \\
\hline 384909104504401 & Trib & -- & -- & -- & -- & -- & -- & -- & -- & -- & -- & -- & -- \\
\hline 07105500 & Main & 11 & 47.2 & 63.1 & 399 & 22 & 37.1 & 84.3 & 390 & 15 & 96.5 & 1,050 & 15,600 \\
\hline 07105530 & Main & 10 & 39.8 & 55.0 & 83.0 & 23 & 34.3 & 55.0 & 286 & 20 & 75.8 & 1,290 & 9,100 \\
\hline 07105600 & Trib & -- & -- & -- & -- & 3 & 106 & 161 & 313 & 4 & 629 & 1,083 & 2,790 \\
\hline 07105800 & Main & 7 & 56.8 & 67.0 & 99.3 & 16 & 18.9 & 51.1 & 108 & 12 & 263 & 1,059 & 2,750 \\
\hline \multicolumn{14}{|c|}{ Manganese in filtered water $(\mu \mathrm{g} / \mathrm{L})$} \\
\hline 07103700 & Main & 11 & 15.7 & 26.8 & 62.3 & 23 & 8.56 & 21.3 & 82.1 & 21 & 2.92 & 13.4 & 1,020 \\
\hline 07103707 & Main & 10 & 104 & 176 & 806 & 36 & 8.58 & 104 & 944 & -- & -- & -- & -- \\
\hline 07103960 & Trib & -- & -- & -- & -- & -- & -- & -- & -- & -- & -- & -- & -- \\
\hline 07103970 & Main & 11 & 28.3 & 54.6 & 124 & 23 & 5.70 & 29.1 & 98.1 & 21 & 11.9 & 29.8 & 43.4 \\
\hline 07103990 & Trib & -- & -- & -- & -- & -- & -- & -- & -- & -- & -- & -- & -- \\
\hline 385124104501301 & Trib & -- & -- & -- & -- & -- & -- & -- & -- & -- & -- & -- & -- \\
\hline 07104905 & Main & 10 & 2.10 & 14.7 & 38.1 & 24 & 2.01 & 8.47 & 120 & 15 & 0.610 & 6.75 & 67.0 \\
\hline 384909104504401 & Trib & -- & -- & -- & -- & - & -- & -- & -- & -- & -- & -- & -- \\
\hline 07105500 & Main & 11 & 17.6 & 40.5 & 97.3 & 23 & 5.50 & 24.2 & 95.0 & 15 & 0.710 & 11.9 & 83.8 \\
\hline 07105530 & Main & 10 & 30.4 & 42.9 & 75.9 & 24 & 6.01 & 30.5 & 157 & 20 & 4.69 & 16.9 & 297 \\
\hline 07105600 & Trib & -- & -- & -- & -- & -- & -- & -- & -- & -- & -- & -- & -- \\
\hline 07105800 & Main & 10 & 5.92 & 30.0 & 63.4 & 25 & 2.80 & 5.94 & 50.8 & 13 & 2.42 & 10.2 & 66.5 \\
\hline \multicolumn{14}{|c|}{ Nickel in unfiltered water $(\mu \mathrm{g} / \mathrm{L})$} \\
\hline 07103700 & Main & 11 & 0.15 & 0.4 & 0.7 & 22 & $<0.12$ & 0.380 & 2.90 & 21 & $<0.16$ & 19.6 & 476 \\
\hline 07103707 & Main & 10 & 0.5 & 1.1 & 1.8 & 35 & 0.3 & 0.9 & 144 & -- & -- & -- & -- \\
\hline 07103960 & Trib & -- & -- & -- & -- & -- & -- & -- & -- & -- & -- & -- & -- \\
\hline 07103970 & Main & 11 & 1.3 & 1.9 & 3.8 & 22 & 1.0 & 1.5 & 3.60 & 21 & 1.3 & 8.3 & 26.1 \\
\hline 07103990 & Trib & -- & -- & -- & -- & -- & -- & -- & -- & -- & -- & -- & -- \\
\hline 385124104501301 & Trib & -- & -- & -- & -- & -- & -- & -- & -- & -- & -- & -- & -- \\
\hline 07104905 & Main & 10 & 2.4 & 3.0 & 7.0 & 23 & 2.3 & 3.0 & 4.30 & 15 & 3.2 & 24.3 & 55.8 \\
\hline 384909104504401 & Trib & -- & -- & -- & -- & -- & -- & -- & -- & -- & -- & -- & -- \\
\hline 07105500 & Main & 11 & 1.20 & 2.30 & 9.44 & 22 & 1.4 & 2.3 & 13.3 & 15 & 1.8 & 24.7 & 56.1 \\
\hline 07105530 & Main & 10 & 1.90 & 2.20 & 3.62 & 23 & 1.6 & 2.2 & 3.60 & 20 & 2.4 & 22.9 & 40.7 \\
\hline 07105600 & Trib & -- & -- & -- & -- & 3 & 4.4 & 4.6 & 7.20 & 4 & 19.2 & 24.6 & 39.5 \\
\hline 07105800 & Main & 10 & 2.50 & 3.20 & 4.29 & 24 & 2.30 & 3.25 & 5.80 & 13 & 6.7 & 20.8 & 65.9 \\
\hline
\end{tabular}


Table 8. Minimum, median, and maximum concentrations for selected trace elements at sites in the Fountain Creek watershed, Colorado, 2007-2015.-Continued

[USGS, U.S. Geological Survey; Main, main-stem site; Trib, tributary site; $\mu \mathrm{g} / \mathrm{L}$, micrograms per liter; N, number of samples; E, estimated value; <, less than the value shown; --, no value]

\begin{tabular}{|c|c|c|c|c|c|c|c|c|c|c|c|c|c|}
\hline \multirow{2}{*}{$\begin{array}{c}\text { USGS } \\
\text { site number }\end{array}$} & \multirow{2}{*}{$\begin{array}{l}\text { Site } \\
\text { type }\end{array}$} & \multicolumn{4}{|c|}{ Cold-season flow } & \multicolumn{4}{|c|}{ Warm-season flow } & \multicolumn{4}{|c|}{ Stormflow } \\
\hline & & $\mathbf{N}$ & Minimum & Median & Maximum & $\mathbf{N}$ & Minimum & Median & Maximum & $\mathbf{N}$ & Minimum & Median & Maximum \\
\hline \multicolumn{14}{|c|}{ Selenium in unfiltered water $(\mu \mathrm{g} / \mathrm{L})$} \\
\hline 07103700 & Main & 11 & 0.084 & 0.185 & 0.300 & 22 & E 0.100 & 0.164 & 0.925 & 21 & 0.129 & 1.32 & 18.8 \\
\hline 07103707 & Main & 7 & 0.802 & 1.36 & 2.86 & 26 & 0.388 & 0.988 & 11.2 & -- & -- & -- & -- \\
\hline 07103960 & Trib & -- & -- & -- & -- & 7 & 0.903 & 1.14 & 3.47 & -- & -- & -- & -- \\
\hline 07103970 & Main & 11 & 0.550 & 0.830 & 0.987 & 22 & 0.348 & 0.685 & 0.880 & 21 & 0.367 & 1.00 & 2.58 \\
\hline 07103990 & Trib & -- & -- & -- & -- & 4 & 2.67 & 3.81 & 4.32 & 4 & 1.77 & 2.62 & 3.44 \\
\hline 385124104501301 & Trib & -- & -- & -- & -- & 5 & 0.539 & 0.588 & 0.747 & 1 & 0.667 & 0.667 & 0.667 \\
\hline 07104905 & Main & 10 & 2.20 & 3.20 & 4.47 & 23 & 1.46 & 2.70 & 4.83 & 15 & 1.08 & 2.06 & 4.89 \\
\hline 384909104504401 & Trib & -- & -- & -- & -- & 7 & 0.618 & 1.09 & 4.39 & -- & -- & -- & -- \\
\hline 07105500 & Main & 9 & 2.63 & 3.56 & 5.90 & 19 & 1.53 & 2.29 & 3.73 & 15 & 1.02 & 1.83 & 4.32 \\
\hline 07105530 & Main & 10 & 2.09 & 2.58 & 3.28 & 23 & 1.49 & 2.33 & 3.34 & 20 & 1.18 & 2.00 & 3.56 \\
\hline 07105600 & Trib & -- & -- & -- & -- & 7 & 4.00 & 5.44 & 13.3 & 7 & 1.27 & 2.47 & 3.66 \\
\hline 07105800 & Main & 10 & 2.69 & 3.21 & 3.68 & 24 & 2.05 & 2.58 & 3.75 & 13 & 2.02 & 2.38 & 3.47 \\
\hline \multicolumn{14}{|c|}{ Selenium in filtered water $(\mu \mathrm{g} / \mathrm{L})$} \\
\hline 07103700 & Main & 36 & 0.09 & 0.18 & 0.24 & 35 & 0.08 & 0.15 & 0.43 & 24 & 0.11 & 0.35 & 2.40 \\
\hline 07103707 & Main & 10 & 0.80 & 1.40 & 3.40 & 36 & 0.34 & 0.77 & 6.00 & -- & -- & -- & -- \\
\hline 07103960 & Trib & -- & -- & -- & -- & 7 & 0.72 & 1.20 & 1.80 & -- & -- & -- & -- \\
\hline 07103970 & Main & 11 & 0.65 & 0.90 & 1.20 & 23 & 0.42 & 0.70 & 0.99 & 21 & 0.25 & 0.53 & 0.94 \\
\hline 07103990 & Trib & 2 & 3.40 & 3.55 & 3.70 & 10 & 2.30 & 3.75 & 4.50 & 4 & 0.86 & 1.45 & 1.90 \\
\hline 385124104501301 & Trib & -- & -- & -- & -- & 5 & 0.59 & 0.65 & 0.78 & 1 & 0.78 & 0.78 & 0.78 \\
\hline 07104905 & Main & 34 & 1.80 & 3.30 & 6.60 & 38 & 1.70 & 2.85 & 5.50 & 16 & 0.96 & 1.55 & 3.50 \\
\hline 384909104504401 & Trib & -- & -- & -- & -- & 7 & 0.34 & 1.20 & 5.10 & -- & -- & -- & -- \\
\hline 07105500 & Main & 38 & 1.90 & 3.15 & 6.30 & 44 & 1.40 & 2.40 & 4.80 & 19 & 0.84 & 1.50 & 3.60 \\
\hline 07105530 & Main & 34 & 2.10 & 2.75 & 4.10 & 37 & 1.80 & 2.50 & 3.80 & 23 & 0.79 & 1.50 & 3.00 \\
\hline 07105600 & Trib & 2 & 14.1 & 14.9 & 15.7 & 10 & 4.30 & 11.8 & 17.4 & 3 & 0.67 & 1.20 & 1.80 \\
\hline 07105800 & Main & 35 & 2.40 & 3.30 & 5.60 & 40 & 2.00 & 3.00 & 4.50 & 13 & 1.30 & 1.90 & 3.40 \\
\hline \multicolumn{14}{|c|}{ Zinc in unfiltered water $(\mu \mathrm{g} / \mathrm{L})$} \\
\hline 07103700 & Main & 11 & 2.30 & 4.10 & 9.00 & 22 & 2.30 & 4.85 & 109 & 21 & 2.90 & 311 & 17,200 \\
\hline 07103707 & Main & 7 & 35.4 & 67.4 & 108 & 26 & 18.6 & 53.2 & 6390 & -- & -- & -- & -- \\
\hline 07103960 & Trib & -- & -- & -- & -- & -- & -- & -- & -- & -- & -- & -- & -- \\
\hline 07103970 & Main & 11 & 7.20 & 13.9 & 50.3 & 22 & 3.00 & 6.95 & 20.8 & 21 & 10.6 & 113 & 379 \\
\hline 07103990 & Trib & -- & -- & -- & -- & -- & -- & -- & -- & -- & -- & -- & -- \\
\hline 385124104501301 & Trib & -- & -- & -- & -- & -- & -- & -- & -- & -- & -- & -- & -- \\
\hline 07104905 & Main & 10 & 13.8 & 31.8 & 61.0 & 23 & 11.8 & 26.0 & 52.9 & 15 & 23.9 & 230 & 486 \\
\hline 384909104504401 & Trib & -- & -- & -- & -- & -- & -- & -- & -- & -- & -- & -- & -- \\
\hline 07105500 & Main & 11 & 10.1 & 33.5 & 104 & 22 & 13.4 & 21.8 & 57.8 & 15 & 18.7 & 240 & 1,130 \\
\hline 07105530 & Main & 10 & 35.0 & 44.1 & 60.3 & 23 & 24.1 & 33.8 & 58.7 & 20 & 35.3 & 268 & 875 \\
\hline 07105600 & Trib & -- & -- & -- & -- & 3 & 6.50 & 16.7 & 22.8 & 4 & 164 & 242 & 260 \\
\hline 07105800 & Main & 7 & 29.3 & 35.0 & 44.6 & 16 & 19.8 & 29.0 & 42.8 & 12 & 53.7 & 233 & 728 \\
\hline
\end{tabular}


Table 8. Minimum, median, and maximum concentrations for selected trace elements at sites in the Fountain Creek watershed, Colorado, 2007-2015.-Continued [USGS, U.S. Geological Survey; Main, main-stem site; Trib, tributary site; $\mu \mathrm{g} / \mathrm{L}$, micrograms per liter; N, number of samples; E, estimated value; <, less than the value shown; --, no value]

\begin{tabular}{|c|c|c|c|c|c|c|c|c|c|c|c|c|c|}
\hline \multirow{2}{*}{$\begin{array}{c}\text { USGS } \\
\text { site number }\end{array}$} & \multirow{2}{*}{$\begin{array}{l}\text { Site } \\
\text { type }\end{array}$} & \multicolumn{4}{|c|}{ Cold-season flow } & \multicolumn{4}{|c|}{ Warm-season flow } & \multicolumn{4}{|c|}{ Stormflow } \\
\hline & & $\mathbf{N}$ & Minimum & Median & Maximum & $\mathbf{N}$ & Minimum & Median & Maximum & $\mathbf{N}$ & Minimum & Median & Maximum \\
\hline \multicolumn{14}{|c|}{ Zinc in filtered water $(\mu \mathrm{g} / \mathrm{L})$} \\
\hline 07103700 & Main & 11 & E1.6 & 2.1 & 3.80 & 23 & 1.10 & $<2.0$ & 3.80 & 21 & $<1.4$ & 2.6 & 63.5 \\
\hline 07103707 & Main & 10 & 9.10 & 59.8 & 154 & 36 & $<2.0$ & 11.6 & 269 & -- & -- & -- & -- \\
\hline 07103960 & Trib & -- & -- & -- & -- & -- & -- & -- & -- & -- & -- & -- & -- \\
\hline 07103970 & Main & 11 & 5.70 & 8.90 & 12.9 & 23 & $<1.4$ & 4.10 & 6.90 & 21 & $<1.4$ & 2.9 & 6.00 \\
\hline 07103990 & Trib & -- & -- & -- & -- & -- & -- & -- & -- & -- & -- & -- & -- \\
\hline 385124104501301 & Trib & -- & -- & -- & -- & -- & -- & -- & -- & -- & -- & -- & -- \\
\hline 07104905 & Main & 10 & 5.50 & 27.0 & 36.8 & 24 & 2.5 & 18.8 & 31.5 & 15 & 3.0 & 5.5 & 21.3 \\
\hline 384909104504401 & Trib & -- & -- & -- & -- & -- & -- & -- & -- & -- & -- & -- & -- \\
\hline 07105500 & Main & 11 & 6.40 & 20.9 & 45.1 & 23 & 2.7 & 14.7 & 30.2 & 15 & 1.4 & 5.8 & 19.4 \\
\hline 07105530 & Main & 10 & 36.2 & 42.1 & 63.9 & 24 & 4.6 & 32.7 & 57.3 & 20 & E2.0 & 5.85 & 23.6 \\
\hline 07105600 & Trib & -- & -- & -- & -- & -- & -- & -- & -- & -- & -- & -- & -- \\
\hline 07105800 & Main & 10 & 21.8 & 29.1 & 43.3 & 25 & 3.2 & 19.1 & 39.6 & 13 & 3.1 & 8.90 & 30.5 \\
\hline
\end{tabular}



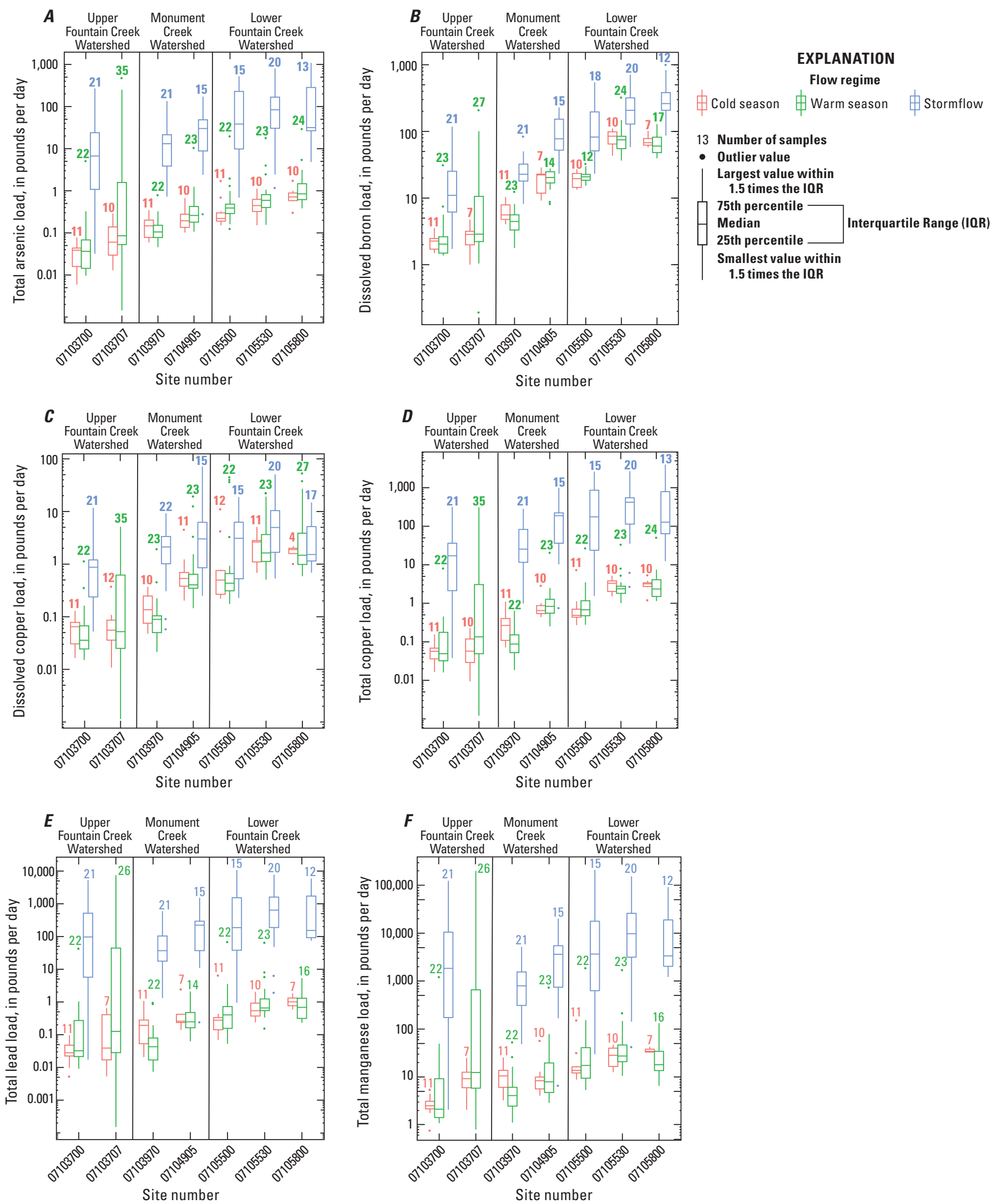

Figure 11. Variations in $A$, total arsenic, $B$, dissolved boron, $C$, dissolved copper, $D$, total copper, $E$, total lead, and $F$, total manganese loads at sites for cold-season flow, warm-season flow, and stormflow in the Fountain and Monument Creek watersheds, Colorado, 2007 through 2015. 

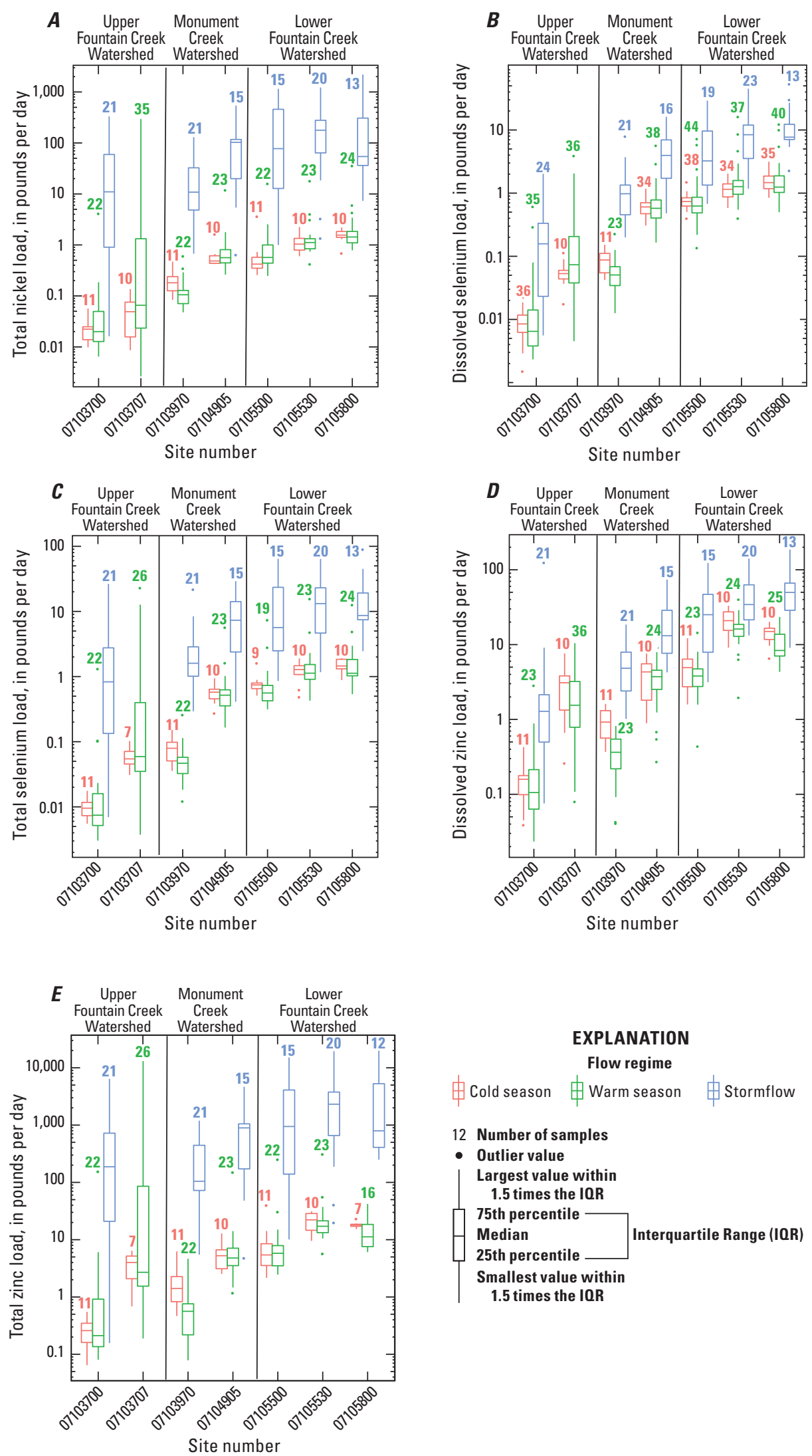

Figure 12. Variations in $A$, total nickel, $B$, dissolved selenium, $C$, total selenium, $D$, dissolved zinc, and $E$, total zinc loads at sites for cold-season flow, warm-season flow, and stormflow in the Fountain and Monument Creek watersheds, Colorado, 2007 through 2015. 
Table 9. Median suspended-sediment concentrations during cold-season flow, warm-season flow, and stormflow in the Fountain and Monument Creek watersheds, Colorado, and $p$-values of Mann-Whitney test of significance of spatial variations in suspended-sediment concentrations.

\begin{tabular}{|c|c|c|c|c|c|c|c|c|c|c|c|}
\hline \multirow{2}{*}{$\begin{array}{c}\text { U.S. } \\
\text { Geological } \\
\text { Survey } \\
\text { site number }\end{array}$} & \multirow{2}{*}{$\begin{array}{c}\text { Median } \\
\text { suspended-sediment } \\
\text { concentrations, } \\
\text { in milligrams per liter }\end{array}$} & \multirow{2}{*}{$\begin{array}{c}\text { Median } \\
\text { rank }\end{array}$} & \multicolumn{9}{|c|}{$\begin{array}{l}\text { Wilcoxon-Mann-Whitney test } p \text {-values } \\
\text { of significance of spatial variations between sites }\end{array}$} \\
\hline & & & 07103700 & 07103707 & 07103970 & 07103990 & 07104905 & 07105500 & 07105530 & 07105600 & 07105800 \\
\hline \multicolumn{12}{|c|}{ Cold-season flow } \\
\hline 07103700 & 9 & 1 & & & & & & & & & \\
\hline 07103707 & 26 & 2 & 0.4145 & & & & & & & & \\
\hline 07103970 & 145 & 5 & & & & & & & & & \\
\hline 07103990 & 394 & 8 & & & 0.0076 & & & & & 0.1041 & \\
\hline 07104905 & 614 & 9 & & & 0.0613 & 0.1149 & & & & & \\
\hline 07105500 & 240 & 7 & & 0.0012 & & & 0.587 & & & & \\
\hline 07105530 & 29 & 3 & & & & & & 0.0000 & & & \\
\hline 07105600 & 202 & 6 & & & & & & & & & 0.1545 \\
\hline 07105800 & 95 & 4 & & & & & & & 0.0000 & & \\
\hline \multicolumn{12}{|c|}{ Warm-season flow } \\
\hline 07103700 & 17 & 1 & & & & & & & & & \\
\hline 07103707 & 24 & 2 & 0.3266 & & & & & & & & \\
\hline 07103970 & 1,480 & 4 & & & & & & & & & \\
\hline 07103990 & 2,375 & 5 & & & 0.0048 & & & & & 0.0176 & \\
\hline 07104905 & 2,960 & 7 & & & 0.0018 & 0.6323 & & & & & \\
\hline 07105500 & 4,170 & 9 & & 0.0000 & & & 0.0004 & & & & \\
\hline 07105530 & 2,490 & 6 & & & & & & 0.0013 & & & \\
\hline 07105600 & 182 & 3 & & & & & & & & & 0.0000 \\
\hline 07105800 & 3,195 & 8 & & & & & & & 0.0030 & & \\
\hline \multicolumn{12}{|c|}{ Stormflow } \\
\hline 07103700 & 3,925 & 7 & & & & & & & & & \\
\hline 07103970 & 1,310 & 1 & & & & & & & & & \\
\hline 07103990 & 8,050 & 8 & & & 0.0000 & & & & & 0.0008 & \\
\hline 07104905 & 2,580 & 3 & & & 0.0011 & 0.0000 & & & & & \\
\hline 07105500 & 2,860 & 4 & & & & & 0.4839 & & & & \\
\hline 07105530 & 2,145 & 2 & & & & & & 0.0214 & & & \\
\hline 07105600 & 3,075 & 6 & & & & & & & & & 0.9132 \\
\hline 07105800 & 3,000 & 5 & & & & & & & 0.0053 & & \\
\hline
\end{tabular}

\section{Specific Conductance, $\mathrm{pH}$, and Dissolved Oxygen}

Median specific-conductance values increased during all flow regimes between main-stem sites 07103970 (MoCr_Woodmen) and 07104905 (MoCr_Bijou) likely because of tributary inflow with higher specific-conductance values. The largest increase occurred during stormflows where median specific-conductance values in Monument Creek increased from 185 to $365 \mu \mathrm{S} / \mathrm{cm}$ (fig. 5). Specific-conductance values measured at Monument Creek tributary sites varied substantially. During warm-season flow conditions, median specific-conductance values ranged from $468 \mu \mathrm{S} / \mathrm{cm}$ at site 07103977 on upper Cottonwood Creek to $2,065 \mu \mathrm{S} / \mathrm{cm}$ at site 07104050 on North Rockrimmon Creek (table 4). The median specific-conductance value (during warm-season flows) at site 07104050 ( $\mathrm{RkCr}$ ) was generally 2 to 5 times higher than the median values at most other Monument Creek tributary sites and about 4 times larger than the median value in Monument Creek at site 07103970 (MoCr_Woodmen).

Median dissolved oxygen concentrations decreased slightly and $\mathrm{pH}$ values increased slightly in Monument Creek between sites 07103970 (MoCr_Woodmen) and 07104905 (MoCr_Bijou). Dissolved oxygen concentrations ranged from 6.3 to $11.6 \mathrm{mg} / \mathrm{L}$ at the main-stem sites and from 5.8 to $11.9 \mathrm{mg} / \mathrm{L}$ at tributary sites. Median $\mathrm{pH}$ values at main-stem sites along Monument Creek ranged from 8.0 to 8.5 and at tributary sites ranged from 7.7 to 8.4 (table 4 ).

\section{Bacteria}

E. coli concentrations were lowest in cold-season flows and highest in stormflows. Median E. coli concentrations increased from 41 to $61 \mathrm{col} / 100 \mathrm{~mL}$ during cold-season flow and from 100 to $390 \mathrm{col} / 100 \mathrm{~mL}$ during warm-season flow (table 5) in the downstream direction between sites 07103970 (MoCr_Woodmen) and 07104905 (MoCr_Bijou). During stormflow, however, median $E$. coli concentrations decreased from 9,200 to $4,600 \mathrm{col} / 100 \mathrm{~mL}$ between the two sites (table 5, fig. 6).

The median E. coli concentration in stormflow samples exceeded the recreational use standard of $126 \mathrm{col} / 100 \mathrm{~mL}$ by more than 73 times at site 07103970 (MoCr_Woodmen) and by more than 36 times at site 07104905 (MoCr_Bijou). E. coli 
Table 10. Median suspended-sediment discharge during cold-season flow, warm-season flow, and stormflow in the Fountain and Monument Creek watersheds, Colorado, and $p$-values of Mann-Whitney test of significance of spatial variations in suspended-sediment discharges.

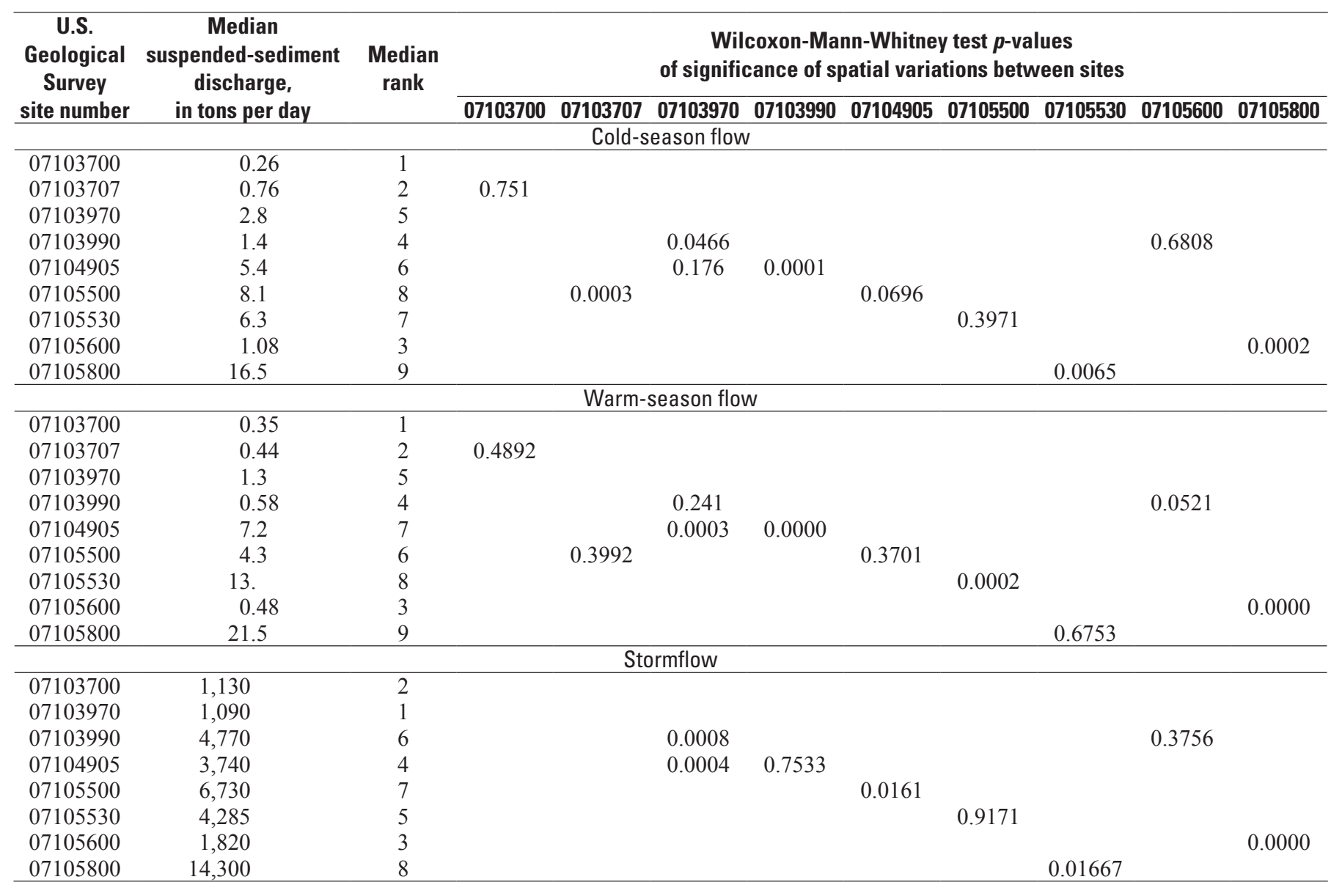

concentrations also exceeded the $126 \mathrm{col} / 100 \mathrm{~mL}$ standard at many tributary sites during periods of warm-season flow and stormflow. Median concentrations at three sites on tributaries to Monument Creek were particularly elevated during warmseason and stormflow conditions: site 385750104475001 (PiCr) on Pine Creek, site 07103977 (upper_CoCr) on Cottonwood Creek, and site 07104050 (RkCr) on North Rockrimmon Creek. Median warm-season concentrations were 610, 1,660, and 1,100 col/100 mL, respectively. The Pine Creek and Cottonwood Creek sites are located in rural areas where cattle and horses are present, and manure may be a possible source of the elevated $E$. coli concentrations. Site 07104050 ( $\mathrm{RkCr}$ ) on North Rockrimmon Creek is urbanized and, based on the few data sampled at this site, it is unclear what may be causing the high $E$. coli concentrations.

At dry weather sample sites in the Monument Creek watershed, E. coli concentrations ranged from less than 1 to greater than 2,400 col/100 mL. The highest concentrations were measured at sites 385640104481501 on South Pine Creek and 385549104451401 on Cottonwood Creek (table 6). Eight of 21 sites had average sample concentrations of $E$. coli that exceeded the recreational use standard of $126 \mathrm{col} / 100 \mathrm{~mL}$ (table 6).

\section{Nutrients}

Dissolved-ammonia concentrations ranged from less than $0.01 \mathrm{mg} / \mathrm{L}$ to $0.69 \mathrm{mg} / \mathrm{L}$, nitrate plus nitrite concentrations ranged from $0.203 \mathrm{mg} / \mathrm{L}$ to $5.52 \mathrm{mg} / \mathrm{L}$, and total phosphorus concentrations ranged from $0.18 \mathrm{mg} / \mathrm{L}$ to $7.62 \mathrm{mg} / \mathrm{L}$ in samples from main-stem sites on Monument Creek (table 7). Concentrations of all three nutrients increased or stayed about the same between the two sites for all three flow conditions (fig. 7 ). The largest downstream increase in median nitrate plus nitrite concentrations between main-stem sites was measured along Monument Creek. During warm-season flow, the median nitrate plus nitrite concentration increased by more than 6 times, from 0.61 to $3.68 \mathrm{mg} / \mathrm{L}$ between sites 07103970 (MoCr_Woodmen) and 07104905 (MoCr_Bijou). The median nitrate plus nitrite concentration doubled between the two sites during cold-season flow and stormflow. All but one tributary that drains into Monument Creek between the two sites had higher median nitrate plus nitrite concentrations than the nearest upstream site on Monument Creek, site 07103970 (MoCr_Woodmen) during warm-season flow and stormflow (table 7 ). During warm-season flows, the median concentration 
Table 11. Median suspended-sediment yield during cold-season, warm-season flow, and stormflow in the Fountain and Monument Creek watersheds, Colorado, and $p$-values of Mann-Whitney test of significance of spatial variations in suspended-sediment yields.

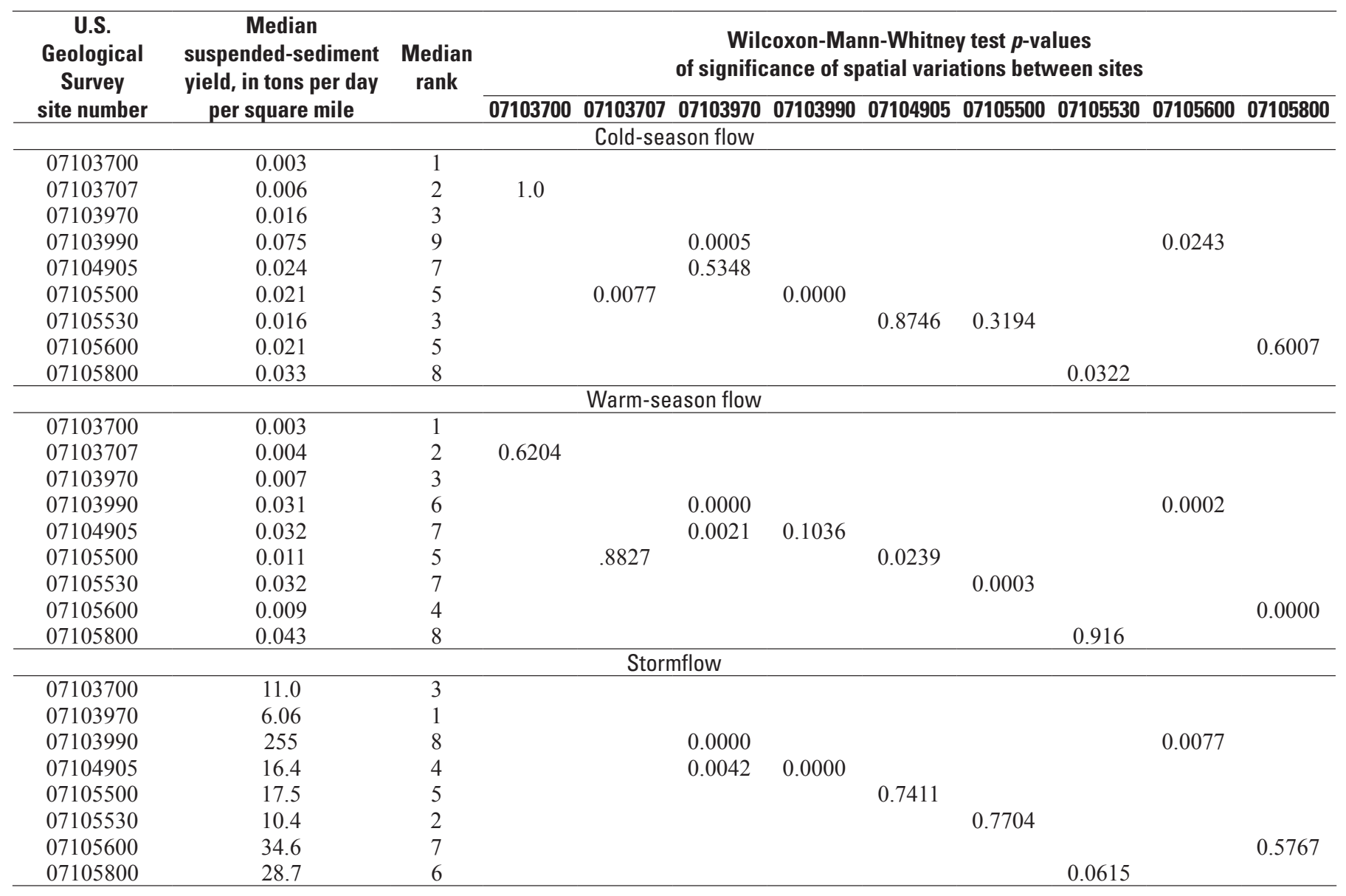

of nitrate plus nitrite was $3.89 \mathrm{mg} / \mathrm{L}$ in Cottonwood Creek at site 07103990 (lower_CoCr) and $8.37 \mathrm{mg} / \mathrm{L}$ in North Rockrimmon Creek at site $07104050(\mathrm{RkCr})$, more than 6 and 13 times larger, respectively, than the median concentration at site 07103970 (MoCr_Woodmen) on Monument Creek (table 7). The J.D. Phillips Water Resource Recovery Facility, that became operational in 2007, discharges water into the stream between the two sites but it is not known how much this discharge contributes to the increase in nutrient concentrations. The in-stream water-quality standard for nitrate plus nitrite is $10 \mathrm{mg} / \mathrm{L}$ (Colorado Department of Public Health and Environment, 2016b). More than 95 percent of samples collected at main-stem sites had concentrations of nitrate plus nitrite less than $5 \mathrm{mg} / \mathrm{L}$. Only one sample at 07104050 (RkCr) during warm-season flow had a concentration of nitrate plus nitrite that exceeded the in-stream water-quality standard of $10 \mathrm{mg} / \mathrm{L}$. Median total phosphorous concentration more than doubled between sites 07103970 (MoCr_Woodmen) and 07104905 (MoCr_Bijou) during stormflow conditions, whereas, during cold-season flows the median concentration of total phosphorus decreased by 3 percent between the sites (table 7, fig. 7).

\section{Nutrient Loads}

Nutrient loads varied by flow regime and location. In Monument Creek at site 07103970 (MoCr_Woodmen), median total phosphorus loads increased from less than $30 \mathrm{lb} / \mathrm{d}$ during warm-season flow to more than 1,460 lb/d during stormflow (fig. 8). Between sites 07103970 (MoCr_Woodmen) and 07104905 (MoCr_Bijou), median nitrate plus nitrite loads in Monument Creek during warm-season flow increased from 52 to $618 \mathrm{lb} / \mathrm{d}$ and during stormflow increased from 750 to $3,340 \mathrm{lb} / \mathrm{d}$. This large increase in nitrate plus nitrite load between the two sites may possibly be attributed to inflow from tributaries and the J.D. Phillips Water Resource Recovery Facility; however, during 2007 through 2015, very few stormflow samples were collected from Monument Creek tributary sites (table 7). Only Cottonwood Creek site 07103990 (lower_CoCr) had enough data to estimate nutrients loads. Based on stormflow data collected at this site during the study, 41 percent of the median nitrate plus nitrite stormflow load at downstream site 07104905 (MoCr_Bijou) originated from Cottonwood Creek. 


\section{Trace Elements}

In Monument Creek, increases in median dissolved boron, dissolved and total copper, total nickel, dissolved and total selenium, and dissolved and total zinc concentrations were measured between sites 07103970 (MoCr_Woodmen) and 07104905 (MoCr_Bijou) during all flow conditions (table 8, figs. 9 and 10). An increase in the median total lead concentration was only measured during warm-season flow and stormflow between the sites (table 8, figs. 9). Median total arsenic and total manganese concentrations decreased during cold-season flow and warm-season flow but increased during stormflow, whereas, median dissolved manganese concentrations decreased during all flow regimes. During cold-season flow, median dissolved manganese concentrations decreased from 54.6 to $14.7 \mathrm{mg} / \mathrm{L}$, whereas median concentrations of dissolved zinc increased from 8.90 to $27.0 \mathrm{mg} / \mathrm{L}$ between the main-stem sites.

Concentrations of dissolved and total selenium varied spatially and by flow regime. Between sites 07103970 (MoCr_Woodmen) and 07104905 (MoCr_Bijou), the median concentration of dissolved selenium during coldseason flow increased from $0.90 \mathrm{mg} / \mathrm{L}$ to $3.30 \mathrm{mg} / \mathrm{L}$, and the median concentration of total selenium increased from $0.83 \mathrm{mg} / \mathrm{L}$ to $3.20 \mathrm{mg} / \mathrm{L}$. Concentrations of dissolved and total selenium were also measured at three tributaries to Monument Creek. These tributaries included Kettle Creek (07103960) which flows from the northeast to the southwest spilling into Monument Creek upstream from site 07103970 (MoCr_Woodmen), Cottonwood Creek (07103990) which flows from east to west spilling into Monument Creek downstream from site 07103970 (MoCr_Woodmen), and Mesa Creek (385124104501301, lower_MeCr) which flows from west to east and spills into Monument Creek upstream from site 07104905 (MoCr_Bijou). In Monument Creek tributaries, median dissolved selenium concentrations during warmseason flow ranged from $0.65 \mathrm{mg} / \mathrm{L}$ at site 385124104501301 (lower_MeCr) to $3.75 \mathrm{mg} / \mathrm{L}$ at site 07103990 (lower_CoCr). Median total selenium concentrations during warm-season flow ranged from $0.59 \mathrm{mg} / \mathrm{L}$ at site 385124104501301 (lower_MeCr) to $3.81 \mathrm{mg} / \mathrm{L}$ at 07103990 (lower_CoCr). Median concentrations of dissolved and total selenium were most often highest at site 07103990 (lower_CoCr) during all flow periods.

\section{Trace-Element Loads}

Instantaneous loads were calculated for Monument Creek sites 07103970 (MoCr_Woodmen) and 07104905 (MoCr_Bijou). Cold-season flow and warm-season flow loads for most dissolved constituents were less than $1 \mathrm{lb} / \mathrm{d}$, but 2 to 8 times larger during stormflow (figs. 11 and 12). Median

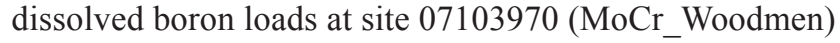
ranged from 4.4 to $5.6 \mathrm{lb} / \mathrm{d}$ during cold-season flow and warm-season flow and were about 4 times larger during stormflow. Loads of total trace elements also increased between cold-season flow, warm-season flow, and stormflow, and at site 07104905 (MoCr_Bijou), depending on the constituent, were 7 to 890 times larger during storm periods. At this site, the median storm load of total lead was $221 \mathrm{lb} / \mathrm{d}$ compared to $0.25 \mathrm{lb} / \mathrm{d}$ or less during cold-season flow and warm-season flow.

Loads of most dissolved and total trace elements increased between sites 07103970 (MoCr_Woodmen) and 07104905 (MoCr_Bijou) during cold-season flow, warmseason flow, and stormflow (figs. 11 and 12). The load increase generally was between 2 and 4 times larger at the downstream site than the upstream site during coldseason flow and warm-season flow but was larger during stormflow, for example, when loads at site 07104905 (MoCr_Bijou) increased by 1.3 to 11.4 times over loads at site 07103970 (MoCr_Woodmen). Only one tributary, 07103960 (lower_Ke), upstream from site 07103970 (MoCr_Woodmen) was sampled for analysis of trace elements and only for dissolved and total selenium during warm-season flow. Dissolved and total selenium loads at 07103960 (lower_Ke) represented about 10 percent of the load at 07103970 (MoCr_Woodmen).

\section{Suspended Sediment}

Suspended-sediment concentrations ranged from 4 to 24,800 $\mathrm{mg} / \mathrm{L}$ at site 07103970 (MoCr_Woodmen) and from 7 to $9,760 \mathrm{mg} / \mathrm{L}$ at site 07104905 (MoCr_Bijou) (table 5). Median suspended-sediment concentrations increased in the downstream direction during cold-season flow, warm-season flow, and stormflow between sites 07103970 (MoCr_Woodmen) and 07104905 (MoCr_Bijou); however, statistically significant increases ( $p$-value less than 0.05 ) were only present during warm-season flow and stormflow (table 9). Increases in suspended-sediment concentrations in Monument Creek between sites 07103970 (MoCr_Woodmen) and 07104905 (MoCr_Bijou) are likely the result of contributions of suspended sediment from intervening tributaries such as the Cottonwood Creek, site 07103990 (lower_CoCr) (table 5). Median suspended-sediment concentrations at site 07103990 (lower_CoCr) were significantly higher than median suspended-sediment concentrations at site 07103970 (MoCr_Woodmen) during all flow regimes (table 9).

\section{Suspended-Sediment Discharge and Yield}

Suspended-sediment discharges varied by site and with flow regime. At site 07103970 (MoCr_Woodmen), median suspended-sediment discharges ranged from 1.3 tons/d during warm-season flow to 1,090 tons/d during stormflow, and at site 07104905 (MoCr_Bijou), median suspendedsediment discharges ranged from 5.4 tons/d during coldseason flow to 3,740 tons/d during stormflow (table 10). During warm-season flow and stormflow, median suspendedsediment discharge was significantly higher at site 07104905 (MoCr_Bijou) than at site 07103970 (MoCr_Woodmen); 
whereas, differences in median suspended-sediment discharge were not significant in cold-season flow (table 10). The median suspended-sediment discharge at Cottonwood Creek site 07103990 (lower_CoCr) was about half of the median suspended-sediment discharge at Monument Creek site 07103970 (MoCr_Woodmen) during cold-season flow but, during stormflow, was almost four times greater.

Suspended-sediment yields increased in the downstream direction in Monument Creek and were substantially higher during stormflow than during cold-season and warm-season flows. At upstream site 07103970 (MoCr_Woodmen), the median suspended-sediment yield was 0.016 tons $/ \mathrm{d} / \mathrm{mi}^{2}$ during cold-season flow and 6.06 tons $/ \mathrm{d} / \mathrm{mi}^{2}$ during stormflow (table 11). The median suspended-sediment yield downstream at site 07104905 (MoCr_Bijou) was 0.024 ton $/ \mathrm{d} / \mathrm{mi}^{2}$ during coldseason flow and 16.4 tons $/ \mathrm{d} / \mathrm{mi}^{2}$ during stormflow (table 11). The median suspended-sediment yield at site 07103970 (MoCr_Woodmen) was more than 860 times larger during stormflow than during warm-season flow.

Variations in suspended-sediment yields were observed between sites 07103970 (MoCr_Woodmen) and 07103990 (lower_CoCr) and between sites 07103990 (lower_CoCr) and 07104905 (MoCr_Bijou) in the Monument Creek watershed during cold-season flow and during stormflow (table 11). Median suspended-sediment yields between sites 07103970 (MoCr_Woodmen) and 07104905 (MoCr_Bijou) showed no significant differences during cold-season flow; however, during warm-season flow and stormflow, median suspendedsediment yields were significantly higher at the downstream site 07104905 (MoCr_Bijou) (table 11). The median suspended-sediment yield at site 07103990 (lower_CoCr) was significantly higher than median suspended-sediment yield at site 07104905 (MoCr_Bijou) during stormflow (table 11). The median suspended-sediment yield at site 07103990 (lower_CoCr) during stormflow (255 tons $/ \mathrm{d} / \mathrm{mi}^{2}$ ) was about an order of magnitude higher than all other sites (table 11). During warm-season flow, site 07103990 (lower_CoCr), a site with the smallest drainage area $\left(18.7 \mathrm{mi}^{2}\right)$ and second smallest streamflow, had suspended-sediment discharges comparable or larger than sites with drainage areas 3 to 10 times larger.

\section{Lower Fountain Creek Watershed}

Water-quality samples were collected during cold-season flows, warm-season flows, and stormflows at main-stem sites 07105500 (FoCr_Nevada), 07105530 (FoCr_Janitell), and 07105800 (FoCr_Security) and during warm-season flows and stormflows at site 07105600 (SaCr) on Sand Creek from 2007 through 2015. In 2015, additional samples for $E$. coli bacteria were collected quarterly during dry weather conditions (described in the Methods of Investigation section of this report) at 18 sites in the Lower Fountain Creek watershed (table 1; fig. 1).

Streamflow generally increases in Lower Fountain Creek in the downstream direction because of inflow from tributaries, discharge from wastewater treatment plants, urban runoff, and irrigation return flow, and these increases vary by flow regime. Based on median instantaneous discharge values at each site (table 4), the median increase in streamflow between sites 07104905 (MoCr_Bijou) and 07105500 (FoCr_Nevada) during warm-season flows was $10 \mathrm{ft}^{3} / \mathrm{s}$ and during cold-season flows, it was $13 \mathrm{ft}^{3} / \mathrm{s}$. Between sites 07105500 (FoCr_Nevada) and 07105530 (FoCr_Janitell), the median increase in streamflow during warm-season flows was $63 \mathrm{ft}^{3} / \mathrm{s}$ and during cold season flows, it was $39 \mathrm{ft}^{3} / \mathrm{s}$ because of discharge from the Las Vegas Street Wastewater Treatment Plant (fig. 1). Sand Creek enters Fountain Creek downstream from site 07105530 (FoCr_Janitell), and although median warm-season inflows to Fountain Creek were small $\left(1.9 \mathrm{ft}^{3} / \mathrm{s}\right)$, median stormflow inflows were about $207 \mathrm{ft}^{3} / \mathrm{s}$, and ranged from 5.5 to more than $3,000 \mathrm{ft}^{3} / \mathrm{s}$. Discharge from Security Wastewater Treatment Plant enters Fountain Creek upstream from site 07105800 (FoCr_Security). Between sites 07105530 (FoCr_Janitell) and 07105800 (FoCr_Security) the median decrease in streamflow during warm-season flows was $23 \mathrm{ft}^{3} / \mathrm{s}$ and during cold season flows, it was $3 \mathrm{ft}^{3} / \mathrm{s}$ (table 4).

\section{Specific Conductance, $\mathrm{pH}$, and Dissolved Oxygen}

Median specific-conductance values increased in Lower Fountain Creek between sites 07105500 (FoCr_Nevada) and 07105800 (FoCr_Security) during cold-season flow and warm-season flow at all main-stem sites but, during stormflow, the median specific-conductance value at 07105530 (FoCr_Janitell) was lower than all the other sites (table 4). Tributary site 07105600 (SaCr) had elevated specificconductance values compared to the main-stem sites. The median specific-conductance value during warm-season flow was $1,115 \mu \mathrm{S} / \mathrm{cm}$ at site $07105600(\mathrm{SaCr})$ compared to $667 \mu \mathrm{S} / \mathrm{cm}$ at upstream site 07105530 (FoCr_Janitell) and $752 \mu \mathrm{S} / \mathrm{cm}$ at downstream site 07105800 (FoCr_Security) on Fountain Creek (figs. 1 and 5; table 4). Although specificconductance values are relatively high in Sand Creek above the mouth compared to specific-conductance values in Fountain Creek, the median discharge measured at this location was only $1.9 \mathrm{ft}^{3} / \mathrm{s}$ during warm-season flow compared to about $110 \mathrm{ft}^{3} / \mathrm{s}$ at Fountain Creek site 07105530 (FoCr_Janitell) upstream from the confluence with Sand Creek. Between Fountain Creek sites 07105530 and 07105800 , the median specific-conductance value increased by about 12 percent during warm-season flows and increased by about 55 percent during stormflows, probably in part because of inflow from Sand Creek (fig.1; table 4).

Values of $\mathrm{pH}$ ranged from 6.7 to 9.0 and were generally lower during stormflows than during cold-season flows and warm-season flows (table 4). All measurements were within the Colorado in-stream water-quality standard range for $\mathrm{pH}$ of 6.5 to 9.0 (Colorado Department of Public Health and Environment, 2016b). 
Dissolved-oxygen concentrations ranged from 5.3 to $11.8 \mathrm{mg} / \mathrm{L}$ in samples (table 4). Median dissolved-oxygen concentrations were higher during cold-season flow conditions. Dissolved-oxygen concentrations generally were greater than $6 \mathrm{mg} / \mathrm{L}$ and concentrations were similar for warm-season flow and stormflow at most sites (table 4). At all main-stem and tributary sites in Fountain Creek, percent saturation of dissolved oxygen generally was larger than 90 percent during all flow conditions, which indicated well-oxygenated streams.

\section{Bacteria}

E. coli concentrations at each site generally differed by a factor of 10 or more during all flow conditions (fig. 6). The lowest concentrations of $E$. coli were measured during cold-season flow and the highest during stormflow. Median E. coli concentrations at main-stem sites during cold-season flow were less than or equal to $100 \mathrm{col} / 100 \mathrm{~mL}$, whereas median $E$. coli concentrations during warm-season flow and stormflow were much larger, ranging between 160 and $440 \mathrm{col} / 100 \mathrm{~mL}$ during warm-season flow and 4,750 and $11,000 \mathrm{col} / 100 \mathrm{~mL}$ during stormflow (table 5). During warmseason flow, median E. coli concentrations decreased in the downstream direction at main-stem sites (table 5). Median E. coli concentrations exceeded the recreational use standard of $126 \mathrm{col} / 100 \mathrm{~mL}$ during warm-season flows and stormflows at all Lower Fountain Creek main-stem sites and at Salt Creek site 07105600 (SaCr). During stormflow, median E. coli concentrations were from 37 to 155 times higher than the recreational use standard. Concentrations of $E$. coli measured at dry weather sites ranged from less than $1 \mathrm{col} / 100 \mathrm{~mL}$ to $8,200 \mathrm{col} / 100 \mathrm{~mL}$ (table 6 ). The highest concentrations were measured in samples from Shooks Run tributary at site 45 (fig. 1; table 1) where concentrations ranged from $130 \mathrm{col} / 100 \mathrm{~mL}$ to $2,800 \mathrm{col} / 100 \mathrm{~mL}$, and Cheyenne Run tributary at site 44 (fig. 1, table 1 ) where concentrations ranged from $550 \mathrm{col} / 100 \mathrm{~mL}$ to $8,200 \mathrm{col} / 100 \mathrm{~mL}$ (table 6).

\section{Nutrients}

At main-stem sites, dissolved-ammonia concentrations measured in samples ranged from less than 0.01 $\mathrm{mg} / \mathrm{L}$ to $0.98 \mathrm{mg} / \mathrm{L}$ (table 7). At Sand Creek site 07105600 ( $\mathrm{SaCr}$ ), dissolved-ammonia concentrations measured in samples ranged from less than 0.01 to $2.65 \mathrm{mg} / \mathrm{L}$ (table 7). Median dissolved-ammonia concentrations were higher in stormflow samples than in warm- and cold-season flow samples at most sites (fig. 7). Between Fountain Creek sites 07105500 (FoCr_Nevada) and 07105530 (FoCr_Janitell), the median warm-season dissolved-ammonia concentration increased from 0.02 to $0.04 \mathrm{mg} / \mathrm{L}$. However, the largest downstream increase in median dissolved-ammonia concentrations occurred between Fountain Creek sites 07105530 (FoCr_Janitell) and 07105800 (FoCr_Security) where the median concentration increased from $0.04 \mathrm{mg} / \mathrm{L}$ to $0.17 \mathrm{mg} / \mathrm{L}$ during warm-season flows. Possible sources of ammonia may be discharge from the Security Wastewater Treatment Plant and inflow from Sand Creek between the two sites.

Median nitrate plus nitrite concentrations during warm-season flow increased from $2.35 \mathrm{mg} / \mathrm{L}$ at site 07105500 (FoCr_Nevada) to $3.66 \mathrm{mg} / \mathrm{L}$ at site 07105800 (FoCr_Security). The largest downstream increase in median nitrate plus nitrite concentrations occurred between main-stem sites 07105500 (FoCr_Nevada) and 07105530 (FoCr_Janitell) on Lower Fountain Creek (fig. 7; table 7). Between the two sites, the median nitrate plus nitrite concentration increased from 2.23 to $3.39 \mathrm{mg} / \mathrm{L}$ during cold-season flow, from 2.35 to $3.37 \mathrm{mg} / \mathrm{L}$ during warm-season flow, and from 0.86 to $1.09 \mathrm{mg} / \mathrm{L}$ percent during stormflow. The relatively large increase in median nitrate plus nitrite concentrations between site 07105500 and 07105530 coincides with the operations of the Las Vegas Street Wastewater Treatment Plant that is located between the two sites. Median nitrate plus nitrite concentrations in Sand Creek at site $07105600(\mathrm{SaCr})$ were lower than median concentrations in Fountain Creek (table 7).

In the Lower Fountain Creek watershed, total phosphorus concentrations measured in samples ranged from $0.026 \mathrm{mg} / \mathrm{L}$ to $13.3 \mathrm{mg} / \mathrm{L}$. Total phosphorus concentrations were higher in samples collected during stormflows than in samples collected during cold-season flow and warm-season flow (fig. 7). Median total phosphorus concentrations were from 2 to 65 times higher in stormflow samples than in warm-season flow samples at main-stem sites. During warm-season flows, median total phosphorus concentrations increased from $0.299 \mathrm{mg} / \mathrm{L}$ at site 07105500 (FoCr_Nevada) to $0.722 \mathrm{mg} / \mathrm{L}$ at site 07105800 (FoCr_Security) in Lower Fountain Creek (fig. 7).

\section{Nutrient Loads}

Increases in nutrient loading were particularly noticeable downstream from the Las Vegas Street Wastewater Treatment Plant, at site 07105530 (FoCr_Janitell). Nutrient loads increased, on average, more than 200 percent during stormflow between sites 07105500 (FoCr_Nevada) and 07105530 (FoCr_Janitell) because streamflow and nutrient concentrations were higher at 07105530 (FoCr_Janitell) than 07105500 (FoCr_Nevada) (fig. 8). The median instantaneous streamflow during stormflow increased by 83 percent between the two sites; the median dissolved ammonia, nitrate plus nitrite, and total phosphorus concentrations increased by 95,27 , and 12 percent, respectively, during stormflow between 07105500 (FoCr_Nevada) and 07105530 (FoCr_Janitell). Median streamflow during stormflow at Sand Creek site $07105600(\mathrm{SaCr})$ was about $207 \mathrm{ft}^{3} / \mathrm{s}$ and ranged from 5.5 to $3,040 \mathrm{ft}^{3} / \mathrm{s}$ (table 4).

\section{Trace Elements}

Trace element concentrations varied by location and flow regime in Lower Fountain Creek. During cold-season flow, median concentrations of dissolved and total arsenic, total manganese, total nickel, and dissolved and total selenium 
decreased between sites 07105500 (FoCr_Nevada) and 07105530 (FoCr_Janitell). Whereas, median concentrations of dissolved boron, dissolved and total copper, total lead, dissolved manganese, and dissolved and total zinc increased between the two sites during cold-season flow. During warmseason flow, median concentrations of dissolved boron, total copper, and dissolved zinc increased by more than 80 percent between the two sites, whereas median concentrations of dissolved and total arsenic, and total manganese decreased by 25 percent or more.

Changes in median concentrations of trace elements in Fountain Creek between sites 07105500 (FoCr_Nevada) and 07105530 (FoCr_Janitell), particularly during coldseason and warm-season flows, are likely affected by wastewater effluent chemistry and volume. For example, during cold-season flow, the median suspended-sediment concentration at site 07105530 (FoCr_Janitell) was almost an order of magnitude lower than the median suspendedsediment concentration in Fountain Creek upstream at site 07105500 (FoCr_Nevada) (table 5). Concentrations of certain total (unfiltered) trace elements, transported in the particulate matter, may have been lower at site 07105530 (FoCr_Janitell) because the wastewater discharge diluted the in-stream concentrations.

During warm-season flow, median concentrations of dissolved and total arsenic, dissolved and total copper, total lead, total nickel, and dissolved and total selenium increased in Fountain Creek between sites 07105530 (FoCr_Janitell) and 07105800 (FoCr_Security). Sand Creek flows into Fountain Creek between sites 07105530 (FoCr_Janitell) and 07105800 (FoCr_Security) and likely contributes to the increase in certain trace element concentrations in Fountain Creek between these sites. At Sand Creek site 07105600 ( $\mathrm{SaCr}$ ), median warm-season flow concentrations of total arsenic, total copper, total lead, total manganese, total nickel, and dissolved and total selenium were greater than concentrations at main-stem sites upstream and downstream from the Sand Creek confluence. During warm-season flow, the median dissolved selenium concentration at Sand Creek site (07105600) was $11.8 \mathrm{mg} / \mathrm{L}$, about 4 times higher than the median concentrations at the surrounding Fountain Creek sites 07105530 and 07105800 .

Water-quality standards for trace elements were only exceeded in two samples in the Lower Fountain Creek watershed. The water-quality standard for total arsenic of $50 \mathrm{mg} / \mathrm{L}$ was exceeded in one stormflow sample at site 07105500 (FoCr_Nevada) and one stormflow sample at site 07105800 (FoCr_Security), both collected on July 7, 2010. The highest median dissolved selenium concentration $(14.9 \mathrm{mg} / \mathrm{L})$ in the Lower Fountain Creek watershed were measured at Sand Creek site 07105600 (SaCr) during cold-season flow (table 8). All dissolved selenium concentrations measured in samples in the Lower Fountain Creek watershed were below the water-quality standard of $18.4 \mathrm{mg} / \mathrm{L}$. Concentrations of dissolved copper and dissolved zinc were below the computed standards.

\section{Trace-Element Loads}

Loads for most dissolved and total trace elements at Fountain Creek sites downstream from the confluence with Monument Creek (figs. 9-12) increased between sites 07105500 (FoCr_Nevada) and 07105530 (FoCr_Janitell) and then decreased between site 07105530 and 07105800 (FoCr_Security). The increase corresponded to the increase in streamflow measured between sites 07105500 (FoCr_Nevada) and 07105530 (FoCr_Janitell), and the decrease corresponded to the decrease in flow between 07105530 and 07105800 (FoCr_Security). The median cold-season flow and warmseason flow at site 07105530 (FoCr_Janitell) was about 2 times larger than at site 07105500 (FoCr_Nevada), and the differences in streamflow between the two sites can be attributed to the Las Vegas Street Wastewater Treatment Plant. The difference, however, in selected trace-element loads was larger than the differences in streamflow between the two sites. During warm-season conditions, the median loads of dissolved boron, total copper, and total zinc were about 3 times larger at site 07105530 (FoCr_Janitell) than at site 07105500 (FoCr_Nevada). Median dissolved zinc loads during warm-season flow increased from 3.8 to $16.2 \mathrm{lb} / \mathrm{d}$ between the two sites, a 326-percent increase that cannot be attributed solely to the increased streamflow. During warm-season flow, median dissolved zinc concentrations increased from 14.7 to $32.7 \mathrm{mg} / \mathrm{L}$ between the sites. Zinc commonly is found in urban runoff, is directly correlated with street traffic volumes (University of Wisconsin-Extension, 1997), and may be contributing to the increase. At site 07105800 (FoCr_Security), the most downstream site for purposes of this report, traceelement loads generally were similar or slightly smaller than at site 07105530 (FoCr_Janitell) during cold-season flow and warm-season flow. Median storm loads were 3.5 to 890 times larger than cold-season flow and warm-season flow loads; total lead and total manganese increased by factors of 225 and 185 , respectively, compared to warm-season flow.

\section{Suspended Sediment}

In Lower Fountain Creek, median suspended-sediment concentrations decreased between sites 07105500 (FoCr_Nevada) and 07105530 (FoCr_Janitell) and increased between sites 07105530 (FoCr_Janitell) and 07105800 (FoCr_Security) during all flow regimes (fig.1; table 5). The highest median suspended-sediment concentrations were measured in stormflow. During stormflow, the median suspendedsediment concentration was $2,860 \mathrm{mg} / \mathrm{L}$ at site 07105500 (FoCr_Nevada), $2,145 \mathrm{mg} / \mathrm{L}$ at site 07105530 (FoCr_Janitell), and $3,000 \mathrm{mg} / \mathrm{L}$ at site 07105800 (FoCr_Security) (table 9). Significant ( $p$-value less than 0.05) increases in median suspended-sediment concentrations were measured during cold-season flow and warm-season flow between Upper Fountain Creek site 07103707 (FoCr_8th) and Lower Fountain Creek site 07105500 (FoCr_Nevada) because of inflows from Monument Creek with higher suspended-sediment 
concentrations (table 5). Median suspended-sediment concentrations between sites 07104905 (MoCr_Bijou) and 07105500 (FoCr_Nevada) increased significantly during warm-season flow but showed no significant differences during cold-season flow and stormflow (table 9). Significant decreases in median suspended-sediment concentrations were measured between sites 07105500 (FoCr_Nevada) and 07105530 (FoCr_Janitell) during all flow regimes.

\section{Suspended-Sediment Discharge and Yield}

Median suspended-sediment discharge ranged from 4.3 to 6,730 tons/d at site 07105500 (FoCr_Nevada), from 6.3 to 4,285 tons/d at site 07105530 (FoCr_Janitell), and from 16.5 to 14,300 tons/d at site 07105800 (FoCr_Security) (table 10). During stormflows, significant increases in median suspended-sediment discharges occurred between 07104905 (MoCr_Bijou) and 07105500 (FoCr_Nevada) and between 07105530 (FoCr_Janitell) and 07105800 (FoCr_Security). Significant increases in median suspendedsediment discharges and median suspended-sediment yield occurred between 07103707 (FoCr_8thSt) and 07105500 (FoCr_Nevada) and between 07105530 (FoCr_Janitell) and 07105800 (FoCr_Security) during cold-season flow and between 07105500 (FoCr_Nevada) and 07105530 (FoCr_Janitell) during warm-season flow. Median suspendedsediment yields at main-stem sites in Lower Fountain Creek were between 325 and 1,590 times larger during stormflow than during warm-season flow.

\section{Summary}

From 2007 through 2015, the U.S. Geological Survey, in cooperation with Colorado Springs City Engineering, conducted a study within the Fountain and Monument Creek watersheds, Colorado, to characterize surface-water quality and suspended sediment for three different streamflow regimes, with an emphasis on characterizing water quality during storm runoff. Data collected during this study were used to evaluate the effects of stormflows and wastewatertreatment effluent discharge on Fountain and Monument Creeks in the Colorado Springs, Colorado, area. Water-quality samples were collected at 2 sites on Upper Fountain Creek, 2 sites on Monument Creek, 3 sites on Lower Fountain Creek, and 13 tributary sites during cold-season flow (NovemberApril), warm-season flow (May-October), and stormflow. During 2015, additional surface-water samples were collected and analyzed for Escherichia coli (E. coli) during dry weather conditions at 41 sites, located in E. coli impaired stream reaches, to help identify source areas and scope of the impairment. Concentrations of E. coli, total arsenic, and dissolved copper, selenium, and zinc in surface-water samples were compared to Colorado acute in-stream standards.

Along Upper Fountain Creek, water quality varied by location and streamflow regime. Post-fire runoff from the recent (June 23, 2012, to July 10, 2012) Waldo Canyon Fire burn area affected surface-water quality and suspended sediment in Fountain Creek, particularly during stormflow conditions. Runoff from urban and suburban areas and Gold Hill Mesa, a tailings pile for a former gold refinery located just upstream from site 07103707 (FoCr_8th), affected surfacewater quality during all flow regimes. Between main-stem sites 07103700 (FoCr_Manitou) and 07103707 (FoCr_8th), specific-conductance values increased in the downstream direction, whereas, dissolved oxygen and $\mathrm{pH}$ values remained relatively constant. For example, the median cold-season flow specific-conductance value increased in the downstream direction from $356 \mu \mathrm{S} / \mathrm{cm}$ at site 07103700 (FoCr_Manitou) to $522 \mu \mathrm{S} / \mathrm{cm}$ at site 07103707 (FoCr_8th). Concentrations of $E$. coli also increased in the downstream direction and were substantially higher in warm-season flow and stormflow samples than in cold-season flow samples at the main-stem sites. During cold-season flow, median E. coli concentrations ranged from 63 colonies per 100 milliliters $(\mathrm{col} / 100 \mathrm{~mL})$ at site 07103700 (FoCr_Manitou) to $80 \mathrm{col} / 100 \mathrm{~mL}$ at site 07103707 (FoCr_8th), whereas, during warm-season flow, median E. coli concentrations at the two sites ranged from 410 to $1,350 \mathrm{col} / 100 \mathrm{~mL}$, respectively. These median warm-season $E$. coli concentrations exceeded the recreational use standard of $126 \mathrm{col} / 100 \mathrm{~mL}$. The median E. coli stormflow concentration of $1,800 \mathrm{col} / 100 \mathrm{~mL}$ at site 07103700 (FoCr_Manitou) was more than 14 times higher than the water-quality standard. Concentrations of $E$. coli measured in two of the four dry weather samples collected at site 385116104523301 (Fountain Creek at South 32nd Street) exceeded the recreational use standard. At site 385108104522001 (Camp Creek at South 31 st Street), E. coli concentrations measured in dry weather samples were well below the water-quality standard. The elevated concentrations of $E$. coli within the Upper Fountain Creek watershed during warm-season flows and stormflows may be because of runoff from urban and suburban areas and areas with domestic livestock, and possibly, input from onsite wastewater treatment systems.

Dissolved-ammonia concentrations ranged from less than 0.01 to 1.67 milligrams $(\mathrm{mg} / \mathrm{L})$, nitrate plus nitrite concentrations ranged from 0.127 to $13.2 \mathrm{mg} / \mathrm{L}$, and total phosphorus concentrations ranged from less than 0.02 to $71.3 \mathrm{mg} / \mathrm{L}$ in samples from main-stem sites on Upper Fountain Creek. Runoff from the Waldo Canyon fire burn area appeared to increase nutrient concentrations in some warm-season flow and stormflow samples in Upper Fountain Creek after June 2012. The maximum concentrations of dissolved ammonia $(1.67 \mathrm{mg} / \mathrm{L})$, nitrate plus nitrite $(13.2 \mathrm{mg} / \mathrm{L})$, and total phosphorus $(71.3 \mathrm{mg} / \mathrm{L})$ were measured in a single stormflow sample collected July 1, 2013. Instantaneous nutrient loads in stormflow were considerably larger than cold-season flow and warm-season flow loads. At site 07103700 (FoCr_Manitou), median dissolved-ammonia loads ranged from about 0.6 pounds per day $(\mathrm{lb} / \mathrm{d})$ during warm-season flow to about $44 \mathrm{lb} / \mathrm{d}$ during stormflow, median total phosphorus loads ranged from less than $2.0 \mathrm{lb} / \mathrm{d}$ during 
warm-season flow to $1,560 \mathrm{lb} / \mathrm{d}$ during stormflow, and median nitrate plus nitrite loads ranged from $33 \mathrm{lb} / \mathrm{d}$ during warmseason flow to $288 \mathrm{lb} / \mathrm{d}$ during stormflow.

Increases in median total arsenic, total copper, total lead, dissolved and total manganese, total nickel, dissolved and total selenium, and dissolved and total zinc concentrations were measured during cold-season and warm-season flows in Upper Fountain Creek between sites 07103700 (FoCr_Manitou) and 07103707 (FoCr_8th). Dissolved and total manganese, dissolved and total selenium, and dissolved and total zinc concentrations increased the most between the two sites and the largest increases occurred during cold-season flow when streamflow was low and predominantly from groundwater sources. During cold-season flows, in particular, the likely source of these metals is input from the Gold Hill Mesa area between the two sites.

The water-quality standard for total arsenic of $50 \mu \mathrm{g} / \mathrm{L}$ was exceeded in three samples collected during warmseason flows at site 07103707 (FoCr_8th), and in three samples collected during stormflows at site 07103700 (FoCr_Manitou), but not during cold-season flows. Concentrations of dissolved copper, selenium, and zinc measured in samples were below the water-quality standard. As with maximum nutrient concentrations, the maximum concentrations of dissolved and total arsenic, dissolved boron, total lead, total manganese, total nickel, dissolved and total selenium, and total zinc concentrations were measured in a single stormflow sample collected on July 1, 2013, after the Waldo Canyon fire. Median cold-season flow and warm-season flow loads of dissolved arsenic, boron, copper, and selenium were less than $5 \mathrm{lb} / \mathrm{d}$ compared to stormflow loads that ranged from 4 to 24 times larger.

Suspended-sediment concentrations in Upper Fountain Creek ranged from 2 to $155,000 \mathrm{mg} / \mathrm{L}$ in samples collected at site 07103700 (FoCr_Manitou) and from 1 to $51,300 \mathrm{mg} / \mathrm{L}$ at site 07103707 (FoCr_ 8th). The highest suspendedsediment concentrations were measured in stormflow samples collected after the Waldo Canyon fire, with the maximum concentration of $155,000 \mathrm{mg} / \mathrm{L}$ being measured at site 07103700 (FoCr_Manitou) in the first stormflow sample collected after the Waldo Canyon fire on July 1, 2013. The maximum concentrations of dissolved ammonia, nitrate plus nitrite, total phosphorus, dissolved and total arsenic, dissolved boron, total lead, total manganese, total nickel, dissolved and total selenium, and total zinc were also measured in this same sample.

In the Monument Creek watershed, water quality varied by location and streamflow regime. Based on the median instantaneous discharge values at each site, Monument Creek gained about 16.5 cubic feet per second $\left(\mathrm{ft}^{3} / \mathrm{s}\right)$ of streamflow during cold-season flows and $21.0 \mathrm{ft}^{3} / \mathrm{s}$ during warm-season flows between sites 07103970 (MoCr_Woodmen) and 07104905 (MoCr_Bijou). Much of this increase in streamflow can be attributed to the many tributaries that drain into Monument Creek between the two sites and inflow from the J.D. Phillips Water Resource Recovery Facility. Median specific-conductance values increased during all flow regimes between main-stem sites 07103970 (MoCr_Woodmen) and 07104905 (MoCr_Bijou) likely because of tributary inflow with higher specific-conductance values. During warm-season flow conditions, the median specific-conductance values at tributary sites 07103990 on Cottonwood Creek and 07104050 on North Rockrimmon Creek were about 1.5 to 4 times larger, respectively, than the median value in Monument Creek at the nearest upstream main-stem site 07103970 (MoCr_Woodmen).

Between Monument Creek sites 07103970 (MoCr_Woodmen) and 07104905 (MoCr_Bijou), median E. coli concentrations increased from 41 to $61 \mathrm{col} / 100$ $\mathrm{mL}$ during cold-season flow and increased from 100 to $390 \mathrm{col} / 100 \mathrm{~mL}$ during warm-season flow. During stormflow, however, median E. coli concentrations decreased in the downstream direction from 9,200 to $4,600 \mathrm{col} / 100$ $\mathrm{mL}$ between the two sites. The median $E$. coli concentration in stormflow samples exceeded the recreational use standard of $126 \mathrm{col} / 100 \mathrm{~mL}$ by more than 73 times at site 07103970 (MoCr_Woodmen) and by more than 36 times at site 07104905 (MoCr_Bijou). E. coli concentrations also exceeded the $126 \mathrm{col} / 100 \mathrm{~mL}$ standard at tributary sites during periods of stormflow. It is unclear what may be causing the high E. coli concentrations.

Nitrate plus nitrite concentrations and loads increased in Monument Creek in the downstream direction. The largest downstream increase in median nitrate plus nitrite concentrations between main-stem sites was measured along Monument Creek. During warm-season flow, the median nitrate plus nitrite concentration increased by more than 6 times, from 0.61 to $3.68 \mathrm{mg} / \mathrm{L}$ between sites 07103970 (MoCr_Woodmen) and 07104905 (MoCr_Bijou). The median nitrate plus nitrite concentration doubled between the two sites during coldseason flow and stormflow. All but one tributary that drain into Monument Creek between the two sites had higher median nitrate plus nitrite concentrations than the nearest upstream site on Monument Creek, site 07103970 (MoCr_Woodmen). During warm-season flows, the median concentration of nitrate plus nitrite was $3.89 \mathrm{mg} / \mathrm{L}$ in Cottonwood Creek at site 07103990 (lower_CoCr) and $8.37 \mathrm{mg} / \mathrm{L}$ in North Rockrimmon Creek at site 07104050 (RkCr), more than 6 and 13 times larger, respectively, than the median concentration at site 07103970 (MoCr_Woodmen) on Monument Creek. Only one sample collected at 07104050 ( $\mathrm{RkCr}$ ) during warm-season flow had a concentration of nitrate plus nitrite that exceeded the instream water-quality standard of $10 \mathrm{mg} / \mathrm{L}$. Between sites 07103970 (MoCr_Woodmen) and 07104905 (MoCr_Bijou), median nitrate plus nitrite loads during warm-season flow increased from $52 \mathrm{lb} / \mathrm{d}$ to $618 \mathrm{lb} / \mathrm{d}$ and during stormflow increased from $750 \mathrm{lb} / \mathrm{d}$ to $3,340 \mathrm{lb} / \mathrm{d}$.

Increases in median dissolved boron, dissolved and total copper, total nickel, dissolved and total selenium, and dissolved and total zinc concentrations were measured between main-stem sites 07103970 (MoCr_Woodmen) and 07104905 (MoCr_Bijou) during all flow conditions. Median dissolved manganese concentrations decreased between the 
two sites during all flow regimes, whereas, median total manganese and median total arsenic concentrations decreased during cold-season flow and warm-season flow but increased during stormflow.

Median suspended-sediment concentrations and median suspended-sediment loads increased in the downstream direction during all streamflow regimes between mainstem sites 07103970 (MoCr_Woodmen) and 07104905 (MoCr_Bijou); however, statistically significant increases ( $p$-value less than 0.05 ) were only present during warmseason flow and stormflow. These downstream increases in suspended-sediment concentrations and loads in Monument Creek are likely the result of contributions of suspended sediment from intervening tributaries such as the Cottonwood Creek. Median suspended-sediment concentrations at site 07103990 (lower_CoCr) were significantly higher than median suspended-sediment concentrations at site 07103970 (MoCr_Woodmen) during all flow regimes.

In the Lower Fountain Creek watershed, water quality varied by location and streamflow regime. Streamflow generally increases in Lower Fountain Creek in the downstream direction because of inflow from tributaries, discharge from wastewater treatment plants, urban runoff, and irrigation return flow, and these increases vary by flow regime. Median specific-conductance values increased in Lower Fountain Creek between sites 07105500 (FoCr_Nevada) and 07105800 (FoCr_Security) during cold-season flow and warm-season flow at all main-stem sites but, during stormflow, the median specific-conductance value at 07105530 (FoCr_Janitell) was lower than all the other sites. Tributary site 07105600 ( $\mathrm{SaCr}$ ) had elevated specific-conductance values, particularly during cold-season and warm-season flows, compared to the main-stem sites.

Concentrations of $E$. coli varied by streamflow regime and site location. Median E. coli concentrations were less than or equal to $100 \mathrm{col} / 100 \mathrm{~mL}$ during cold-season flow, whereas, during stormflow, median concentrations at sites ranged from 4,750 to $11,000 \mathrm{col} / 100 \mathrm{~mL}$. During warm-season flow, the highest median E. coli concentration in Lower Fountain Creek was measured at site 07105500 (FoCr_Nevada), and median E. coli concentrations decreased in the downstream direction at main-stem sites. Based on median E. coli concentrations, the recreational use standard of $126 \mathrm{col} / 100 \mathrm{~mL}$ was exceeded during warm-season flows and stormflows at all Lower Fountain Creek main-stem sites and at Salt Creek site 07105600 (SaCr). Concentrations of $E$. coli measured at dry weather sites ranged from less than $1 \mathrm{col} / 100 \mathrm{~mL}$ to $8,200 \mathrm{col} / 100 \mathrm{~mL}$. The highest concentrations were measured in samples from Shooks Run tributary and Cheyenne Run tributary.

Dissolved-ammonia, dissolved-nitrate plus nitrite, and total phosphorus concentrations varied with flow regime and location in the Lower Fountain Creek watershed. At mainstem sites, dissolved-ammonia concentrations measured in samples ranged from $0.01 \mathrm{mg} / \mathrm{L}$ to $0.98 \mathrm{mg} / \mathrm{L}$. Median dissolved-ammonia concentrations were higher in stormflow samples than in warm-season flow and cold-season flow samples at most sites. Median concentrations of dissolved nitrate plus nitrite were higher in cold-season flow and warm-season flow samples than in stormflow samples and increased in the downstream direction. For example, between sites 07105500 (FoCr_Nevada) and 07105530 (FoCr_Janitell), the median nitrate plus nitrite concentration increased from 2.23 to $3.39 \mathrm{mg} / \mathrm{L}$ during cold-season flow, from 2.35 to $3.37 \mathrm{mg} / \mathrm{L}$ during warm-season flow, and from 0.86 to $1.09 \mathrm{mg} / \mathrm{L}$ during stormflow. Total phosphorus concentrations in samples ranged from $0.026 \mathrm{mg} / \mathrm{L}$ to $13.3 \mathrm{mg} / \mathrm{L}$. Median total phosphorus concentrations were from 2 to 65 times higher in stormflow samples than in warm-season flow samples at main-stem sites.

Nutrient loads increased, on average, more than 200 percent during stormflows between sites 07105500 (FoCr_Nevada) and 07105530 (FoCr_Janitell) because streamflow and nutrient concentrations were higher at 07105530 (FoCr_Janitell) than 07105500 (FoCr_Nevada). The median instantaneous streamflow during stormflow increased by 82 percent between the two sites; the median dissolved ammonia, nitrate plus nitrite, and total phosphorus concentrations increased by 95,27 , and 12 percent, respectively, during stormflow between 07105500 (FoCr_Nevada) and 07105530 (FoCr_Janitell).

Trace element concentrations varied by location and flow regime in Lower Fountain Creek. During cold-season flow, median concentrations of dissolved and total arsenic, total manganese, total nickel, and dissolved and total selenium decreased between sites 07105500 (FoCr_Nevada) and 07105530 (FoCr_Janitell), whereas median concentrations of dissolved boron, dissolved and total copper, total lead, dissolved manganese, and dissolved and total zinc increased between the two sites. Changes in trace element concentrations in Fountain Creek between sites 07105500 (FoCr_Nevada) and 07105530 (FoCr_Janitell), particularly during cold-season and warm-season flows, are likely affected by wastewater effluent chemistry and volume. Sand Creek flows into Fountain Creek between main-stem sites 07105530 (FoCr_Janitell) and 07105800 (FoCr_Security) and likely effects trace element concentrations in Fountain Creek during certain flow conditions. At Sand Creek site 07105600 ( $\mathrm{SaCr}$ ), median warm-season flow concentrations of total arsenic, total copper, total lead, total manganese, total nickel, and dissolved and total selenium were greater than concentrations at main-stem sites upstream and downstream from the Sand Creek confluence.

In Lower Fountain Creek, median suspended-sediment concentrations decreased between sites 07105500 (FoCr_Nevada) and 07105530 (FoCr_Janitell) and increased between sites 07105530 (FoCr_Janitell) and 07105800 (FoCr_Security) during all flow regimes. Significant increases in median suspended-sediment concentrations were measured during cold-season flow and warm-season flow between Upper Fountain Creek site 07103707 (FoCr_8th) and Lower Fountain Creek site 07105500 (FoCr_Nevada) because of inflows from Monument Creek with higher 
suspended-sediment concentrations. Median suspended-sediment concentrations between sites 07104905 (MoCr_Bijou) and 07105500 (FoCr_Nevada) increased significantly during warm-season flow but showed no significant differences during cold-season flow and stormflow. Significant decreases in median suspended-sediment concentrations were measured between sites 07105500 (FoCr_Nevada) and 07105530 (FoCr_Janitell) during all flow regimes.

Median suspended-sediment discharge ranged from 4.3 to 6,730 tons/d at site 07105500 (FoCr_Nevada), from 6.3 to 4,285 tons/d at site 07105530 (FoCr_Janitell), and from 16.5 to 14,300 tons/d at site 07105800 (FoCr_Security). During stormflows, significant increases in median suspended-sediment discharges occurred between 07104905 (MoCr_Bijou) and 07105500 (FoCr_Nevada) and between 07105530 (FoCr_Janitell) and 07105800 (FoCr_Security). Significant increases in median suspendedsediment discharges and median suspended-sediment yield occurred between 07103707 (FoCr_8thSt) and 07105500 (FoCr_Nevada) and between 07105530 (FoCr_Janitell) and 07105800 (FoCr_Security) during cold-season flow and between 07105500 (FoCr_Nevada) and 07105530 (FoCr_Janitell) during warm-season flow.

\section{References Cited}

Childress, C.J.O., Foreman, W.T., Connor, B.F., and Maloney, T.J., 1999, New reporting procedures based on long-term method detection levels and some considerations for interpretations of water-quality data provided by the U.S. Geological Survey National Water Quality Laboratory: U.S. Geological Survey Open-File Report 99-193, 19 p.

City of Colorado Springs, 2013, Waldo Canyon Fire, 23 June 2010 to 10 July 2012, City of Colorado Springs Final After Action Report, 111 p., accessed March 13, 2017, at http:// www.springsgov.com/units/communications/Colorado SpringsFinalWaldoAAR_3April2013.pdf.

Colorado Department of Local Affairs, 2017a, Historical census data - Counties and municipalities: Colorado Department of Local Affairs web page accessed March 30, 2017, at https://demography.dola.colorado.gov/population/ data/historical_census/.

Colorado Department of Local Affairs, 2017b, Population totals for Colorado and sub-state regions: Colorado Department of Local Affairs web page accessed March 30, 2017, at https://demography.dola.colorado.gov/population/ population-totals-colorado-substate/.
Colorado Department of Local Affairs, 2017c, Population totals for Colorado municipalities: Colorado Department of Local Affairs web page accessed March 30, 2017, at https:// demography.dola.colorado.gov/population/populationtotals-municipalities/.

Colorado Department of Public Health and Environment, 2016a, Regulation no. 31, The basic standards and methodologies for surface water: Colorado Department of Public Health and Environment web page, accessed June 5, 2017, at https://www.colorado.gov/pacific/sites/default/ files/31_2017-03.pdf.

Colorado Department of Public Health and Environment, 2016b, Regulation no. 32, Classifications and numeric standards for Arkansas River Basin: Colorado Department of Public Health and Environment, web page, accessed July 21, 2017, at https://www.colorado.gov/pacific/sites/ default/files/32_2017\%2806\%29.pdf.

Colorado Department of Public Health and Environment, 2016c, Regulation no. 93, Colorado's section 303(d) list of impaired waters and monitoring and evaluation list: Colorado Department of Public Health and Environment web page, accessed June 7, 2017, at https://www.colorado. gov/pacific/sites/default/files/93_2016\%2811\%29.pdf.

Colorado Geological Survey, 2003, Ground water atlas of Colorado: Colorado Geological Survey web page accessed November 30, 2016, at http://coloradogeologicalsurvey.org/ water/groundwater-atlas/.

Edelmann, Patrick, Ferguson, S.A., Stogner, R.W., Sr., August, M., Payne, W.F., and Bruce, J.F., 2002, Evaluation of water quality, suspended sediment, and stream morphology with an emphasis on effects of stormflow on Fountain and Monument Creek basins, Colorado Springs and vicinity, Colorado, 1981 through 2001: U.S. Geological Survey Water-Resources Investigations Report 2002-4104, 59 p.

Edwards, T.K., and Glysson, G.D., 1988, Field methods for measurement of fluvial sediment: U.S. Geological Survey Open-File Report 86-531, 117 p.

El Paso County Public Health, 2017, On-site wastewater treatment systems: El Paso County Health web page, accessed March 30, 2017, at http://www.elpasocountyhealth.org/ services/site-wastewater-treatment-systems.

Fishman, M.J., and Friedman, L.C., 1989, Methods for determination of inorganic substances in water and fluvial sediments: U.S. Geological Survey Techniques of WaterResources Investigations, book 5, chap. A1, 545 p.

Guy, H.P., 1969, Laboratory theory and methods for sediment analysis: U.S. Geological Survey Techniques of WaterResources Investigations, book 5, chap. C1, 58 p. 
Hansen, W.R., and Crosby, E.J., 1982, Environmental geology of the Front Range urban corridor and vicinity, Colorado with a specific section on Physical properties and performance characteristics of surficial deposits and rock units in the greater Denver area by R.R. Shroba: U.S. Geological Survey Professional Paper 1230, 99 p.

Helsel, D.R., and Hirsch, R.M., 1992 Statistical methods in water resources: New York, Elsevier Science Publishing Company Inc., $522 \mathrm{p}$.

Horowitz, A.J., Demas, C.R., Fitzgerald, K.K., Miller, T.L., and Rickert, D.A., 1994, U.S. Geological Survey protocol for the collection and processing of surface-water samples for the subsequent determination of inorganic constituents in filtered water: U.S. Geological Survey Open-File Report 94-539, $57 \mathrm{p}$.

Koltun, G.F., Eberle, M., Gray, J.R., Glysson, G.D., 2006, User's manual for the Graphical Constituent Loading Analysis System (GCLAS): U.S. Geological Survey Techniques and Methods, book 4, chap. C1, 51 p.

Larsen, L.S., 1981, Soil survey of El Paso County area, Colorado: Washington D.C., U.S. Department of Agriculture, Soil Conservation Service, 212 p.

Mau, D.P., Stogner, R.W., Sr., and Edelmann, Patrick, 2007, Characterization of stormflows and wastewater treatmentplant discharges on water quality, suspended sediment, and stream morphology for Fountain and Monument Creek watersheds, Colorado, 1981-2006: U.S. Geological Survey Scientific Investigations Report 2007-5104, 76 p.

Moody, J.A. and Martin, D.A., 2001.Initial hydrologic and geomorphic response following a wildfire in the Colorado Front Range: Earth Surface Processes and Landforms, v. 26, no. 10 , p. $1049-1070$.

Philips, D., 2017, The $\$ 305$ million pile: The Gazette, accessed March 15, 2017, at http://gazette.com.

R Core Team, 2016, R: A language and environment for statistical computing: Vienna, Austria, R Foundation for Statistical Computing, ISBN 3-900051-07-0, available online at http://www.R-project.org/.

Rantz, S.E., and others, 1982, Measurements and computation of streamflow, volumes 1 and 2: U.S. Geological Survey Water-Supply Paper 2175, $631 \mathrm{p}$.

Smith, H.G., Sheridan, G.J., Lane, P., Nyman, P., Haydon, S., 2011, Wildfire effects on water quality in forest catchments: a review with implications for water supply: Journal of Hydrology, v. 396, issues 1-2, p. 170-192, accessed March 15, 2017, https://doi.org/10.1016/j.jhydrol.2010.10.043.
State of New Mexico Environment Department, 2017, Wildfire impacts on surface water quality: State of New Mexico Environment Department, web page accessed March 15, 2017, at https://www.env.nm.gov/swqb/Wildfire/.

University of Wisconsin-Extension, 1997, Polluted urban runoff-A source of concern: University of WisconsinExtension, web page, accessed June 12, 2017, at https:// slide.world/view/lKr7btkHApYJ/1.

U.S. Climate Data, 2017, Climate Colorado SpringsColorado, web page, accessed July 27, 2017, at http://www. usclimatedata.com/climate/colorado-springs/colorado/ united-states/usco0078.

U.S. Environmental Protection Agency, 1986, Ambient water quality criteria for bacteria-1986: Washington, D.C., U.S. Environmental Protection Agency, Office of Water Regulations and Standards, EPA/440/5-84-002, Office of Water Regulations and Standards, $18 \mathrm{p}$.

U.S. Environmental Protection Agency 2004, Monitoring and assessing water quality, chapter 5.11, fecal bacteria: U.S. Environmental Protection Agency, web page, accessed March 12, 2007, at http://www.epa.gov/OWOW/ monitoring/volunteer/stream/vms511.html.

U.S. Geological Survey, 1977, National handbook of recommended methods for water-data acquisition: Reston, Va., U.S. Geological Survey monograph, Office of Water Data Coordination, various pagination.

von Guerard, Paul, 1989a, Suspended sediment and sedimentsource areas in the Fountain Creek drainage basin upstream from Widefield, southeastern Colorado: U.S. Geological Survey Water-Resources Investigations Report 88-4136, $36 \mathrm{p}$.

von Guerard, Paul, 1989b, Sediment-transport characteristics and effects of sediment transport on benthic invertebrates in the Fountain Creek drainage basin upstream from Widefield, southeastern Colorado 1985-88: U.S. Geological Survey Water-Resources Investigations Report 89-4161, 133 p.

Wahl, K.L., and Wahl, T.L., 1995, Determining the flow of Comal Springs at New Braunfels, Texas: Texas Water 95, American Society of Civil Engineers, August 16-17, 1995, San Antonio, Texas, p. 77-86.

Wilde, F.D., ed., 2004, Cleaning of equipment for water sampling (ver. 2.0): U.S. Geological Survey Techniques of Water-Resources Investigations, book 9, chap. A3, accessed March 6, 2017, at http://pubs.water.usgs.gov/twri9A3/.

Wilde, F.D., Radtke, D.B., Gibs, J., and Iwatsubo, R.T., eds., 1998, National field manual for collection of water-quality data: U.S. Geological Survey Techniques of Water-Resources Investigations, book 9, chap. A6, various pagination. 

Publishing support provided by:

Denver Publishing Service Center

For more information concerning this publication, contact: Director, USGS Colorado Water Science Center

Box 25046, Mail Stop 415

Denver, CO 80225

(303) 236-4882

Or visit the Colorado Water Science Center website at: https://co.water.usgs.gov/ 

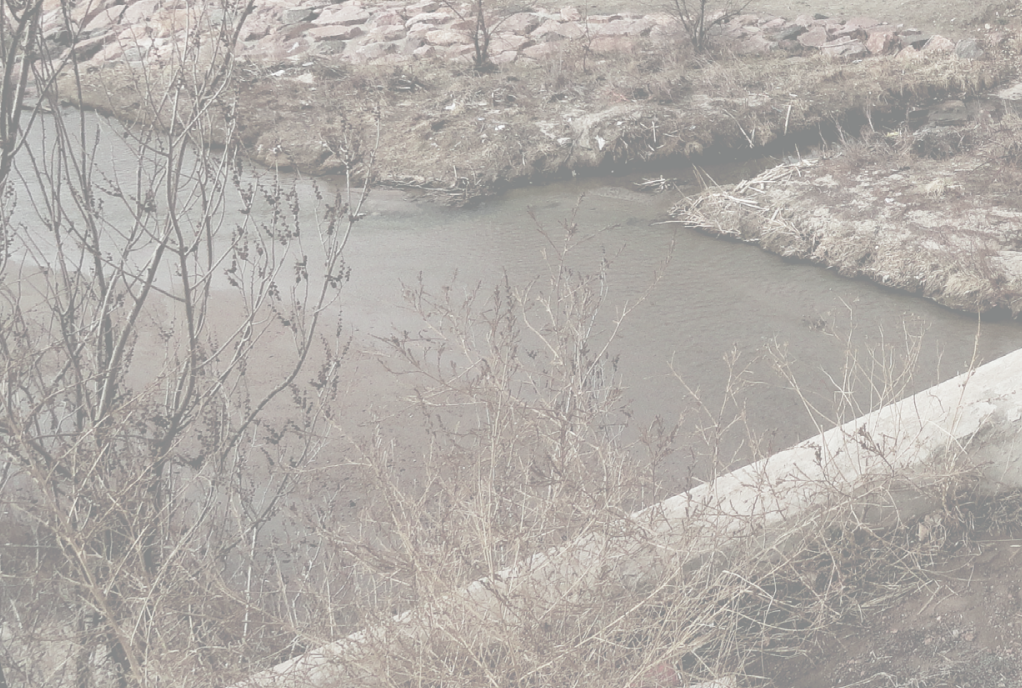